Portland State University

PDXScholar

Fall 12-6-2019

\title{
"An Idolatry of Sound" : Nature, the Natural, and the Castrato's Body in the Eighteenth Century
}

Caitlin Elizabeth Pala

Portland State University

Follow this and additional works at: https://pdxscholar.library.pdx.edu/open_access_etds

Part of the History Commons

Let us know how access to this document benefits you.

\section{Recommended Citation}

Pala, Caitlin Elizabeth, "'An Idolatry of Sound" : Nature, the Natural, and the Castrato's Body in the Eighteenth Century" (2019). Dissertations and Theses. Paper 5341.

https://doi.org/10.15760/etd.7214

This Thesis is brought to you for free and open access. It has been accepted for inclusion in Dissertations and Theses by an authorized administrator of PDXScholar. Please contact us if we can make this document more accessible: pdxscholar@pdx.edu. 
"An Idolatry of Sound":

Nature, the Natural, and the Castrato's Body in the Eighteenth Century

by

Caitlin Elizabeth Pala

A thesis submitted in partial fulfillment of the requirements for the degree of

Masters of Arts

in

History

Thesis Committee:

Richard Beyler, Chair

John Ott

Thomas Luckett

Jelena Simonovic Schiff

Portland State University

2019 
(C) 2019 Caitlin Elizabeth Pala 


\begin{abstract}
The castrati-Italian men castrated before puberty in order to retain their high singing voice-were Europe's first superstars, reaching the height of their popularity in the first few decades of the eighteenth century. While only a tiny percentage of the European population, the castrati embodied many of the significant medical and philosophical questions of the Enlightenment that aimed to understand humanity: human emotion, physiology, sexuality, and culture. As a part of the ongoing debate over what was 'natural,' the castrati hold an interesting place. At the broadest level, the very existence of the castrati asked what it was to be a human being, being a human.

Created purely for the sake of making beautiful music, the castrati were not only abnormal but unnatural in the strictest sense of the word. That said, each castrato as part of his species had a particular set of characteristics that were natural to him. Because of this ontological ambiguity, references to the castrated body appeared in many Enlightenment texts concerning human generation, sexuality, and the nature of vital fluids as a counterexample to the natural male body.
\end{abstract}

As their own 'monstrous' species, the castrati shed light on racial taxonomization and dis/ability classifications. Their role in one of the great art forms of the eighteenth century, opera, placed the castrati at the center of moral debates surrounding verisimilitude and artificiality in aesthetics, and the corruptions and pleasures of sensibility. Lastly, the castrati were intimately connected to medico-moral texts on human sexuality as embodiments of the physical and social dangers associated with sexual deviance. By closely examining the controversy that often surrounded the castrati, 
historians can explore the attitudes towards this 'unnatural' human body within the context of broader socio-scientific debates over racial and cultural variety, sensibility, aesthetics, and the roles of pleasure and utility in Enlightenment discourse. 
Table of Contents

Abstract $\quad$ i

Introduction

Tea with Farinelli

Chapter One

Human, Body and Soul: The Science of Man in the Eighteenth Century

Chapter Two

Of Monsters and Men: $(\mathrm{Hu})$ men on the Margins

Chapter Three

Music and Sensibilité in the Enlightenment: The Sciences de l'homme go to the Opera 75

Chapter Four

"Luxuriancies of Sound": Castrati and the Discourse of Pleasure

Conclusion

The Embodiment of an Era

Primary Bibliography

Secondary Bibliography 
Introduction

Tea with Farinelli

On Saturday, August $25^{\text {th }}, 1770$, Charles Burney visited the home of retired opera star Carlo Broschi, known throughout the western world as Farinelli. Arguably the most famous castrato in the history of opera, Farinelli had retired from the stage some decades before, leaving his position in the Spanish court for the comfort of a country villa outside the city of Bologna. ${ }^{1}$ Burney_-doctor of Music, organist, composer, and music historian-was on a tour though Italy collecting manuscripts and anecdotes for his magnum opus, a history of music from the days of the Hebrews and Ancient Greeks through to the present, the latter of which he considered the pinnacle of musical achievement. Like other men and women on the Grand Tour, Burney collected as many experiences as he did sources for his book, compiling them into a musical travelogue entitled The Present State of Music in France and Italy, published to public acclaim in $1771 .^{2}$

After much discussion of the make and models of Farinelli's various harpsichords and piano fortes, the two sat down with another guest, composer-scholar Padre Giovanni Battista Martini, for dinner and conversation. Reflecting upon his many years in the most illustrious courts of Europe, Farinelli related a curious story, which Burney recorded in his travelogue:

\footnotetext{
${ }^{1}$ Charles Burney, The present state of music in France and Italy: Or, the journal of a tour through those countries, undertaken to collect materials for a general history of music, 2nd ed. (London: 1773), 210.

${ }^{2}$ Kerry S. Grant. "Burney, Charles." Grove Music Online, Oxford Music Online (Oxford University Press).
} 
His Imperial Majesty [Emperor Charles VI] condescended to tell him one day, with great mildness and affability, that in his singing he neither moved nor stood still like any other mortal; all was supernatural. "Those gigantic strides, said he; those never-ending notes and passages, ces notes qui ne finissent jamais, only surprise, and it is now time for you to please; you are too lavish of the gifts with which nature has endowed you; if you wish to reach the heart, you must take a more plain and simple road." These few words brought about an entire change in his manner of singing; from this time he mixed the pathetic with the spirited, the simple with the sublime, and, by these means, delighted and astonished every hearer. ${ }^{3}$

Burney, or rather Charles VI, makes a curious statement here: the gifts with which nature has endowed you. Needless to say, the young Carlo must have shown a great natural talent for singing, but here, as in all other references to the great opera virtuoso, Burney neglects to mention a significant detail: Farinelli had been castrated in his youth to retain his high vocal range. In other words, his powerful soprano voice was not, in fact, 'natural.' ${ }^{4}$ His long limbs, a side effect of his lack of testosterone and androgen, are likewise hinted at here; though his actual size and proportions are not mentioned, his movement is described as supernatural. Certainly, Burney felt it would be indelicateand likely a slight upon his host - to mention the unpleasant operation that made Farinelli an eighteenth-century superstar.

Human nature and the question of the 'natural' were central concerns for eighteenth-century intellectuals and physicians alike. These men and others throughout Europe saw themselves as a new breed of scholar, expanding and advancing human

\footnotetext{
${ }^{3}$ Burney, 215-16.

${ }^{4}$ Throughout, words such as 'nature,' 'race,' and 'monster' often appear in single quotations in order to highlight their importance. These terms had multiple, sometimes conflicting meanings depending on who was using them and for what purpose. While some definitions employed in the eighteenth century are still valid today (e.g., one definition of 'nature' states the term encompasses the non-manmade physical world in which we live), even these might be used in an unfamiliar way as we no longer operate from the same cultural context as our Enlightenment-era forebears. For this reason, they are 'pulled-out' with single quotations to remind the reader that, like the smoke, pulleys, and levers of French opera's deus ex machina, there is more here than what we see at first glance.
} 
society with the light of knowledge and reason - a paradigmatic shift we now refer to as the Age of Enlightenment. ${ }^{5}$ Physicians especially tried to quantify the concepts of 'nature' and 'natural' with new fields like physiology and the nascent sciences de l'homme, or sciences of man, which included proto-anthropology, ethnography, psychology, and the like. ${ }^{6}$ Such conversations occurred throughout Europe's various Enlightenments, but the most influential seat of knowledge at this time was France, specifically Paris. For intellectuals, known in French as philosophes, the problem of human passions was tied to metaphysical and ontological questions regarding emotions and the seat of the soul. ${ }^{7}$ The greatest minds of the eighteenth century sought to understand mankind by exploring the role of emotions, sensations, and sensibility in human nature, earning the period the title Age of Sensibility among modern scholars.

The castrati, while only a tiny percentage of the European population, embody many of the significant medical and philosophical questions of the Enlightenment that aimed to understand humanity: human emotion, physiology, sexuality, and culture. As a part of the ongoing debate over what was 'natural,' the castrati hold an interesting place.

\footnotetext{
${ }^{5}$ There is much more that could be added to the definition of the Enlightenment, as well: chronological boundaries, timelines, areas of study, schools of thought, main ideas espoused, prominent figures, published works, cultural context, and backlash against the enterprise. For now, we will simply say that Age of Enlightenment happened in the eighteenth century and consisted of a large, sprawling group of people, mostly men, grappling with age-old questions in ways particular to the period in which they lived. ${ }^{6}$ Proto-anthropology is an imperfect term. It is used here to denote the study and observation of other cultures or societies in a broader, less academically rigorous manner than the modern field of anthropology. ${ }^{7}$ Philosopher and philosophe are not one-to-one translations. Philosophes are best thought of as public intellectuals living throughout Europe (and to a lesser extent the rest of the word), debating everything from the art of writing comedy to Newtonian physics, often in the same conversation or treatise. While most of them engaged in philosophy, their work in a broad range of subjects was held together by the tenets of their movement: free thought based in reason instead of superstition, challenging the cultural and intellectual status quo as embodied by the old (religious) centers of learning. This basic definition is based on the entry by Paul F. Johnson, in The Oxford Companion to Philosophy. Paul F. Johnson, "Philosophe," The Oxford Companion to Philosophy, ed. Ted Honderich, 2nd ed. (Oxford: Oxford University Press, 2005).
} 
At the broadest level, the very existence of the castrati asked what it was to be a human being, being a human.

Created purely for the sake of making beautiful music, the castrati were not only abnormal but unnatural in the strictest sense of the word. That said, each castrato as part of his species had a particular set of characteristics that were natural to him. Because of this ontological ambiguity, references to the castrated body appeared in many Enlightenment texts concerning human generation, sexuality, and the nature of vital fluids as a counterexample to the natural male body.

As their own 'monstrous' species, the castrati shed light on racial taxonomization and dis/ability classifications. Their role in one of the great art forms of the eighteenth century, opera, placed the castrati at the center of moral debates surrounding verisimilitude and artificiality in aesthetics, and the corruptions and pleasures of sensibility. Lastly, the castrati were intimately connected to medico-moral texts on human sexuality as embodiments of the physical and social dangers associated with sexual deviance. By closely examining the controversy that often surrounded the castrati, historians can explore the attitudes towards this 'unnatural' human body within the context of broader socio-scientific debates over racial and cultural variety, sensibility, aesthetics, and the roles of pleasure and utility in Enlightenment discourse.

\section{The Castrati in Enlightenment Texts}

Published between 1751 and 1772, the Encyclopédie can be seen as the ultimate - though certainly not uncontested — source of truth for the philosophes, 17,000 
pages of text encapsulating the best of Enlightenment thinking. ${ }^{8}$ With nearly 45,000 main articles, ${ }^{9}$ the Encyclopédie covered nearly every known subject with varying degrees of thoroughness, and what was deemed important enough to warrant its own article tells us almost as much as what was written in the entries themselves. As such, Encyclopédie articles serve as an excellent starting point for any investigation into learned opinions on anything and everything that occupied the minds of French intellectuals in the eighteenth century.

And so, here we begin. What did the Encyclopédie have to say on the subject of the castrati? Not much, to be frank. A figure no less than brilliant mathematician and Encyclopédie co-editor Jean le Rond d'Alembert penned the brief entry, presented here in its entirety:

CASTRATI, s. m. This name, which is purely Italian, is given to those who have been made eunuchs in their childhood to give them a clearer and more piercing voice. The Castrati sing the same part as women in concerts, or soprano. See Soprano, Singer. With regard to the physical cause by which the Castrati have a weak and shrill voice; it does not seem easier to find it, than to explain why they have no beard. But the fact is certain, and that is enough. ${ }^{10}$

\footnotetext{
${ }^{8}$ The last of the seventeen text volumes, containing the approximately 17,000 pages, was published in 1765 , but the eleven volumes' worth of engraved plates was not released until 1772. "Facts and Numbers," in "Editor's Introduction" (University of Chicago: ARTFL Encyclopédie Project [Autumn 2017 Edition]), Robert Morrissey and Glenn Roe (eds), http://encyclopedie.uchicago.edu/ [hereinafter The ARTFL Encyclopédie].

9 "Facts and Numbers," in "Editor's Introduction." The ARTFL Encyclopédie.

10 "CASTRATI, s. m. (Hist. mod.) ce nom qui est purement Italien, se donne à ceux qu'on a fait eunuques dans leur enfance pour leur procurer une voix plus nette \& plus aiguë. Les Castrati chantent dans les concerts la même partie que les femmes, ou dessus. Voyez Dessus, Chanteur. A l'égard de la cause physique pour laquelle les Castrati ont la voix grêle \& aiguë; il ne paroît pas plus facile de la trouver, que d'expliquer pourquoi ils n'ont point de barbe. Mais le fait est certain, \& cela suffit." Jean Le Rond d'Alembert, "Castrati," in Encyclopédie, ou dictionnaire raisonné des sciences, des arts et des métiers, etc., eds. Denis Diderot and Jean le Rond d'Alembert, (University of Chicago: ARTFL Encyclopédie Project [Autumn 2017 Edition]), vol. 2, p. 756, Robert Morrissey and Glenn Roe (eds), http://encyclopedie.uchicago.edu/. Here and throughout, Encyclopédie translations mine unless otherwise indicated.
} 
And that's all we have to say about that, d'Alembert seems to tell us, as if to put an end to an uncomfortable conversation. Based on contemporary sources, however, there is much, much more to say about the presence of the castrati in eighteenth-century France. While there were no castrati performing on public stages, their presence left tantalizing traces in French culture.

Unsurprisingly, unflattering, gangly caricatures show up in newspapers and satirical literary works, and the men themselves grace the stages and dinner tables (and occasionally bedrooms) of the well-to-do, making appearances in contemporary travelogues. We've already met Burney, whose work serves as the main travelogue source as he was learned in music, who attended many concerts featuring castrati and was well-connected enough to spend time with them away from the stage. Castrati are also featured in multiple places in the (in)famous Giacomo Casanova's memoirs, which he began writing just a few years before his death in 1798. Casanova's History of My Life was not published until the early nineteenth century, but it is certainly one of the best sources for understanding life in eighteenth-century Europe. ${ }^{11}$ These sources and others, such as the early eighteenth-century text by French jurist Charles Ancillon entitled Eunuchism Display'd make it clear that the castrati were popular topics of conversation. ${ }^{12}$

Texts such as these tell us that castrati, as a group, were well known to the operaobsessed French public. While most members of the middle class would never meet a castrato in person, Frenchmen who traveled throughout Europe would have had the

\footnotetext{
${ }^{11}$ John Julius Norwich, introduction to History of My Life by Giacomo Casanova, trans. William R. Trask (New York: Everyman's Library [Alfred A. Knopf] 2007), xxi.

${ }^{12}$ The fact that there's a contemporary English translation of Ancillon's work speaks to the interest in the castrati in eighteenth-century England, as well. We dig into these texts in chapters two through four.
} 
chance to see them perform, whether across the channel in England where they were wildly popular, or in their home states on the Italian peninsula, which was not only a haven for the opera-loving public but for any well-heeled European taking part in the Grand Tour. In other words, while not seen or heard on the public stages in France, their presence was certainly felt.

The castrati also serve as the straw man in French debates on the relative merits of nature versus artifice in music. The most famous of these debates, known as the Querelle des Bouffons, pitted the pro-French king's followers (Coin du Roi) against the pro-Italian followers of the queen (Coin du Reine) in a pamphlet war that lasted for over two years, each side viciously arguing that their music was the best. Even though the Italian troupe whose visit started the war did not have a castrato with them, the figure of the emasculated singer hung over the proceedings like a ghost; even the pro-Italian philosophes had to admit that, for all the passion their singing might engender, the castrati were still sorry creatures. Again, without setting foot on the public stages of the Parisian Opéra or Comédie-Italienne, the castrati became part of an argument, widely known in France as a querelle, that played an integral role in the Enlightenment discourse over naturalness in the arts.

Of course, we should not be surprised to find references to the castrati in texts that focus on music, even if the writers themselves spent little or no time in the company of these singers. Once we begin to look deeper, we find the castrati in curiouser places as well. Those same singers cloistered in the Chapelle $d u$ Roi, or the king's private chapel, make their way into scientific literature exploring the human physical and emotional condition. They are part of fascinating stories about the generation and flow of electricity 
through the human body, and texts decrying the horrors of masturbation. ${ }^{13}$ They also served as a case study for physiologists exploring the mechanisms of generation and the systemic effects of puberty. ${ }^{14}$ The castrati were not considered monsters in the strictest sense as they were victims of mutilation: to be a 'monster' in the early modern scientificmedical sense, a person or animal must be born that way. ${ }^{15}$ As the castrati were presumably born with typical genitalia, their monstrousness was made by man, not nature. That said, the castrated body is often described as monstrous and certainly seen as a de-formation, a derivation from the norm, and for this reason they were often associated with others who exhibited bodily deformity, part of the parade of pitiful-yet-fascinating examples of the human form. ${ }^{16}$

On the surface, music, monstrosity, and masturbation do not appear to have much in common, aside from the fact that they were among the many topics piquing the interest of the philosophes. And yet, the castrati are there - not as leading heroic performers perhaps, but as character actors who can perfectly play the role in which they're needed. As personifications of the unnatural, the castrati here are mostly symbolic: they are embodiments of effeminate luxury, the power of music, the degradations of vice, the wonders of the human body, deviant sexuality, and the excessiveness of artifice, depending on the author's argument. This ubiquity, the seemingly polysemous nature of

\footnotetext{
${ }^{13}$ Michael Lynn, Popular Science and Public Opinion in Eighteenth-Century France (Manchester: Manchester University Press, 2006), 1. The most popular anti-masturbation text is arguably French physician Samuel Auguste David Tissot's l'Onanisme. Both texts are explored in later chapters.

${ }_{14}$ Arnulphe d'Aumont, "Eunuque," in The ARTFL Encyclopédie, vol. 6, pp. 159-61.

${ }^{15}$ See Chapter Two, "Of Monsters and Men:(Hu)men on the Margins" for discussion on disability and monstrosity in the eighteenth century.

${ }^{16}$ For more on wonders and the changing views on the marvelous in the Enlightenment, see Lorraine Daston and Katharine Park, Wonders and the Order of Nature (New York: Zone Books, 2001), especially chapter nine, "The Enlightenment and the Anti-Marvelous."
} 
the castrati, stretched over both art and science, underscoring the closeness of these two subjects in the Enlightenment.

2. The Castrati and Their (Figurative) Kin in the Secondary Literature

For most of the twentieth century, scholarly works on the castrati focused on their influence over the evolution of opera in eighteenth-century Europe, relegating them to the annals of music history. The most commonly-cited source on the history of the castrati is Angus Heriot's work entitled The Castrati in Opera. Originally published in 1956, the work has faced criticism as modern authors have applied the rigors of late twentieth- and early twenty-first century scholarship to the work. The veracity of many of its accounts have been called into question. ${ }^{17}$ There is no reason to doubt the author meant to approach the subject historically, but the work is better examined as an object of historiographical interest than as a well-written history per se. At the very least, Heriot's work must be viewed with an extra-critical eye and an acknowledgment of the constraints of mid-century scholarship on such a delicate subject.

Until recently, popular and scholarly works on eunuchism more broadly have generally focused on either the practice of castration in the ancient world or in the middle and far east through the early twentieth century. Earlier texts focus on the exotic eroticism and barbarity of the practice. Titles such as The Eunuch and the Virgin: A Study

\footnotetext{
${ }^{17}$ An expert in the field (discussed below), Martha Feldman does not even cite Heriot in her history of the castrati, relegating him to an endnote stating, in regard to castrati liaisons with women, "Heriot cites few sources and not all can be substantiated." She then recommends other secondary and primary sources on the subject. Martha Feldman, The Castrato: Reflections on Natures and Kinds (Berkeley: University of California Press, 2015), 294.
} 
of Curious Customs, published in 1962; The Keeper of the Bed: The Story of the Eunuch, published in 1973; or Hijras, the Labelled Deviants, published in 1989, offer a good overview of attitudes towards eunuchs. These works are perhaps best viewed as Orientalism at its finest, which is to say, its worst. A medical article in an issue of the British Medical Journal from the same period is rife with biases against far-eastern eunuchs, echoing age-old sentiments about the temperament of eunuchs as a group (and displaying a strong Eurocentric bias in the process as well):

The patient, aged 70, was an irascible northern Chinese from "near Tientsin" who appeared to be of great age yet, paradoxically, conveyed also an impression of youthfulness. . The history was difficult to attain, and questions were answered with reluctance in a querulous voice no higher-pitched than that commonly encountered in Chinese. Repeatedly he upbraided his friend for having brought him to see the "prying, foreign devil," from whom not even his ancestors were safe. $^{18}$

The author goes on to say that "he was even more difficult being examined," and noting that after he had examined the patient's hands and ears he examined the pubic area, at which point "the patient refused to be examined further, refused venesection, and refused, angrily, a request to photograph him." ${ }^{19}$ It seems the author treated his patient with indignity, as a curiosity, and with less compassion than he should have shown to an impoverished, elderly man suffering from severe physical pain. These quotes clearly convey the insensitive curiosity and condescending pity that writers and scholars usually displayed towards their subjects.

With the rise of multidisciplinary LGBTQAI+ studies in the 1990s, a wider range of scholars have examined the history of eunuchism with an eye to the spectrum of

\footnotetext{
${ }^{18}$ A. J. S. McFadzean, “A Eunuch Takes the Gout,” The British Medical Journal 1, no. 5441 (April 1965), 1039.

${ }^{19}$ McFadzean, 1039.
} 
human sexuality. Examining the lives of these men through the lens of modern sexuality studies, earlier works often applied modern standards and terms, while more recent works have attempted to understand these men within their cultural context. More recently, the history and study of masculinity has given us a new way in which to view their social and sexual relationships, as well as their family structure, which often included the adoption of biological nieces and nephews, as well as other castrati. ${ }^{20}$ Other scholars have written about their relationships with women and the ways in which these romantic and sexual couplings expand our views on sexuality more broadly. ${ }^{21}$ These latter scholarly works especially aim to strip away—or at the very least acknowledge — the titillation that often accompanies the in-depth look at the lives of those who deviated from social and sexual norms.

The most significant recent work examining the lives and impact of the castrati was published in 2015 by Martha Feldman, the Mabel Greene Meyers Professor of Music, Romance Languages and Literatures at the University of Chicago. Her monograph The Castrato: Reflections on Natures and Kinds, is a thorough and fascinating addition to the scholarly field. Feldman's main thesis states the castrati were a social locus for a multitude of issues in Italian society during the seventeenth through nineteenth centuries:

This book suggests that while the resolute infertility of testicular castration made filiation of wealth problematic, it was strangely but necessarily coupled with many uniquely efficacious forms of cultural exchange in which castrati

\footnotetext{
${ }^{20}$ Feldman, The Castrato, 72-73.

${ }^{21}$ For the castrati in particular, see especially Helen Berry's work on Tenducci, including "Queering the History of Marriage: The Social Recognition of a Castrato Husband in Eighteenth-Century Britain," and her later book The Castrato and His Wife. Julia Prest's "In Chapel, on Stage, and in the Bedroom: French Responses to the Italian Castrato," is another excellent secondary work on castrato sexuality.
} 
participated, and in such varied domains as music making, composing, reputation building, networking, power brokering, courting, and estate and legacy building. ${ }^{22}$

While Feldman's book and this thesis both look at the relationship between 'nature,' 'the natural,' and the castrati, there are several crucial points that set these works apart even if the general statements appear quite similar on the surface. First, Feldman is not a historian of science, nor technically a historian at all. Her painstaking documentation is both admirable and extremely useful for other scholars studying the castrati, but her work involves far more literary and anthropological theory than historical analysis, and therefore her approach differs from the practice of history.

Secondly, Feldman rarely touches upon French or English sources about the castrati, preferring instead to situate them within their home country of Italy, which is the geographical focus of much of her work. ${ }^{23}$ Likewise, Elizabeth Krimmer's article “"Eviva il Coltello?' The Castrato Singer in Eighteenth-Century German Literature," also notes the potency of castrato-as-metaphor, focusing on his relationship with aristocratic culture and its (un)naturalness, especially in regard to the effeminacy of the aristocracy, ${ }^{24}$ but offers no context, and no definition of 'natural,' and focuses only on the writings of German writers concerned with the depredations of German aristocracy.

\footnotetext{
${ }^{22}$ Feldman, The Castrato, xii. The majority of research and the basic thesis for An Idolatry of Sound-that the castrati should be viewed as an embodiment of broader cultural anxieties - were already in place when The Castrato was published. It has been both gratifying and frustrating to reach a similar, broad conclusion independently, as Feldman is a well-respected expert on the subject. However, beyond the statement "the castrati were more than they seem, they represented things to people," our theses diverge in multiple ways. ${ }^{23}$ Her other main work on opera, Opera and Sovereignty, also focuses on Italy. Martha Feldman, Opera and Sovereignty: Transforming Myths in Eighteenth-century Italy (Chicago: University of Chicago Press, 2007).

${ }^{24}$ Elizabeth Krimmer, “'Eviva il Coltello'? The Castrato Singer in Eighteenth-Century German Literature and Culture," PMLA 120, no. 5 (October 2005): 1544.
} 
Lastly, and most importantly, neither Krimmer nor Feldman's work engages with Enlightenment science, or with the broader scientific and philosophical debates of the eighteenth century that explored what it meant to be human, or how 'the natural' was defined and debated more broadly during this time. Feldman notes the use of 'cold' as a Galenic medical term, and briefly touches upon the idea that the 'coldness' of the castrati was, by the mid-eighteenth century, at odds with the heroic roles they often played. The castrato as virile hero was not truth to nature. ${ }^{25}$ Her book also contains a mention or two of Rousseau, but no analysis of the role the querelles in particular or French opera in general played in the Enlightenment debates on naturalness, artifice, and mimicry in the arts, or on the broader debate about human nature. ${ }^{26}$ If we consider The Castrato: Reflections on Natures and Kinds to be the most cutting-edge work on the castrati, we can see that there is still room to expand her general thesis - that the castrati represented different things to different people - beyond her field of specialty into the history and philosophy of science. As such, approaching the topic of music, feeling, and the castrati from a socio-scientific perspective, as this thesis does, will still yield new insight into the science of man and the way in which it thoroughly permeated European society in the eighteenth century.

The castrati were no strangers to controversy; the higher their star rose, the more controversy they courted. Both individually and as a group, the singers' fame made them

\footnotetext{
${ }^{25}$ Feldman, The Castrato, 207.

${ }^{26}$ Feldman discusses eighteenth-century denunciations on pages 177-81 of The Castrato; she discusses the French response which held Nature as sacrosanct, on pages 179-80. Here, she cites Rousseau's Dictionnaire de musique entry on castrati, referencing it again on page 188.
} 
excellent targets for moralists, who projected many of the Enlightenment's most urgent cultural tensions upon them. Based on the multitude of sources available, it is clear that debates and controversies surrounding the castrati never existed in isolation, relegated only to discussions on opera. Instead, the bodies, abilities, and habits of the castrati became part of the philosophes' competing conceptualizations of 'human nature': the taxonomization of humanity based race and dis/ability, the physical basis of sensation and sensibility, the role of nature versus artifice in creative endeavors, and what could be considered 'natural' in terms of sexual conduct and expression. The castrati, then, functioned as a kind of field of experiment, their very existence used to test these hypotheses and 'prove' one mental schema over another.

In order to understand the various roles the castrati embodied, we must first understand how 'humanity' was defined in the eighteenth century. Chapter one reviews contemporary ideas on the role of external forces such as geography and climate in the creation of human variety. Climate was also seen as a determinative factor in the creation of culture because it affected bodily sensations, and therefore the sensibilities, of a given race. At the heart of this issue was the debate over sensibility and its variation across climates and cultures - the castrati, who were almost exclusively Italian, served as both an example of the bizarre (to the French) customs of the Italians, and 'proof' that what seemed natural to one society was abhorrent to another. As the field of physiology evolved, the medicalization of emotion added scientific credibility to the taxonimization of human variety through eighteenth-century understandings of nerve structure and the so-called 'economy of fluids.' As these medical theories progressed, taxonomy became hierarchy, laying the groundwork for centuries of racial oppression. 
A further taxonomization involved the separation of humans based on dis/ability. In chapter two we examine the categorization of mutation and ability in the Enlightenment, and the role of dis/ability in the complex debates over what is 'natural' when it comes to the human body. Is a body born different less 'natural' than others? Where is the line between 'normal' and 'monstrous,' and who has the power to make that distinction? The castrati, unnatural and man-made, offer a fascinating case study of a 'monstrous' species. As with the variety of other human races, the castrati had their own distinct nature based on their specific biological difference and particular customs.

Chapter three situates the castrati in their natural habitat, the world of opera. More than simply a place to see and be seen, the French opera house was a microcosm of society. Here, we delve into the eighteenth century's philosophical debates on opera, known in France as querelles. These querelles were fertile ground for exploring ideas around the (mis)use of mimesis and verisimilitude in the arts, and the potential danger of using artifice to arouse the passions. Based on contemporary medical theories, the castrati's 'unnatural' voice had the power to help or harm through extreme excitation of the passions. In this way, the castrati embodied of one of the philosophes' most vexed questions: should 'nature' take precedence over artifice?

Lastly, the trope of castrato-as-lover reveals the deep cultural anxieties surrounding human sexuality. In chapter four, we find the castrati embroiled in questions about 'natural' and 'unnatural' sexual pleasures. Due to their inability to procreate, the castrati were often invoked in debates on the dangers of masturbation-like selfgratification, sexual congress with a castrato may have led to fewer physical consequences but placed the soul in danger. This connection between castrato sex and 
masturbation merely underscored the dangers of 'unnatural' sex for the individual and society at large.

From the relationship between racial difference and climate, to the bedrooms of the aristocracy, references to Europe's first superstars highlight their complex, polyvalent role in many of the Enlightenment's most fundamental debates on what it meant to be human. 


\section{Chapter One}

Human, Body and Soul: The Science of Man in the Eighteenth Century

Before we can examine the ways in which castrati challenged eighteenth-century Europe's concept of what it meant to be a man, to be human, it is necessary to review what 'humanity' meant to those who studied it in detail. Contemporary ideas on the origins of race and culture in particular informed French attitudes towards Africans, Indigenous Americans, Asians, and even southern Europeans. They certainly played a role in French values surrounding Italian opera in general and the castrati in particular.

In England and France especially, the connections between race, climate, and culture appear in popular cultural references. Overall the Italians fared poorly in the opinion of their northern neighbors: sodomy was often referred to as "the Italian vice" and an effeminate Englishman might be derided as a macaroni-both illustrative of ethnocentric prejudices common in Europe at the time. More pointedly for this study, the English title for Ancillon's aforementioned treatise on eunuchism is Italian Love. Indeed, for northern Europeans of this era it would be impossible to understand a culture, or how it developed, without understanding the geography and climate in which it originated. As an outside influence that affected all peoples, climate in particular was seen as a determinative factor which could explain how and why certain groups of people acted, thought, and even developed language in a certain way.

Climate, geography, and native vegetation were considered outside forces which shaped the internal sensibility of a given group of people, resulting in the different cultural norms throughout the world. On an individual level as well, sensibility — the 
body and mind's reaction to stimuli-varied from person to person based on their particular constitution. A new theory in the eighteenth century, sensibility soon became the lens through which the human body, behaviors, and emotions were understood. Indeed, the philosophe-encyclopedists, along with many of their contemporaries, used their own sensibility and sentiment as a way to understand the universe. ${ }^{27}$ Sensibility was an integral part of the so-called 'animal economy,' or sum of sensations arising from the entirety of an organism's sensible parts. ${ }^{28}$ In this way, the most ineffable parts of the human experience, the emotions - often referred to as 'the passions' in the eighteenth century-were medicalized as a part of the human machine, with its subtle fluids and imperceptible vibrations.

Likewise, the new and exciting field of electrical medicine, especially Mesmerism, gained popularity among the European lay public in the mid-eighteenth century. Mesmerism promised to harness the natural power of electricity, popularized by traveling or impromptu public shows, to heal and reset the subtle, sensible fluids of the animal economy as one might reboot a computer today. While Mesmerism ultimately failed, the theories behind it remained a part of mainstream medical thought. ${ }^{29}$ Taken together, these discussions attempted to answer some of the oldest questions about the function of the human physical and emotional body, and the way in which external stimuli shape human beings on an individual as well as cultural level using the nascent sciences de l'homme.

\footnotetext{
${ }^{27}$ Jessica Riskin, Science in the Age of Sensibility: The Sentimental Empiricists of the French Enlightenment (Chicago: University of Chicago Press, 2002), 15.

${ }^{28}$ Philippe Huneman, "Montpellier Vitalism and the Emergence of Aliensim in France (1750-1800): The Case of the Passions," Science in Context 21, no. 4 (2008): 617.

${ }^{29}$ Riskin, 196; 198.
} 
In other words: forces like climate affect the bodily sensations, which affect sensibility and emotion, which shape culture, which creates societies. These societies, in turn, create art, stories, and customs that reflect their social values. Within each culture, as within the human race as a whole, there is a full spectrum of individuals who experience, feel, and participate their society based on their personal constitution. Many on the edges of society, whether by dis/ability or socio-economic status, defied the climate-sensibility-society framework by their very existence. Others, like the castrati, illustrated to outsiders how far such a framework could stretch to accommodate the bizarre customs of other races. For the philosophes especially, the castrati served as an example of the often-extreme sensibilities of the Italians, with the singers themselves seen as quintessentially Italian in their actions and attitudes. Beyond their place as members of the Italian race, the castrati were a race in and of themselves, with their own set of physical characteristics, peculiar habits, and temperament due to their unusual animal economies. Therefore, in order to understand how the castrati became their own 'race,' we must first examine the broader conversations on race and sensation in the eighteenth century.

1. Taxonomizing Man: Climate, Culture and the Creation of Race

In one of the emblematic works of the Enlightenment, The Spirit of the Laws, Montesquieu states:

You will find in the northern climates peoples who have few vices, enough virtues, and much sincerity and frankness. As you move towards the countries of the south, you will believe you have moved away from morality itself: the liveliest passions will 
increase crime; each will seek to take from others all the advantages that can favor these same passions. In temperate countries, you will see peoples whose manners, and even their vices and virtues are inconstant; the climate is not sufficiently settled to fix them. ${ }^{30}$

With this, the Président à Mortier and philosopher is at once echoing the classical tradition of climate-based difference while also drawing upon the growing scientific debate regarding the relationship between race, culture, and climate. Published in 1748, The Spirit of the Laws anticipates the broader conversation that would preoccupy the encyclopedists and men of letters for the next several decades — indeed for the next two hundred years. However, it is during the second half of the eighteenth century that European doctors, philosophers, and explorers would change the way in which concepts of variation among human beings_-often colloquially referred to as 'race'-were applied to various human populations.

By connecting old xenophobic prejudices to contemporary scientific knowledge of the human body, these European men participated in a scientifico-cultural dialogue that would ultimately lead to centuries of science-based oppression. Supported by field reports from the explorer naturalists that accompanied the colonists and sea-faring explorers as well as the popularity of taxonomy, the Enlightenment philosophes created a new hierarchy of humans. Resembling the Classical schema espoused by Aristotle, Pliny, and later St. Isidore of Seville, this new family tree was couched in the language of the sciences de l'homme.

\footnotetext{
${ }^{30}$ Charles le Secondat, Baron de Montesquieu, The Spirit of the Laws, trans. Anne M. Cohler, Basia Carolyn Miller, and Harold Samuel Stone (Cambridge: Cambridge University Press, 1989), 234.
} 
In addition to founding the science of race, which came into its own in the next century, Enlightenment writers on race, culture, and climate also addressed the question of human origins. How, if we look so different, can we all come from the same stock? This question, which became the debate over monogenesis versus polygenesis-from one stock or many —informed, and was informed by, the taxonomic impulses of the eighteenth century. But unlike the classification of plants or animals, the classification of man had ramifications which even the most enlightened thinker of the century could not have imagined, either in its future intensity or global longevity.

The usual suspects from the Enlightenment weighed in on the question of race and the origin(s) of humanity: Buffon, Maupertuis, Voltaire, Montesquieu and many other men of letters, including the encyclopedists, spilt ink on the subject in France. ${ }^{31}$ Some authors either came from the colonies or moved to them, spending their time surrounded by men and women they perceived as distinctly different from themselves. Modern scholars urge us to remember that, while most men in both of these categories likely saw different races—especially Africans—as less refined human beings than Europeans, this did not necessarily translate into a tacit approval of slavery. Historian Nicholas Husdon reminds us that many philosophes, including men like the Abbé Raynal, absolutely abhorred the institution of slavery while still upholding the superiority of the white race. ${ }^{32}$ While there are a plethora of philosophical treatises and travelogues that touch on the intertwined concepts of race, culture, and climate, the most influential

\footnotetext{
${ }^{31}$ Neither Maupertuis nor Buffon contributed directly to the Encyclopédie, though both were cited numerous times, in many different articles. While the theory of monogenism was the most popular among philosophes, some, like Voltaire, still advocated for polygenism. See below.

${ }^{32}$ Nicholas Hudson, "From 'Nation' to 'Race': The Origin of Racial Classification in Eighteenth-Century Thought," Eighteenth-Century Studies 29, no. 3 (Spring 1996), 251.
} 
remain the ones written by the philosophes, who inspired others to take up the subject for themselves. As Dorinda Outram has noted, the paradox of slavery and equality, so bound up within this discussion of race and the fuzzy edges of humanity, is one of the great paradoxes of the Enlightenment. ${ }^{33}$

One of these men, Pierre-Louis Moreau de Maupertuis, was by modern definitions a mathematician, physicist, and biologist. First a Cartesian and later a Newtonian, Maupertuis is perhaps best known for traveling through Lapland to measure the curve of the earth. In addition, his mathematical-philosophical treatise on the principles of movement and rest served as the inspiration for many generations of mathematicians and is quoted multiple times in the Encyclopédie by D'Alembert. ${ }^{34}$ As a proto-biologist, too, Maupertuis proposed innovative theories on the nature of living things, known in the eighteenth century as the botanical and zoological branches of natural history. He was especially keen on the subject of mutation, often referred to as 'monstrosity' in contemporary literature. ${ }^{35}$ His work on heredity and mutation-monstrosity, entitled Venus Physique, known as The Earthly Venus in English, is a fascinating work of speculative biological anthropology (to use a modern anachronism). The second half of this work, "Varieties in the Species of Man," drew from contemporary travelers' accounts. ${ }^{36}$ They describe the giants of the Cape, the tiny Lapps of the icy north, the men in Borneo with

\footnotetext{
${ }^{33}$ Dorinda Outram, The Enlightenment (Cambridge: Cambridge University Press, 2005), 70.

${ }^{34}$ Rüdiger Thiele, "Maupertuis, Pierre-Louis Moreau de," Encyclopedia of the Enlightenment, ed. Alan Charles Kors (Oxford: Oxford University Press, 2002).

${ }^{35}$ We discuss monstrosity, deformity, and their definitions in chapter two.

${ }^{36}$ See The Earthly Venus, chapter one. Pierre-Louis Moreau de Maupertuis, The Earthly Venus, trans. George Boas (New York: Johnson Reprint Corporation, 1966).
} 
tails, and the owl-men at the isthmus of America. ${ }^{37}$ On the latter, Maupertuis informs us

that:

On the isthmus that separates the northern ocean from the Pacific, we are told, men, whiter than any known to us, are found. Their hair might be mistaken for the whitest of wools. Their blue eyes, too feeble to stand daylight, open only in the darkness of night. They are in the human species what bats and owls are in the realm of birds. ${ }^{38}$

It is easy to dismiss this story, taken from an early eighteenth-century journal by Lionel Wafer, as pure fiction. However, Maupertuis' desire to include it suggests he is following in the great taxonomist-biologist Carl Linnaeus' footsteps by taxonomizing the species of man, perhaps even in the plural, and placing human beings clearly in the realm of the natural as subjects of both natural history and natural philosophy.

While Maupertuis attempts to offer a broad taxonomic description of different varieties of man, he also connected skin color to geographic distribution, stating, "the most remarkable phenomenon and the most constant law concerning color in the earth's inhabitants is that wide band round the globe from the Orient to the Occident, called the Torrid Zone, is inhabited only by black or darkly colored people . . Leaving the Equator the color of the people becomes lighter in shade." ${ }^{39}$ The description of races and their relationship to climate was not central to Maupertuis' aims, but the 'natural law' of the torrid zone and the gradation of colors - darkest at the equator and lightest at the pole-

\footnotetext{
${ }^{37}$ Maupertuis seems to take this as a fact, but is not sure whether they are human, or if the current classificatory system can find a place for them among rationalis: "Do the inhabitants of the Borneo forests, spoken of by travelers, and who are so similar to men, think less well for having tails like monkeys? Should that classification which we have not made dependent on the color white or black be made according to the number of vertebrae?" 64-65. The problem of classifying orangutans is one of the more fascinating ontological problems of Enlightenment taxonomy and has been the subject of several books and articles.

${ }^{38}$ Maupertuis, 65.

${ }^{39}$ Maupertuis, 66.
} 
fits within the broader cultural context of taxonimization and the classification of nature. By presenting this notion as a law of nature in the vein of Newton's laws, Maupertuis participated in one of the main enterprises of the Enlightenment: the classification and systemization of the known universe, including all the races of humanity.

Despite his apparent wonder at the varieties of man, Maupertuis was firmly in the camp of the monogenists. He states this explicitly in the introduction to chapter two, "An Explanation of the Phenomenon of Color Difference in Ovim and Animalculism": "Have all of these different peoples we have just enumerated, with such a diversity of men, come from one mother? We cannot doubt it." ${ }^{, 40}$ At this point, Maupertuis begins his discussion on heredity, though he does not use that term. As he noted in the first section, most natural philosophers believed that both parents contribute material to the offspring because a black parent and a white parent create a mixed child. This is mirrored in the race as a whole, as humans are not simply black and white, but encompass a thousand other shades. Some variations disappear and reappear in later generations, the result of chance in humans and of art in domesticated species like dogs and pigeons. ${ }^{41}$

While he certainly sees all varieties as descending from a single type, Maupertuis' theory does not resemble modern evolution theory in any other way. In the last two chapters of the Earthly Venus, he gives evidence that white man is the original human, and that all others are merely a degraded form of the first, perfect human specimens. Tying back in to his discussion of the blancs nègres, which we would now classify as African albinos, Maupertuis notes that, just as features may skip a few generation and

\footnotetext{
${ }^{40}$ Maupertuis, 69.

${ }^{41}$ Maupertuis, 70-71. Pigeons are an extremely popular example of the creation of varieties by art.
} 
reappear later, the birth of white babies to black mothers and fathers is an example of the same phenomenon. ${ }^{42}$ As for their prevalence in the torrid zone, these first 'degraded' dark-skinned people were sent off to live away from the purer men, just as dwarves and giants were exiled to the harshest climates on the edge of the habitable world. ${ }^{43}$

Montesquieu's Spirit of the Laws was one of the most-cited texts about race and climate among both his contemporaries and the next generation of lumières. Enlightenment physiology was still in its infancy when Montesquieu was writing, but nevertheless he posits a mechanical explanation for the temperaments of different peoples in the introductory section of Part Three:

Cold air contracts the extremities of the body's surface fibers; this increases their spring and favors the return of blood from the extremities of the heart. It shortens these same fibers; therefore, it increases their strength in this way too. Hot air, by contrast, relaxes these extremities of the fibers and lengthens them; therefore, it decreases their strength and their spring. ${ }^{44}$

Montesquieu states that because of this physiological difference, the peoples of the northern climates have "more confidence in oneself, that is, more courage; better knowledge of one's superiority, that is, less desire for vengeance." 45 He continues in this vein, citing what he considers to be the finest traits of humanity, and tying them to the spring of nerves. To drive home the point that virtue is rooted in climate, he then notes that if you "put a man in a hot, enclosed spot, and he will suffer, for the reasons just

\footnotetext{
${ }^{42}$ Andrew Curran's article "Rethinking Race History: The Role of the Albino in the French Enlightenment Life Sciences" offers the blancs nègres as a fascinating case study into the problem of human origins, and degeneration in the Enlightenment. Andrew Curran, "Rethinking Race History: The Role of the Albino in the French Enlightenment Life Sciences," History and Theory 48, no. 3 (October 2009): 151-79.

Maupertuis, 81 .

${ }^{43}$ Maupertuis, 84.

${ }^{44}$ Montesquieu, 231.

${ }^{45}$ Montesquieu, 232.
} 
stated, a great slackening of heart ... The peoples in hot countries are timid like old men. ${ }^{46}$

After speaking about these concepts in the abstract, Montesquieu then goes on to give examples, citing ancient Germanic law codes as well as the work of missionaries and explorers to illustrate the distribution of courage among peoples of various climates. ${ }^{47}$ The lack of courage due to enervation is, for Montesquieu, the reason that peoples from hotter climates tended to be easy victims of the slave trade. However, he does not suggest that this cowardice is an inborn trait based on skin tone, but rather related to climate-based enervation: he writes of the Americans as a homogenous ethnic group —although to put it in these terms is certainly an anachronism—but he notes that "the despotic empires of Mexico and Peru were near the equator, and almost all of the small free peoples were and still are toward the poles. ${ }^{48}$ Indeed, he does not mention skin tone at all, not even to suggest a correlation between the amount of sun in a given region and skin color.

Based on this section of The Spirit of the Laws, it seems clear that Montesquieu did not view race as something innate in the physical body, as the various virtues and vices of men appear to him to be wholly climate-based. He notes that a northerner sent to a warm climate would lose his predilection for courage and virtue but does not explicitly state the opposite would be true: that a timid man from a warm country would suddenly find his courage. However, based on the physiological theories that take up the first few pages on his book about climate and its relationship to governance, the reader can assume

\footnotetext{
${ }^{46}$ Montesquieu, 232.

${ }^{47}$ Montesquieu, 296; 278.

${ }^{48}$ Montesquieu, 278.
} 
that this is possible, at least in the abstract sense. This taxonomy of government also assumes a monogenic origin of humanity, as he notes a different strength of nerves, not a different type. If there are physical disparities between men, it is due to outside influence, not inborn difference.

While Maupertuis' descriptions hinge on skin color and Montesquieu's focuses on the strength of the nerve fibers to describe difference, Jean-Louis Leclerc, better known as the Comte de Buffon, chose to focus on height and facial features instead. Buffon's Histoire Naturelle, which took five decades to complete and spanned thirty-six volumes, touched on nearly every natural phenomenon known to man. While the work as a whole redefined the scope of knowledge for the Western world, Buffon reasserted the ancient ontological connection between climate, custom, and external difference among humans. ${ }^{49}$ Like all natural philosophers living in a post-Columbian world, Buffon attempts to confirm the theories of the ancients with examples from the New World. A case in point are the so-called "Esqiumaux Indians of the new continent," who resemble the "degenerate" Laplanders the most, as well as "the Danes, the Swedes, the Muscovites" and other peoples of the extreme northern lands. ${ }^{50}$

Unlike the slavers and plantation owners who saw the majority of non-Europeans in terms of their geographical location — for example Africans as one savage group and American Indians as another-Buffon is intent on highlighting the physical and cultural differences found among the inhabitants of these vast continents. An excellent example of this racial-cultural gradation can be found in his description of the Ethiopians, where

\footnotetext{
${ }^{49}$ Georges Louis Leclerc, comte de Buffon. Buffon's Natural history, abridged, elegantly engraved . . . (London, 1791), 59. Eighteenth Century Collections Online.

${ }^{50}$ Buffon, 59.
} 
he states that natural-philosophers have long been in error: "By confounding them with their neighbors the Nubians, we have been long in error, with respect to the color and features of the Ethiopians... The truth ... is that they differ from the Nubians both in color and in features. ${ }^{.51} \mathrm{He}$ seems to find their features regular enough to be attractive, unlike their southern neighbors, the so-called Hottentots, whom he deems a "nasty people" based on the descriptions of the Dutch. ${ }^{52}$ In addition, the Ethiopians are different from many of the African peoples in that they "are a people between the extremes of barbarism and civilization" who wear silk and cotton garments, but are not skilled in the arts and sciences. ${ }^{53}$

As Montesquieu attributes different forms of governance to the heat of the climate - by way of physiological traits - Buffon echoes this notion of the supremacy of climate. However, he also notes several vexed questions, for example, why Tartars are darker than Europeans at the same latitude, and also darker than the Chinese, whom Buffon notes they resemble otherwise. Here, we see common cultural prejudices come into play, and the correlation between skin tone and civilization. While the latter could be read simply as xenophobia couched in scientific musings, the comparison between the Tartars and the Chinese offers a better example of Buffon's theory:

Why are the Chinese whiter than the Tartars, whom they resemble in all their features? It is because they live in towns, they are civilized, because they are provided with every expedient for defending themselves from the injuries of weather, to which the Tartars are perpetually exposed. ${ }^{54}$

\footnotetext{
${ }^{51}$ Buffon, 68 .

${ }^{52}$ Buffon, 70-71.

${ }_{53}^{53}$ Buffon, 68.

${ }^{54}$ Buffon, 74.
} 
In other words, weather and climate play a role post-facto-it is the lack of civilization that precedes skin color, and then becomes a marker for its absence. ${ }^{55}$

Like Maupertuis and Montesquieu, Buffon also appears to be a monogenist, who, like Maupertuis, sees darker skin as a marker of degeneration. He cites climate as a main cause of this, not only because the temperature effects the human body (as in The Spirit of the Laws) but because climate affects the vegetation, and therefore a group's ability to farm or raise animals for food, which in turn affects the health and beauty of a people in a certain geographical-climatic region. ${ }^{56}$ Farther down the same page, Buffon ties his examples of food, air, and soil together to advocate for the single origin of mankind, which has nevertheless devolved into many varieties of the species. He suggests that as the first humans spread over the earth, they were all the same, but:

[A]fterwards, from the continued action of the above causes becoming more general, more sensible, and more fixed, they formed varieties in the species; that these have been, and are still perpetuated from generation to generation, in the same maker of certain deformities ... and that, in fine, as they would never have been produced but by a concurrence of external and accidental causes, as they would never have been confirmed and rendered permanent but by time, and by the continued action of these causes. ${ }^{57}$

Like Maupertuis, Buffon draws upon known examples of hereditary disease to show the possibility that, were such 'deformities' continually passed down among a group, and reinforced by the continued effects of climate, that human beings could easily become as diverse as they appeared in the modern world. That said, Buffon also explicitly states that he believed the process could be reversed — in other words, that the "degenerate races of

\footnotetext{
${ }^{55}$ Buffon, 74.

${ }^{56}$ Buffon, 75 .

${ }^{57}$ Buffon, 75 .
} 
man" could theoretically regain their former glory given enough time ${ }^{58}$ For Buffon, there are no fixed races, simply varieties which have been fashioned by external forces over the millennia of human existence. He certainly makes a value judgment when he describes non-white, non-Europeans as degenerate, but his schema does not present them as ontologically different or less than, simply at the mercy of climate.

It should be noted that neither Maupertuis nor Montesquieu use the word 'race,' preferring words like 'variety' or 'type.' Buffon was the first to employ this word as a way of differentiating between groups. However, he still made use of the term 'variety,' which was an integral part of the Linnaean taxonomic system. ${ }^{59}$ This usage of the word race was not common, however, until well into the 1770 s. Indeed, this change was a midcentury phenomenon, a point which has been noted by modern scholars and informed the way they study the changing theories on the connection between different types of people, their cultures, and their locality. Historian Nicholas Hudson traced the etymology of these words, as well as the changing intellectual practices that helped to situate terms like 'race,' 'tribe,' and 'nation,' making them into the words as we understand them today. Where the word 'nation' once meant any large group of people, it increasingly became tied to the western idea of the nation-state the eighteenth century progressed; 'tribe' became a signifier of the opposite, or those who lacked the level of civilization found in the west. ${ }^{60}$ As these words increasingly came to refer to civilization—or a lack thereof - in the last decades of the eighteenth century the word 'race' came to replace

\footnotetext{
${ }^{58}$ Buffon, 75.

${ }^{59}$ Hudson, 253. Hudson also notes (255) that Buffon's system was not very consistent, and he often switched out the word 'races; for words like 'kind' or 'species.' This further strengthens the point that the meaning of the word race was still very much in flux.

${ }^{60}$ Hudson, 248.
} 
these terms in Enlightenment discourse on humanity and human origins. ${ }^{61}$

Historian of science Snait B. Gissis traced the way in which these terms were coded into art, examining illustrations from travelogues and depictions of various groups in natural-historical texts. Gissis' work focuses on how two separate-but-related discourses — which the author calls "the discourse on society, civility, and civilization" and the "discourse on nature" — gradually became one, and the trappings of any given civilization were coded into illustrations of men and women from around the world. ${ }^{62}$ These works presented both diversity and unity, especially in the case of those who favored monogenesis. ${ }^{63}$ The staggering variety of human facial features, skin color, and customs were taxonomized and placed within a hierarchy, which set some groups on the edge of humanity (Bouffon's Hottentots) while others were situated in the middle, the pinnacle of human cultural achievement. ${ }^{64}$

Gissis argues that after the 1760 s — around the time that Hudson states the idea of 'nation' was being associated with western government - artists began to portray nonwestern peoples in violent, chaotic scenes. These effectively negated, and often completely erased, the earlier depictions of clothing or religious ritual that had previously identified their customs. ${ }^{65}$ In addition, discussions about the varieties that could be found on other continents - for example, Buffon's section on the Ethiopians — began to homogenize Africans and Indians into larger groups, which in turn were tied to sets of

\footnotetext{
${ }^{61}$ Hudson, 257.

${ }^{62}$ Snait B. Gissis, "Visualizing 'Race' in the Eighteenth Century," Historical Studies in the Natural Sciences 41, no. 1 (Winter 2011): 41-42.

${ }^{63}$ Gissis, 46.

${ }^{64}$ Gissis, 70-71.

${ }^{65}$ Gissis, 88.
} 
characteristics, whether cognitive or behavioral. Most importantly, Gissis states, like any plant or animal that was registered in the taxonomic system, "human individuals did not have to exhibit each and every external feature of a group in order to be classified as belonging to it. ${ }^{966}$ In other words, one or two features were enough to tie an individual to a set of supposed characteristics that were now coded onto the body, to make them part of the typos.

While Maupertuis used biracial men and women as an example to counter preformationism, these authors do not really attempt to discuss the mixing of races and its possible effects on European society. This was still fairly uncommon in Europe, so the Enlightenment philosophes received most of their information on this subject from the colonies. Travelogues and so-called "Descriptions" shed light on theories of mixing, which at once draw upon old prejudices in the name of modern science. The question of métissage, or race mixing, has received quite a lot of attention in recent scholarship, as it sheds light on the evolution of the term 'race,' the solidification of a hierarchy of human beings, as well as the role of gender in mixed sexual relationships.

Colonial jurist and historian Médéric-Louis-Élie Moreau de Saint-Méry, for example, incorporated algebra and statistics into his Linnaean-inspired taxonomy of the various peoples of St. Domingue. Using mathematics and statistical models, Moreau de Saint-Méry desired to predict the numbers of any given variety of mixed-race individual. Because of his place within the governmental hierarchy, such questions were more than philosophizing: they were integral in understanding the possible political consequences of

${ }^{66}$ Gissis, 90. 
métissage ${ }^{67}$ Moreau de Saint-Méry notes, much to the chagrin of the colonial taxonomers, that skin color and genealogy were not always necessarily correlates. In other words, while admitting that his system was not really useful, the jurist still insisted on using it as a map, so to speak, of skin color among the islanders. For cultural historian Doris Garraway, the fact that it was near-useless but still held up as an important scientific tool is more proof of the paranoia that gripped white islanders at the end of the century, as they were faced with a growing number of mixed-race freemen. ${ }^{68}$ Unlike the endeavors of his continental predecessors in the mid-century, Moreau de Saint-Méry's work had consequences, and therefore carried an immediacy not found in Buffon or Montesquieu.

The idea of selective breeding was also coming to the fore in France as well under the guise of conjugal hygiene, which was tied to the concept of meliorism in the last decades of the eighteenth century. If heredity was not fully understood in the modern sense of the word, it had long been understood that certain traits could be passed on, as noted in Maupertuis and Buffon. The colonial race-mixing did not differ greatly from the ideas offered up by the meliorists in Europe, except for the very horrifying fact that in the colonies like Saint Domingue, the government and the plantation owners were trying to breed an entire new race of men to serve as their insular army. The two historical actors here, Gabriel de Bory and Michel-René Hilliard d'Auberteuil, both part of the white, European governing class, were the first to suggest a selective breeding program carried out in a specific time and place (as opposed to some abstracted, utopian thought-

\footnotetext{
${ }^{67}$ Dorris Garraway, "Race, Reproduction, and Family in Moreau de Saint-Méry's 'Description...de la partie française de l'isle Saint-Domingue," Eighteenth-Century Studies 38, no. 2 (Winter 2005): 227. ${ }^{68}$ Garraway, 232.
} 
experiment). Bory and d'Auberteuil were attempting to use the enslaved population "as human instruments of empire," a mixed-race army for the express purposes of protecting the island from English or Spanish invasion, keeping the white minority in power by policing the enslaved population, and fostering loyalty towards the mixed-race militia by allowing the whites to opt-out of service. ${ }^{69}$

As the hand of nature had created Buffon's varieties through climate and diet, so too could the hand of man create a new category. Natural historians had already noted that plants from one place and climate could grow and flourish in others, sometimes to the detriment of the original plant, animal, or human inhabitants. This adaptability, or malleability, could be extended to humans. And, with the slave populations in the colonies, they had no right to say no to a selective breeding program. Nelson notes that, while d'Auberteuil wanted to create a new, fixed race of men, others, like Bory, saw the concept of selective breeding as a way to improve the overall human race. ${ }^{70}$ In a climate where Europeans felt distinctly out of place, the creation of a mixed-race group would also mean the creation of a better adapted pool of men from which to choose the militia recruits.

Charles-Augustin Vandermonde's treatise on improving the human species shows that the physician and philosophe offered a similar melioristic approach, but from a very different perspective. Vandermonde's theories can be situated explicitly within the context of his own life: born in Macao to a French father and a Portuguese-Asian mother, he moved back to France as a child and was known in his lifetime as a very attractive

\footnotetext{
${ }^{69}$ William Max Nelson, "Making Men: Enlightenment Ideas of Racial Engineering," American Historical Review 115, no. 5 (December 2010): 1369.

${ }^{70}$ Nelson, 1374.
} 
man. ${ }^{71}$ So, while Vandermonde's work can be seen as an attempt to come to terms with his own existence, he was also an accomplished physician who hypothesized that interracial marriage was the best way for the enervated upper-classes to become reinvigorated, thereby creating a stronger nation. ${ }^{72}$

Vandermonde clearly believed that geography played a role in health and beauty, noting that the most attractive people in the world were generally found in port cities, where men and women from all over the world could meet and intermingle. ${ }^{73}$ Publishing in 1756, Vandermonde appears to be ahead of his time with his theory on interracial marriage; on the other hand, his work paved the way for later writers on race-mixing, who had similar, but less noble, goals in mind. Like a métis army created for a specific purpose, can we also view the popularity of the castrati in the eighteenth century as a byproduct of melioristic thinking? Perhaps there is no direct line between the two, but the castrati were indeed an 'improved race' of singers, created by man for an explicit purpose.

As with most shifts in broad cultural concepts, it is impossible to pinpoint the exact text or a specific year when 'variety' was cast aside for 'race,' but it is clear that mid-century philosophes, physicians, explorers, and colonial bureaucrats were all grappling with similar ideas, seeking to crystalize terms to support their agenda. For some, this was demonstrating scientifically that Europeans were the pinnacle of a many-

\footnotetext{
${ }^{71}$ The authors do not state what her distinct lineage might be; her name, Cecília Esperança de Cacilhas, does not provide any information on her, other than to highlight the Portuguese law that their men must intermarry with the local women, hence her Portuguese name. Clara Pinto-Correia and João Lourenço Montiero, "Science in Support of Racial Mixture: Charles-Augustin Vandermonde's Enlightenment Program for Improving the Health and Beauty of the Human Species," Endeavour 38, no. 1 (2013): 25. ${ }^{72}$ Clara Pinto-Correia and João Lourenço Montiero, 21.

${ }^{73}$ Pinto-Correia and Montiero, 24.
} 
colored human race; for others, the connection between climate, skin-color, and culture became a scientific endorsement of exploitation. These vexed debates colored other questions in natural history, most significantly the debate over polygenism and monogenism, which, in its own way, was a debate over what it meant to be human and who could fully claim that title.

2. The Body Electric: Sensibilité, Vital Fluids, and the Medicalization of Emotion

Recently named the Ambassador to France, John Adams, founding father of the fledgling United States, was invited to a dinner party in Bordeaux. During the meal, an attractive French woman asked him a question that upset his Protestant sensibilities. Later on Adams recorded the event in his diary, stating that the woman asked him if he knew "how the first couple found out the art of lying together." Less witty than the previous ambassador, Benjamin Franklin, Adams answered the indelicate question with a scientific analogy: "I rather thought it was by instinct, for there was a physical quality in us resembling the power of electricity or of the magnet, by which when a pair approached within striking distance they flew together like the needle to the pole or like two objects in electric experiments." To which the lady allegedly responded "well, I knew not how it was, but this I know—it is a very happy shock." ${ }^{.74}$

This was not a lone episode in French culture, nor is it terribly unique, except perhaps for the discomfort it caused the famous narrator. Throughout the middle decades

\footnotetext{
${ }^{74}$ Adams' autobiographical quote is presented in Michael Lynn, Popular Science and Public Opinion in Eighteenth-Century France (Manchester: Manchester University Press, 2006), 43.
} 
of the eighteenth century and through the early years of the French Revolution, the mental connection between sex and science appears in a multitude of contemporary sources. Public experiments such as the electric kiss appeared to be quite popular at scientific demonstrations, especially among young women: a dimmed room, an electrified boy, and a pretty girl demonstrated the power of the vital and subtle fluid of electricity, creating a kiss that neither the participants nor the audience would ever forget. ${ }^{75}$

Less common but at least as memorable was the large-scale experimententertainment put on for Louis XV, in which the Abbé Jean-Antoine Nollet passed an electrical current through 180 of the king's royal guards. Later, the experiment was recreated with 200 Carthusian monks pulled from a nearby monastery at the king's pleasure. These experiments were all well and good, the savants agreed, but what about eunuchs? How would electricity pass through the emasculated body? Intrigued, Louis XV ordered three of the castrati from his private company to undergo the same experiment. To the surprise of some and the pleasure of others, the castrati experienced the same shock as their virile counterparts. ${ }^{76}$ Seen in light of the eighteenth-century debates over the nature of electricity and its complicated role in the body, these instances are also part of a broader debate over this mysterious 'vital fluid' and our understanding of human sensation and emotion.

In many ways, this "Long Eighteenth Century" was the century of sensation. Categorized as voluptuous, emotional, and imaginative by many modern scholars, men

\footnotetext{
${ }^{75}$ Lynn, 31.

${ }^{76}$ Lynn, 2.
} 
and women in the eighteenth century saw the rise of the modern novel and the Rococo grandeur of art and architecture during the long reign of Louis XV. 'Feelings' often referred to as sentiments or sensibilities (sensibilités in French), were considered both purely internally-generated and also based on outside sensation. These concepts stand at the heart of much of the artistic, scientific, and philosophical endeavors of the period. ${ }^{77}$ For Enlightenment natural philosophers and physicians, sensibility was not only a legitimate way to comprehend the world, it was a field of inquiry as well.

If the Encyclopédie is any indication, the questions surrounding the nature of electricity — its generation and its utility — and the mechanisms of sensibility were a significant part of the scientific enterprise in the mid-eighteenth century. These inquiries created electrical medicine and Mesmerism, and then sparked a backlash against both. After a lengthy and contentious investigation into the matter, a royal commission determined that electrical medicine and Mesmerism were fraudulent practices. Mesmerism hijacked the imagination and undermined the trustworthiness of bodily sensation. ${ }^{78}$ In the end, the commissioners investigating these practices decided that they were inutile, and that they tricked men and women into believing that they were healed when, in fact, they were not. In other words, mesmerists and charlatans had used one of

\footnotetext{
${ }^{77}$ Riskin, 7. The histories of emotion and sensation have gained traction in recent years, and many studies touch on the new, biologically-focused theories of sensibility in the eighteenth century. Three works of particular interest are: Paul Goring, The Rhetoric of Sensibility in Eighteenth-century Culture (Cambridge: Cambridge University Press, 2005); Adela Pinch, Strange Fits of Passion: Epistemologies of Emotion, Hume to Austen (Stanford: Stanford University Press, 1996) Anne C. Vila, Enlightenment and Pathology: Sensibility in the Literature and Medicine of Eighteenth-Century France (Baltimore: Johns Hopkins University Press, 1998).

${ }^{78}$ Riskin, 217.
} 
the most human of all our mental faculties against their victims: they had manipulated their patients' imaginations.

Like electricity, sensibility was a new conceptual framework for understanding living organisms in nature. As with most of the broader themes of the Enlightenment discourses on nature, humanity, and the arts, it is only possible here to offer a brief overview. Montpellier-trained physician Henri Fouquet penned the Encyclopédie's article "Sensibilité, Sentiment," which spans an impressive 14 pages in the original edition. His article begins with a fairly straightforward definition:

SENSIBILITY, FEELING, (Medicine) the faculty of feeling, the sensory principle, or the same feeling of the parts, the basis \& preservative agent of life, animality par excellence, the most beautiful, the most singular phenomenon of the Nature, \& c.

Sensibility is in the living body, a property which certain parts have of perceiving the impressions of external objects, and consequently producing motions proportioned to the degree of intensity of this perception. ${ }^{79}$

For Fouquet, sensibility was everything, the pervading, all-encompassing basis of sentient life. The physician was one of hundreds, if not thousands of Enlightenment authors who put pen to paper to explore, explain, and debate sensibility; what it was, how it worked, and what its ramifications were for religion, philosophy, and medicine.

The medical school at Montpellier, France, produced some of the most forwardthinking work on the subject. Aside from Fouquet, physician Theophile de Bordeu combined the new theories on sensibility with the local flavor of vitalism, a medical

\footnotetext{
79 "SENSIBILITE, SENTIMENT, (Médecine) la faculté de sentir, le principe sensitif, ou le sentiment même des parties, la base \& l'agent conservateur de la vie, l'animalité par excellence, le plus beau, le plus singulier phénomène de la nature, \&c. La sensibilité est dans le corps vivant, une propriété qu'ont certaines parties de percevoir les impressions des objets externes, \& de produire en conséquence des mouvemens proportionnés au degré d'intensité de cette perception. Henri Fouquet, "Sensibilite, Sentiment [Médecine]," in The ARTFL Encyclopédie, vol. 15, p. 38.
} 
philosophy born in Montpellier. Vitalism situated the seat of sensibility in the visceral organs instead of the head; each organ, Bordeu believed, had its own proper sentiments, which spoke to its neighbors though the mucous membranes between organs. This socalled animal economy - the complex system of nerve and muscle fibers, interconnected with the organs, imbued the body with its inherent, life-giving sensibility. ${ }^{80}$

In the field of physiognomy, this trend towards understanding the physical bases for emotion was especially strong. ${ }^{81}$ Discovering the way in which the body worked, the relationships between thoughts and actions, emotions and physical experiences, was one of the hallmarks of eighteenth-century medicine. For almost two thousand years, the Galenic humoral theory served as the guide for medical care and for medicophilosophical theories on the nature of the body and the way it worked. In this system, the body was a hierarchy with corresponding fluids: the most refined fluids rested in the head and contributed to intellectual pursuits, the vital functions of organs and fluids in the chest mirrored their emotional and spiritual functions, and the lower region was the seat of sexual passion, ruled by the impure fluids of the liver and the viscera. ${ }^{82}$

As the mechanical model of the body took hold in the seventeenth century, it was not until the eighteenth that the ancient model was replaced by what German scholar Albrecht Koschorke has called the "shift from 'body-as-vessel' to 'body as-system,"” replacing the hierarchy of bodily sections with the concept of the nervous system, which

\footnotetext{
${ }^{80}$ Peter Hans Reill, Vitalizing Nature in the Enlightenment (Berkeley: University of California Press, 2005), 132-33. Eighteenth-century vitalism is a fascinating subject. For additional background, see Elizabeth A. Williams, A Cultural History of Medical Vitalism in Enlightenment Montpellier, History of Medicine in Context (Burlington: Ashgate, 2003).

${ }^{81}$ Outram, 47.

${ }^{82}$ Albrecht Koschorke, "Physiological Self-Regulation: The Eighteenth-Century Modernization of the Human Body," MLN 123, no. 3 [German Issue: Selbstregulierung als Provokation] (April 2008): 470.
} 
filled the entire body with a system of nerves, ruled not by humors but by an almostineffable vital fluid that affected—and was affected by—human emotions. ${ }^{83}$ The eighteenth-century body became a self-regulating, self-actualizing system of nerves filled with a fine, fluid-like substance. ${ }^{84}$ The idea of an electrical substance was certainly well regarded by the Enlightenment community of scientists. In the article "Électricité" from the Encyclopédie, professor of philosophy and science and member of the Academie des sciences Louis-Guillaume Le Monnier states that

This word signifies, in general, the effects of a very fluid and subtle material, different in its properties, from all the other fluids which we know; that we have recognized it as capable of uniting with almost all bodies, but some of them more preferably than others; which appears to move with a very great speed, according to particular laws; and which produces by its motions very singular phenomena. ${ }^{85}$

A part of nature, and yet one that does not follow its laws, at least as they were understood in the middle of the eighteenth century. For the philosophes, this was certainly part of the appeal to study electrical phenomena and learn to harness its awesome and destructive power.

Debates over the exact nature of this fluid are, in many ways, at the heart of the controversies surrounding medical electricity and Mesmerism. Like the mysterious nervefluid, electricity was usually considered a fluid as well. In his 1787 essay on electricity, Englishman George Adams, citing a variety of continental theorists and practitioners,

${ }^{83}$ Koschorke, 482-83.

${ }^{84}$ Koschorke, 484.

85 "Ce mot signifie en general, les effets d'une materiere très-fluide \& très subtile, différente par ses propriétés, de toutes les autres matieres fluides que nous connoissons; que l'on a reconnue capable de s'unir à presque tous les corps, mais à quelques - uns préférablement à d'autres; qui paroît se mouvoir avec une très - grande vîtesse, suivant des lois particulieres; \& qui produit par ses mouvemens des phénomenes très singuliers." Louis-Guillaume Le Monnier, "Électricité," in The ARTFL Encyclopédie, vol. 5, p. 469. Details of Le Monnier's life (203-04), and those of many other encyclopedists can be found in Frank A. Kafker and Serena L. Kafker, The Encyclopedists as Individuals: A Biographical Dictionary of the Authors of the Encyclopédie (Oxford: Voltaire Foundation, 1988). 
continuously refers to electricity in this way. The first lines of the introduction, "A Summary View of the General Principles of Electricity: Of Electricity, of Electrics, and Non-Electrics," prepare the reader for his lengthy discussion of the subject. He states, "There is a natural agent or power, generally called the electrical fluid, which by friction, or other means, is excited, or brought into action. This action is manifested to our senses by what are termed electric appearances." ${ }^{\prime 66}$ Electricity, therefore, is a sensible fluid that makes itself seen - and felt - through the manipulation of objects imbued with its power. Like the voice of the castrati, electricity was a natural force that could be manipulated, enhanced, and harnessed by man to produce incredible effects.

Adams' lengthy treatise includes an entire chapter on therapeutic uses of electricity, entitled "Of Medical Electricity," which he begins as follows:

The Abbé Nollet says that he received more pleasure when he discovered that the motion of fluids in capillary tubes and the insensible transpiration of animated bodies were augmented by electricity, than any discovery he had made; because they seemed to promise such abundant advantages to mankind, when properly applied with a skillful hand. ${ }^{87}$

According to Adams, then, the French physicist's joy comes from the utility of his discovery. Whether the Abbé truly made this statement or not, other physicians dabbling in medical electricity and, later, in Mesmerism, touted the utility of their arts for both the individual and the social body as well. The English translation of M. Caullet de Veaumore's Mesmer's Aphorisms and Instructions, printed in London in 1785 suggests a similar claim to utility: "III. There are several ways to ascertain [the universal fluids], and

\footnotetext{
${ }^{86}$ George Adams An essay on electricity... (London, 1787), xi. There are many sources on the subject written by French authors as well.

87 Adams, 297.
} 
make them subservient to mankind." This appeal to the human senses was a common theme among supporters of therapeutic electricity.

Natural philosophers and physicists continued to debate on the fundamental nature of the electric fluid, but the majority of its proponents agreed that it was everywhere. Adams states:

Electricity is an active principle, which is neither generated not destroyed; which is every where and always present, though latent and unobserved and is in motion by night and day, to maintain an equilibrium that is continually varying. To give one instance, among many, is has been shewn, that the rain that descends in a storm is strongly impregnated by electricity, and thus brings down what the heated vapors carried up into the air. ${ }^{88}$

According to the work of historian of science Geoffrey Sutton, investigations into the relationship between the vital fluid of the body and electric fluids found in nature were widespread during this time. Investigations into bodily vitality and fertility focused on geographic location and, therefore, on climate and weather patterns as well. Physicists like Pierre Bertholon de Saint-Lazare, who studied menstrual cycles, among other medical mysteries, used meteorology to explain common medical conditions as well as quotidian reactions to changes in the weather; in his study, he posited that the moon's position relative to the earth changed the quality and quantity of electric fluid, which in turn affected women's cycles. ${ }^{89}$ Connections like these were common in the work of many natural philosophers, whether they believed in the effectiveness of Mesmerism or not. In their effort to understand both the human body and the "universal fluid," as Mesmer called it, physicists used empirical methods to elicit the connections between this

\footnotetext{
${ }^{88}$ Adams, 299.

${ }^{89}$ Geoffrey Sutton, “Electric Medicine and Mesmerism," Isis 72, no. 3 (September 1981): 382.
} 
singular force of electricity, weather, and the state of health (or disease) within the human body. ${ }^{90}$ Inferring a relationship between weather and health, therefore, ultimately led many — like the Mesmerists and proponents of electric medicine — to posit a close and useful relationship between electricity and health, if only mankind could harness the power that surrounded and filled them.

The relationship between imagination and electrical medicine was problematic, and varied depending on the proponent's ideological bias. For Adams, imagination did not detract from the ultimate efficacy of electrical therapy. In fact, a lack of electrical fluid dulled the mind and the senses; stated that as the science advances, physicists and physicians can expect that:

What we call sensibility of the nerves, and many other diseases ... are owning to the bodies being possessed of too large or too small a quantity of this subtle fluid, which is perhaps the vehicle of all our feelings. It is known, that in damp and hazy weather, when this fire is blunted and absorbed by the humidity, it's [sic] activity is lessened, and what is collected is soon dissipated, then our spirits are more languid, and our sensibility is less acute. ${ }^{91}$

Like the ancient physicians' exhortations to balance the humoral fluids for the sake of bodily health, the electric enthusiasts recommended the maintenance of the subtle fluids to keep the mind and the senses in proper working order.

Unlike their detractors, proponents of Mesmerism and electrical medicine believed that imagination could be a useful component of healing practices. In the introduction to Mesmer's Aphorisms, ostensibly written by Veaumore, the author assures his readers of the veracity of Mesmer's claims by dismissing the criticisms that were

\footnotetext{
90 Sutton, 392.

91 Adams, 304.
} 
often lodged against the therapy. "Every day I heard of the wonderful phaenomena [sic] it produced, and I was convinced it deserved the attention of all Philosophers. I was not, however, quite inclined to believe them; they were so surprising, that I thought them the production of enthusiasm." ${ }^{\prime 92}$ And yet, based on his observation of Mesmeric therapies, Veaumore tells us that "the symptoms however I daily saw around me, did not make me conclude that, because I felt nothing, the others must be only exclusions, visionaries, or hypochondriacs. ${ }^{93}$ In other words, an overabundance of imagination was not the responsible for the near-miraculous cures generated by the manipulation of the subtle electric fluid.

Interestingly, in the body of the text itself, Mesmer extolls the virtues of his patients' imagination, stating:

$[\mathrm{P}]$ ersons of strong imagination hear a noise sooner than others, and I have known one that proclaimed the sound of a French horn a quarter of an hour before I could, if some are affected by a crisis, they will find in different sorts of meat a variety of fragrant particles, and enjoy a flavor unknown to those that are in a common state of body. ${ }^{94}$

In other words, Mesmer connected imagination, usually considered an internal world created by the mind, to be generated by the crisis created by the electric fluids.

Sensibility and veracity are not mutually exclusive for Mesmer. Indeed, according to the Aphorisms, those who are "very sensible" are simply attuned to a slightly different level of reality due to the abundance of the subtle electric fluids within their body. $\mathrm{He}$ states that his patients, upon eating even the simplest substance, like bread, reported to

\footnotetext{
${ }^{92}$ Mesmer, iii. "Enthusiasm" was second only to being a "man of system" in Enlightenment insults. For the latter, see Riskin.

${ }_{93}^{93}$ Mesmer, $v$.

${ }^{94}$ Mesmer, 30-31.
} 
him that they could taste distinct particles, like the flour and the water each as its own minute body, which produced sensations that had the ability to overcome the eater, and fill his or her mind with intense yet inexpressible ideas. ${ }^{95}$

Others, he reports, could "smell at a great distance, and even thro' wainscot doors, and others will distinguish odors that compose a perfume a perfume all at once, so great is their faculty of smelling." ${ }^{96}$ The most telling word in this sentence, faculty, neatly encompasses Mesmer's views expressed in this document. While the idea of sensing the atoms (in the pre-modern sense) of a compound substance like food or perfume seems ludicrous to most people — and indeed, to many of the members of the royal commission that investigated Mesmer's activities—-here, such abilities were tied to imagination through the senses, and the action of sensibility. Imagination, therefore, is simply a sign that a person is sensible to things that others are not, including the electrical fluids that permeate the universe.

Whether shocking the body with electric jolts or exposing it to the powerful vibrations of music, the eighteenth-century public was obsessed with its own sensibility. And, while human beings experiencing the same situation will have different reactions, physicians, philosophes, and naturalists clearly believed that like groups of peoplewomen, or Hottentots, or Italian men, for instance — shared a set of internal configurations based on gender, geography and climate that made their nerves and fibers respond to outside stimuli in a similar way. The castrati, while an artificially-created

\footnotetext{
${ }^{95}$ Mesmer, 31.

${ }^{96}$ Mesmer, 31 .
} 
group, both retained the common markers of the Italian race and inherited a set of distinct characteristics, as they had been altered in such a way as to change the very balance of their vital fluids. These men had become, in essence, their own race-species through the extreme manipulation of their bodies. Set apart from all 'natural' races of men by their physical form, the castrati developed a set of characteristics that were unique to their species, a concept we will examine in the next chapter. As with any other race, this was seen as the 'natural' way for a given group to act, and responding otherwise was against one's inherent natural sensibility. In this way, the sciences de l'homme took the reins of dictating correct action and response from society and placed them firmly in Nature's hands. 


\section{Chapter Two}

\section{Of Monsters and Men: (Hu)men on the Margins}

Bodily Deformity is visible to every Eye; but the Effects of it are known to very few; intimately known to none but those, who feel them; and they generally are not inclined to reveal them. As therefore I am furnished with the necessary Materials, I will treat this uncommon Subject at large: and to view it in a philosophical Light is a Speculation, which may be useful to Persons so Oddly (I will not say unhappily) distinguished; and perhaps not unentertaining to others.

—William Hay, Deformity: An Essay, 1754

Foucault's concept of the Other, summarized, can be taken as the following: groups define themselves by what they have and others lack. Historians of disability have embraced poststructuralism as a framework for dis/ability, but as with discussions of race, rhetoric of sameness vs. difference necessarily creates in-groups and out-groups. More recently, disability studies have embraced historicism, seeking to locate the meaning of disability within specific places and times. Scholars are once again embracing the idea of 'variability' and 'variation' touted by early eighteenth-century writers. Within this framework, they seek to do away with the dis/abled binary and embrace the endless subtleties of humanity. ${ }^{97}$

The concept of variability also does away with the juggernaut of 'disability' as an umbrella term which covers any and all bodies that significantly deviate from the norm. In other words, variability notes that blindness or deafness, loss of limb or function, are not the same, even among those who are diagnosed with the same condition. By highlighting the absolute individuality of each experience, there is no longer a disability

\footnotetext{
${ }^{97}$ Chris Mounsey, Introdution to The Idea of Disability in the Eighteenth Century, ed. Chris Mounsey, Transits: Literature, Thought, \& Culture 1650-1850 (Lewisburg: Bucknell University Press, 2014), 1.
} 
or able-bodiedness, but simply a wide and varied range of human experience. ${ }^{98} \mathrm{We}$ are each of us "the same only different." $" 99$ Lest this seem to critics an attempt to lessen the physical and emotional pain of the differently-abled, variability studies focus on three analytical elements: capacity, capability, and encounter. These encompass the experience between subject and the outside world, as well as the relationship between body and mind. ${ }^{100}$

In the eighteenth century, however, the binary construction was the primary methodology for determining what normal biology was like within a given species. Morphology, the study of structure and variation, and teratology, the study of congenital deformations, found new life in the sciences de l'homme and the rapidly advancing fields of physiology and medicine. These sciences dealt with the (often fine) line between normal and abnormal, challenging pre-Enlightenment views on 'monstrous' bodies, their meaning, and their naturalness or lack thereof. Monstrous or deformed bodies were compared and contrasted with those whose physical abnormalities were the result of human intervention, such as the castrati.

In this chapter, we first must understand the relationship between 'natural' and 'monstrous' examples of a species, where these two concepts intertwined, and how the monstrous abnormalities of nature moved out of the realm of the marvelous and into the realm of science, both academic and popular. Having examined monstrosity in the

\footnotetext{
${ }^{98}$ Mounsey, 17.

${ }^{99}$ Mounsey, 18.

${ }^{100}$ Mounsey, 18-19.
} 
abstract, we turn to examples of human monsters in order to understand how different ‘species' were classified. ${ }^{101}$

Lastly, we examine the castrati as a monstrous species: man-made and distinctly unnatural, they still had a nature that was particular to them alone. Here, we follow the average life of the castrati through a prosopographical sketch, delving into the roots of their deformity and disability on the social and biological level. We'll also examine the role of bodily mortification and sacrifice, both overarching themes in Catholicism, as part of the cultural context that created the castrati and allowed them to thrive. For the castrati, their disability was also the cause of their great ability, namely, their piercing, powerful voice. Were the castrati man-made monsters, or miracles? For most philosophers and opera patrons, the answer was both, to varying degrees.

1. Farther from the Truth of Nature: Taxonomized and Anti-marvelous Monstrosity

There is something inherently derogatory about calling someone a monster, defining them by their most inhuman qualities. However, the use of the term 'monster' in regard to human beings has shifted in the last hundred years especially. Today, we reserve the term for people who demonstrate their hideous inhumanity through words and actions instead of physical characteristics. In other words, they are not born looking like a monster, they make the choice to behave like one. Equating monstrosity with bad behavior or questionable morals dates back to at least Aristotle, and was generally

\footnotetext{
${ }^{101}$ Including those born physically or mentally different, those who were too natural, and those who became monsters due to misfortune.
} 
referred to as 'moral deformity' in eighteenth-century treatises. Moral deformity was not divorced from the body, however, as philosophers often grounded their understanding of morality in the corporeal senses and passions. ${ }^{102}$

Likewise, for at least a century before Keats' pronouncement that "truth is beauty, beauty truth" eighteenth-century philosophical texts sought to understand the relationship between beauty and morality. During the eighteenth century, like the twenty-first, 'monster' was a polysemous term. Part of the Enlightenment enterprise was categorizing the various types of monstrosity—physical, moral, and aesthetic — to discover their interrelationships. ${ }^{103}$ Despite the best efforts of the philosophes, then, concepts of monstrosity were not settled. Like the castrati, the concept of physical and moral monstrosity served as a cultural site of anxiety where philosophy, natural history, theology, and the arts conversed and competed to provide the ultimate definition of monstrosity. ${ }^{104}$

Here, though, we must first understand the term 'monstrosity' and its relatives from a medico-scientific perspective. In reviewing the corresponding articles in the Encyclopédie, we see that the encyclopedists focused on the physical aspects of these

\footnotetext{
${ }^{102}$ Paul Kelleher, "Defections from Nature: The Rhetoric of Deformity in Shaftesbury's Characteristics," in The Idea of Disability in the Eighteenth Century, ed. Chris Mounsey, 73. There were other cases, however, where nature was too natural, such as the wild children who sporadically wandered out of the European forests. For a fascinating look at the wild children, see Julia V. Douthwaite, The Wild Girl, Natural Man, and the Monster: Dangerous Experiments in the Age of Enlightenment (Chicago: University of Chicago Press, 2002). Other useful works on this topic include: Erica Fudge, At the Borders of the Human: Beasts, Bodies, and Natural Philosophy in the Early Modern Period (New York: Palgrave, 1999) and Felicity Nussbaum, The Limits of the Human: Fictions of Anomaly, Race, and Gender in the Long Eighteenth Century (Cambridge: Cambridge University Press, 2003).

${ }^{103}$ Andrew Curran and Patrick Graille, "The Faces of Eighteenth-Century Monstrosity," EighteenthCentury Life 21 no. 2 (1997): 11.

${ }^{104}$ Curran and Graille, 3.
} 
words, as botanical and zoological phenomena or medical afflictions. ${ }^{105}$ For the

encyclopedists, the two latter categories explicitly included human beings, placing our

species firmly within nature alongside our fellow animals.

The Encyclopédie divides its discussion of monstrosity into two articles as

described above. In both articles, monstrosity can be either the too-muchness, or notenoughness of parts: flowers sprouting extra branches, or feet with too few toes. The Chevalier de Jaucourt's botanical definition comes first alphabetically: "In botany, we call monsters singularities that are outside the ordinary course." 106 Jean-Henri-Samuel Formey, the former Calvinist clergyman who wrote on many subjects for the Encyclopédie, penned the article on zoological monstrosity, ${ }^{107}$ imparting his definition with a more philosophical-theological flair:

[An] animal which is born with a conformation contrary to the order of nature, that is to say with a structure of parts very different from those which characterize the species of animals from which it comes ... In all species we often see the birth of misshapen animals, animals that lack some parts or have some parts too much. ${ }^{108}$

\footnotetext{
${ }^{105}$ The word "biology" in the modern sense - the study of living organisms - was not a part of the mideighteenth century scientific lexicon. The division of living things into two groups, plant and animal, follows the ancient tri-partite division of the knowable world that persisted in eighteenth-century natural history: animal, vegetable, and mineral. In this context, then, we can consider "zoology" to be the forerunner of field of biology, or "proto-biology."

106 "On nomme monstres en Botanique des singularités qui sont hors du cours ordinaire." Louis, Chevalier de Jaucourt, "Monstre [Botanique]," in The ARTFL Encyclopédie, vol. 10, p. 671.

${ }^{107}$ Formey's role in the creation of the Encyclopédie is a fascinating one. After leaving his post as a clergyman in Berlin, he became a professor of philosophy at the College François as well as a fellow (and historiographer) of the Berlin Académie Royale. Formey was 1800 pages deep into a philosophical dictionary of his own when he learned of the Encyclopédie project, and ultimately sold his manuscript to Diderot and D'Alembert for inclusion in their project. Kafker and Kafker, 140-43.

108 “[A]nimal qui naît avec une conformation contraire à l'ordre de la nature, c'est-à-dire avec une structure de parties très-différentes de celles qui caractérisent l'espece des animaux dont il sort ... Dans toutes les especes on voit souvent naitre des animaux contrefaits, des animaux à qui il manque quelques parties ou qui ont quelques parties de trop." Jean-Henri-Samuel Formey, "Monstre [Zoologie]," in The ARTFL Encyclopédie, vol. 10, p. 671.
} 
Contrary to the order of nature. In other words, for Formey, the monstrous body was unnatural, disordered, put together in an incorrect way. More important, perhaps, was the idea that the terms monster and monstrosity were only applied to organisms that were inherently different from birth.

Formey devotes the bulk of his article to the debate on the origin of monstrosity in animals, whether it is the result of inherent monstrosity of the egg, or due to the very Aristotelian-inspired "accidental causes." He then presents an account of a debate within his academy of science in Berlin, in which two well-respected natural philosophers, Messrs. Lemery and Winslow, ${ }^{109}$ debate their relative positions on the subject. Noting that the debate remained unsettled and neither was convinced of the other's position, Formey caps his summary of the debate with a nod to its metaphysical implications: "Finally we came to metaphysical reasons. One found it scandalous to think that God had created originally monstrous germs; the other believed that it was to limit the power of God, to restrain him to a great regularity and uniformity." ${ }^{110} \mathrm{God}$, then, was still at the heart of this particular question for Formey and his compatriots, though the moral aspect remained undiscussed.

The Chevalier du Jaucourt also penned the Encyclopédie article on prodigies in the ancient world, combining political history, natural philosophy, and some strong opinions on the opinions of both ancient and modern societies. He notes two classes of ancient prodigies, the first being what he calls "Pagan miracles" which are contrary to

\footnotetext{
${ }^{109}$ Unfortunately, we learn nothing about these natural philosophers here aside from their names.

110 "Enfin on en vint aux raisons métaphysiques. L'un trouvoit du scandale, à penser que Dieu eût créé des germes originairement monstrueux : l'autre croyoit que c'étoit limiter la puissance de Dieu, que de la restraindre à une régularité \& une uniformité très grande." Formey, vol. 10, p. 671.
} 
nature because they are supernatural. He dismisses the stories on this class of prodigy entirely, as they are not only against nature but completely impossible within her confines. He offers this explanation of the second class of prodigy:

The prodigies of the second class are purely natural effects, but which, arriving less frequently, appearing contrary to the ordinary course of nature, have been attributed to a supernatural cause by the superstition of men frightened at the sight of these unknown objects . . I place almost all these prodigies under this last class [of two], being persuaded that the greater part of these marvelous events are, by reducing them to their true value, only natural effects, often even quite common. When the minds of men are once mounted on the superstitious tone, everything becomes in their eyes prodigy and miracle. ${ }^{111}$

His definition of prodigies echoes almost word for word his definition of botanical monsters. He gives examples, including all plant and animal 'monsters' as well as extraordinary weather and atmospheric phenomena. A two-headed calf, a child born with a vestigial tail, and the aurora borealis were therefore bound together for the superstitious by their strangeness, and for modern natural philosophers — including Jaucourt—by their ability to be explained through rational thinking.

Several other Encyclopédie articles hinted at prodigies and monstrosity without explicitly calling the subjects of inquiry monstrous, or using the word 'monster' in their examinations of physical anomalies. Jaucourt's Encyclopédie articles on deformity and jeux de la nature only mention human beings. The article on jeux de la nature defines the term as "a conformation of some, or several of its solid parts, different from that which

\footnotetext{
111 "Les prodiges de la seconde classe sont des effets purement naturels, mais qui arrivant moins fréquemment \& paroissant contraires au cours ordinaire de la nature, ont été attribués à une cause surnaturelle par la superstition des hommes effrayés à la vûe de ces objets inconnus ... Je range presque tous ces prodiges sous cette derniere classe, étant persuadé que la plus grande partie de ces évenemens merveilleux ne sont, en les réduisant à leur juste valeur, que des effets naturels, souvent même assez communs. Lorsque l'esprit des hommes est une fois monté sur le ton superstitieux, tout devient à leurs yeux prodige \& miracle." Louis, Chevalier de Jaucourt, "Prodige physique," in The ARTFL Encyclopédie, vol. 13, p. 422.
} 
are called natural, because it presents itself ordinarily." 112 This is perhaps the most technical article of the group, presenting eight case studies of babies—plus a few children and one adult—whose physiological abnormalities were discovered post-mortem via autopsy; Jaucourt notes that some subjects presented with external deformities, though his focus here is on the deformity or absence of internal organs, bones, musculature, or tissue. ${ }^{113}$ Interestingly, the article on jeux de la nature contains summaries of actual case studies; perhaps they offered the only truly unique accounts. Based on the average age of the deceased at time of death and the reported severity of their conditions, it seems clear that classification as a jeux de la nature was far more extreme than that of relatively common birth defects, which are the main focus of Jaucourt's article on deformity. It should not be lost on the modern reader, then, that some degree unnaturalness was so common as to be rendered unremarkable to the eighteenth-century naturalists - an idea that certainly worked to undermine the binary natural-unnatural, normal-deformed framework. ${ }^{114}$

Where Formey focuses on the metaphysical implications of monstrosity in his definition, Jaucourt notes the ways in which physical difference (deformity) affects the afflicted person's ability to function in normal society:

Under this generic word is understood every figure of the parts or organs of the human body, which moves away from the natural, to the point of preventing its

\footnotetext{
112 "[U]ne conformation de quelques-unes, ou de plusieurs de ses parties solides, différentes de celle qui est appellée naturelle, parce qu'elle se présente ordinairement.” Louis, Chevalier de Jaucourt, “Jeu de la nature," in The ARTFL Encyclopédie, vol. 8, p. 532.

113 Jaucourt, “Jeu de la nature," vol. 8, p. 533.

114 Javier Moscoso, "Monsters as Evidence: The Uses of the Abnormal Body during the EighteenthCentury," Journal of the History of Biology 31, no. 3 (Autumn 1998): 360-361.
} 
functions, or even only to cause pain in the eyes of those who are not accustomed to it. $^{115}$

Like Formey, then, Jaucourt again sees a body that is formed differently as less natural, farther from the truth of nature, than one that is average.

While monstrosity is divided between too many parts or not enough, Jaucourt divides deformity into groups based upon when the shift from normalcy occurs, moving one from human to monster. In other words, those born different, and those whose deformities are caused by the myriad vagaries of living such as accidents, illness, natural or man-made disasters, and what we now consider lifestyle diseases, such as malnutrition. No matter what the cause, Jaucourt notes, deformity creates difficulty using the affected body part(s) in the traditional way, if the part has any function at all. ${ }^{116}$ For Jaucourt, understanding the level of functionality is more important in defining the term than taxonomizing the types of differences themselves.

Physical difference is further discussed in physician Gabriel-François Venel's article on infirmity, which gives this definition of the term:

The absolute privation, the considerable diminution, or the depravity of the action of the organs of the senses, of generation, of voluntary movement, when these defects are constant, are infirmities; or that they depend on some lesion particular to these subjects, very well constituted elsewhere. ${ }^{117}$

\footnotetext{
115 "[O]n comprend sous ce mot générique toute figure des parties ou des organes du corps humain, qui s'éloigne de la naturelle, au point d'en empêcher les fonctions, ou même seulement de faire de la peine aux yeux de ceux qui n'y sont pas accoûtumés." Louis, Chevalier de Jaucourt "Difformité [Médecine]," in The ARTFL Encyclopédie, vol. 4, p. 990. Some deformities could be hidden, and others remedied at least in part. For more on this subject, see David M. Turner, and Alun Withey, "Technologies of the Body: Polite Consumption and the Correction of Deformity in Eighteenth-Century England," Journal of the Historical Association 99 no. 338 (December 2014).

116 Jaucort, "Difformité," vol. 4, p. 990.

117 "La privation absolue, la diminution considérable, ou la dépravation de l'action des organes des sens, de la génération, du mouvement volontaire, lorsque ces vices sont constans, sont des infirmités; soit qu'elles dépendent de quelque lesion particuliere dans des sujets, très bien constitués d'ailleurs." Gabriel-François Venel, "Infirmité [Grammaire | Médecine]," in The ARTFL Encyclopédie, vol. 8, p. 708.
} 
In other words, a blind person who has two eyes, a deaf person who has two ears, or a person with normal sexual organs who cannot reproduce are considered infirm, but not deformed and certainly not monstrous. ${ }^{118}$ And, like Jaucourt's definition of deformity, infirmity could happen at different stages of life, indeed it should be expected as one ages. The main difference between the two terms, based on Venel's examples, is that the body parts (e.g., eyes, ears, penis, etc.,) retain their normal form but are unable to perform their given function. ${ }^{119}$

Like Jaucourt's article on deformity, Venel's definition of infirmity is classified as a medical article, placing it totally within the realm of anthropocentrism. So, while the zoological article on monstrosity referred to human beings as well as other animals, categorizing deformity and infirmity as (human) medical issues suggests these concepts were considered purely human affairs by the encyclopedists; whether this was requested by the writers or decided upon by Diderot and D'Alembert, we do not know. We certainly have evidence that human beings with deformities were referred to as monstrous, but the encyclopedists did not see fit to make such statements in their articles on human afflictions. In fact, they often went to great lengths to point out what was normal, or non-monstrous in a case study. ${ }^{120}$

Based on these articles, written by some of the most respected academic figures in Europe, it is clear that monstrosity, deformity, and infirmity were not synonymous terms. Taken together, they suggest that the general consensus among the philosophes was that what we today call physical disability — a term that is not used in the Encyclopédie-was

\footnotetext{
118 Venel, "Infirmité," vol. 8, p. 708.

119 We might include arthritis, constipation, and toothache among common infirmities as well.

${ }^{120}$ Moscoso, 356.
} 
not a simple binary, but a continuum of (un)naturalness that affected living beings to different degrees and stemmed from different causes. Historian of science Javier Moscoso suggests it is possible to divide them into two categories: those who conformed to a well-known pattern and therefore elicited little interest, and those who were abnormal even by the standard ideas of monstrosity, such as the jeux. ${ }^{121}$ Still, the main connection between them is that the afflicted fall outside of the normal, natural form for the human species.

Carl Linnaeus, the father of taxonomy, went so far as categorize them as a different species altogether: homo monstrous, which included all variations of human-like children born to human parents who presented with significant birth defects. By separating those born with deformities from the rest of humanity, Linnaeus used the trappings of scientific language and culture to stigmatize an already vulnerable segment of the human population. ${ }^{122}$ By defining and taxonomizing monstrosity and proclaiming it to be disordered and unnatural even as they noted its prevalence, encyclopedists, philosophes, and naturalists obliquely define what is representative of the natural, ordered world: "not this," they say.

$$
* * *
$$

Towards the end of his article on prodigies, Jaucourt notes that "The ancient historians were therefore right to mention these prodigies so often, and they could not foresee that there would be a time when men would only pay attention to them in order to

\footnotetext{
${ }^{121}$ Moscoso, 362-63. He describes the former as nature "replicating her own experiments."

${ }^{122}$ Phillip K. Wilson, "Eighteenth-Century 'Monsters' and Nineteenth-Century 'Freaks': Reading the Maternally Marked Child," Literature and Medicine 21, no. 1 (Spring 2002): 8. According to Wilson, the creation of this new species first appeared in 1758, part of the $10^{\text {th }}$ edition of the famed taxonomist's System Naturae per Regna Tria Naturae.
} 
seek the physical cause, and to satisfy a mild stir of curiosity." ${ }^{123}$ Where once the most learned men in Europe saw monsters and prodigies as messages from God, the modern learned man knew that the natural world could be fully explained through rational inquiry, and as such could be manipulated. For the eighteenth-century natural philosopher, aberrations in nature were no the longer sources of wonder they were even a hundred years earlier. ${ }^{124}$ If wonder persisted for some, the emotion was transferred from wonder at God's power to wonder of the natural world in all of its glorious, overarching regularity. Bernard Le Bovier de Fontenelle, Secretary of the Paris Académie des Sciences from 1697 to 1740 , was a great proponent of rational curiosity in his writings aimed at fellow natural philosophers as well as the elite class of lay readers. Fontenelle often attacked older notions that monsters and prodigies should get all the attention. Instead, he campaigned for the ordinary, near-endless abundance of commonplace miracles all around which could be known only through intense, disciplined, and rational study. $^{125}$

We see from Formey and Jaucourt's Encyclopédie articles that Fontenelle's dictum gained traction among his peers, but the lay public was a different story. Indeed, it was these first few decades of the eighteenth century where learned and popular scientific interests began to diverge. In their thorough and fascinating work on wonder and premodern science, historians of science Katharine Park and Lorraine Daston provide a

\footnotetext{
123 "Les anciens historiens ont donc eu raison de faire si souvent mention de ces prodiges, \& ils ne pouvoient prévoir qu'il y auroit un tems où les hommes n'y feroient attention que pour en rechercher la cause physique, \& pour satisfaire un léger mouvement de curiosité." Jaucourt, "Prodige physique," vol. 13, p. 423.

${ }^{124}$ Lorraine Daston, and Katharine Park, Wonders and the Order of Nature (New York: Zone Books, 2001), 305.

${ }^{125}$ Daston and Park, 324-25.
} 
telling example: in a 1736 sale catalogue listed their recent shipment of exotic seashells into separate categories for their two classes of customers. The first were unpolished "brute" shells listed for the naturalists (referred to as Physiciens), who exercised the "recreation of the mind" in order to understand the ordered variation of nature. The second group of shells were polished up for the lay collector (Curieux) who purchased these rare objects for their aesthetic value. This latter category, Daston and Park tell us, were "arrested by the pleasing surfaces of things," where old-fashioned wonder "bordered on stunned astonishment and did not trigger inquiry." 126 In other words, these curieux did not possess the correct "noble curiosity" which rejected the marvelous in order to truly understand that the wonder of nature went beyond beautiful colors and pleasing shapes. ${ }^{127}$

As the eighteenth century progressed, natural philosophers also sought to discard the idea of aesthetics as mere prettiness and replace it with notions of uniformity, simplicity, and utility. Much as they replaced frivolous curiosity for diligent inquiry, natural historians focused on the "pleasant regularity" of a well-ordered universe. ${ }^{128}$ Aberrations — whether botanical, geological, or zoological—aroused interest as objects which defined the boundaries of what was considered natural and what was not.

\section{$* * *$}

While they may not have had the same goals, both learned and lay audiences were fascinated by the display of monstrous bodies. Raree shows, as they were called in England, were as popular in the eighteenth century as they had been in the seventeenth

\footnotetext{
126 Daston and Park, 325-26.

${ }^{127}$ Daston and Park, 327; 331.

${ }^{128}$ Daston and Park, 355.
} 
(and would be up through the 1930s). These displays shaped conceptions of the human body in several ways. They taught the public how to see bodies by presenting them as a form of entertainment, while simultaneously providing physicians and naturalists easy access to anatomical specimens both living and dead. Like the Mesmerism craze and demonstrations of electricity we encountered in chapter one, these displays were therefore situated at the nexus of popular science and professional medicine, each group mutually informing the other. ${ }^{129}$

Some shows toured throughout Europe, while smaller ones might take up permanent residence in larger cities like London and Paris, where children and adults alike were either displayed on the street or tucked away into the side chambers of taverns or coffee houses. ${ }^{130}$ Some shows included living human beings alongside dissected and preserved remains, commonly referred to as "pickled," often of former living members of a raree troupe. While this certainly seems like a miserable, dehumanizing existence, those born with severe birth defects had few, if any, opportunities to make a living. ${ }^{131}$

Many of these performers had stage names, as was the case for Charles Byrne and Caroline Crachami, the "Irish Giant" and "Sicilian dwarf" respectively. ${ }^{132}$ One cannot help but draw a comparison to the castrati, who also adopted stage names and toured Europe; like raree show monsters, the castrati's anatomy was integral to their fame. For both homo monstrous and the castrati, otherness was a popular draw for the curious layman while simultaneously acting as a site of scientific curiosity. Lacking some normal

\footnotetext{
${ }^{129}$ Elizabeth Stephens, Anatomy as Spectacle: Public Exhibitions of the Body from 1700 to the Present, Representations (Liverpool: Liverpool University Press, 2011), 5.

${ }^{130}$ Wilson, 4.

${ }^{131}$ Wilson, 6.

${ }^{132}$ Stephens, 8 .
} 
human functions while far exceeding 'normal' men in others, the castrati were certainly monstrous by eighteenth-century standards. Using Linneaus' ontological framework, then, we turn next to the castrati as a species to examine their 'birth,' or the circumstances of their transformation into castrati, and their average life cycle.

2. The Capons of the Opera House: The Castrati as Monstrous Species

Similar to those whose disability was unnatural—due to illness or injury—castrati like Farinelli and his operatic brethren had existed for thousands of years before the castrati took to the royal courts and opera houses of Europe. Unfortunately, neither surgical method nor the responses toward the castrated male body had changed significantly since the time of Herodotus. In his influential work Traité des Eunuques, translated into English as Italian Love: Eunuchism Displayed, French jurist Charles Ancillon writes:

If they have sometimes been raised to the highest pinnacles of human Glory, and basked in the Sun-Shine of this World, the People look'd upon them as so many Erroneous Productions of the depraved and corrupted Minds of Princes, who elevated them to those high Stages of Honour, and when they appeared in Publick, they only increased and augmented the Hatred and Aversion the People had for them, who laughed at them amongst themselves, calling them old women \&c. ${ }^{133}$

Here, Ancillon refers to the castrated servants of an ancient empire, but many of these sentiments still held true in his own time. Created to serve at the pleasure of kings and opera patrons, the castrati of Europe met with a vast range of reactions, from pity and

${ }^{133}$ Charles Ancillon, Italian love: Or, Eunuchism displayed . . . 2nd ed. (London, 1740), 95-96. Eighteenth Century Collections Online. 
disgust to admiration and devotion. For many moralists their very existence was a sign of the debauched and effeminate state of European culture, while music enthusiasts viewed them as the pinnacle of artistic expression, who traded an ordinary existence for extraordinary abilities.

The castrated body had met with mixed reactions for millennia before Ancillon sat down to pen his legal treatise-cum-history, first published in 1707 and reprinted throughout the eighteenth century. It is not only the act of castration itself that is horrific for Ancillon, but the motives behind it: revenge, fear, and avarice, depending on the circumstances. ${ }^{134}$ From the twisted desires of the ancient Queen Semiramis to the greed of peasant families in Italy who sold their sons to the opera masters of Naples, the act of creating eunuchs showed, at least in the eyes of contemporary commentators, a lack of self-control and a violent, selfish temperament in those who caused them to be made.

In part one of Eunuchism Displayed, Ancillon, following in what Michel Foucault called the "taxonomic impulse" of the eighteenth century, describes and categorizes the various types of eunuchs, both historical and contemporary. ${ }^{135} \mathrm{He}$ divides them into four groups: those who were born without fully-formed genitalia, which he calls "absolutely and properly eunuchs;" those who have "been despoiled of all that which makes Man and his Virility," or men who have lost both penis and testicles; those whose testicles were deprived of blood, causing the organs to wither; and those he refers to as spadones, who were incapable of procreation either by slight birth defect or by temperament. ${ }^{136}$ The latter, he states, are not really eunuchs in the traditional sense. Rather, they are men who,

\footnotetext{
134 Ancillon, 41.

135 Outram, 68.

136 Ancillon, 14-17.
} 
by their cold humoral temperament, act more like their unfortunate brethren than those who take pleasure in women. ${ }^{137}$ Ancillon also shares his hope with the reader that this fourth type of eunuch may overcome his personal nature and, "by the Force and Help of Nature . . possibly be restored to that perfect State Nature at first intended them." 138 Here, 'nature' is both a force and a state of being, with the ability to right the wrongs of personal temperament so that the frigid man might fulfill his ultimate purpose which, for Ancillon, is procreation.

While castration itself was a long-standing practice throughout Asia and the Mediterranean, castrating boys to keep their soprano voices intact was a product of the early modern Catholic Church. In his 1973 article entitled "The Sacred Capons," historian of music Anthony Milner states that the first mention of a castrato performer in Rome dates from 1553, with the first unequivocal reference coming in 1599, when the keeper of the Sistine Diary notes two eunuchus priests had recently joined the choir. ${ }^{139}$ Since women were forbidden to sing in Catholic choirs, the higher parts had traditionally been sung by either boys or falsettos. Though historians are still debating why the change from falsetto to castrato occurred, by 1640 castrati were members of all the main cathedral choirs in Italy. According to Milner, it was this normalization of the castrated

\footnotetext{
${ }^{137}$ Ancillon, 17-18. Our author also mentions two more kinds of eunuchs in passing, which he calls "catachrestic" eunuchs, meaning men who hold positions of power traditionally given to eunuchs. For this type he gives mainly biblical and historical examples. The last type are simply men who desire to remain chaste, and are only eunuchs in the figurative sense, as they have no apparent physical or emotional conditions leading them to eschew sexual relations. Ancillon, 18-23.

${ }^{138}$ Ancillon, 17. While castrati were still considered male, there are a few recorded cases of intersex people undergoing surgery in order to "restore" them to their biological birth sex. One fascinating history on the subject is Carol A.B. Warren, "Gender Reassignment Surgery in the 18th Century: A Case Study," Sexualities 17, no. 7 (2014).

${ }^{139}$ Anthony Milner, “The Sacred Capons,” The Musical Times 114, no. 1561 (March 1973): 250.
} 
soprano in religious institutions which led to the popularity of castrati in the nascent field of opera. ${ }^{140}$

Catholic cannon law expressly forbade bodily mutilation as a form of worship or sacrifice, but Feldman notes that religious concepted surrounding the mortification of the flesh and religious sacrifice are intimately tied to the practice of castration in the early modern period. Early modern Italy was steeped in both Catholic and humoral-medical symbolism, the latter tying the young castrato's bloodletting to medical rituals of purification and regeneration, and the former to the crucifixion of Christ, whose physical sacrifice secured salvation for mankind. ${ }^{141}$ Bloodshed through castration, and the renunciation of ordinary life through the sacrifice of the generative organs, are common themes of many post-facto accounts of castratos' early lives. They speak of castration as a "sacred donation" to God, church, patrons, teachers, and even the opera-going public. ${ }^{142}$

Whatever the cause of a castrato's current state, castration produced a common set of side effects, which each individual would experience to differing degrees. Based on Feldman's scholarship, we know that in Italy at least, these castrations were likely carried out as bilateral herniotomies, which involved either crushing the testicles, compressing them until they atrophied, or excising through an incision in the scrotum; farm animals were castrated in the same manner. ${ }^{143}$ While this sounds barbarous in the extreme, contemporary literature tells us that, at least in some cases, the subjects were rendered

\footnotetext{
140 Milner, 50.

${ }^{141}$ Feldman, The Castrato, xiv.

142 Feldman, The Castrato, xii-xiii.

${ }^{143}$ Feldman, The Castrato, 7-8.
} 
unconscious via pressure applied to the jugular vein before the operation. ${ }^{144} \mathrm{~A}$ small comfort for the boys themselves, and a fact which likely relieved at least some guilt for the families, the surgeons, and, later, the castrati's admirers.

And so, with the cut of a knife, these pre-pubescent boys' bodies were altered at the biological level. In modern medicine, the lack of androgens such as testosterone is called hypoandrogenism, a form of hypogonadism, the latter of which can affect both men and women. Technically, the castrati's hypoandrogenism is today classified as primary hypogonadism as it was caused by the removal of the testicles. ${ }^{145}$ As a male child with hypogonadism aged, his body would take on certain tell-tale characteristics associated with the castrati in popular culture; large unruly body and high-pitched voice made the castrati easy to spot amongst a crowd.

Aside from the high voice and smooth faces and bodies, and could develop breast tissue (a condition called gynecomastia) or fatty tissue deposits around the hips and buttocks, creating a typically feminine figure. ${ }^{146}$ Fat could also collect on the eyelids, creating a swollen appearance that, along with the lack of facial hair, gave the appearance of a giant, round baby's head. ${ }^{147}$ The castrati were also likely to be taller than the average man, with abnormally long arms and legs compared to the length of the torso. Without

\footnotetext{
${ }^{144}$ Enid Rhodes Peschel, and Richard E. Peschel, "Medical Insights into the Castrati in Opera," American Scientist 75, no. 6 (November-December 1987): 581.

${ }^{145}$ Peeyush Kumar et al., "Male hypogonadism: Symptoms and treatment," Journal of Advanced Pharmaceutical Technology \& Research 1, no. 3 (2010): 298-99. Secondary hypogonadism is caused by problems with the pituitary or hypothalamus. In this case, the testicles do not receive the proper signals to release androgens.

${ }^{146}$ Feldman, The Castrato, 10-11.

${ }^{147}$ Peschel and Peschel, 582.
} 
the appropriate levels of testosterone, he would also have difficulty building muscle, making the long limbs appear thing and spindly. ${ }^{148}$

Several symptoms of male primary hypogonadism were actually advantageous for singing opera. For many castrati, the ribcage was broader than average, making more room for the lungs to expand as well as producing more space for sound to reverberate, both of which would help the voice carry in large opera houses. ${ }^{149}$ Similarly, and perhaps more importantly, inhibiting testosterone kept the larynx from stretching and descending and kept the vocal cords, which sit on top of the larynx, from stretching. Interestingly, it was during the Enlightenment that the vocal cords were first named, and their role in the production of vocal sound was discovered. The lack of testosterone meant that the vocal cords remained approximately $7-8 \mathrm{~mm}$ in length, while adult, post-pubescent men have vocal cords ranging from 12-16 mm. Castrati vocal cords were likely shorter than those of the average operatic soprano as well, as the average length of mature women's vocal cords range from 8-12 $\mathrm{mm}$. This physiological difference may well explain why contemporary audiences described the castrato voice as sweeter than those of their female counterparts. ${ }^{150}$ Powerful lungs, large resonant rib cages, and short, agile vocal instruments — combined with natural talent and years of intense study — all played important roles in creating the signature sound of the castrati. ${ }^{151}$

In Ancillon's world, the castrato was the main category of eunuch. Turkish harem attendants and Chinese bureaucrats aside, most European men and women only

\footnotetext{
${ }^{148}$ Feldman, The Castrato, 10-11.

${ }^{149}$ Feldman, The Castrato, 10.

${ }^{150}$ Peschel and Peschel, 579-80. The distinction goes to Antoine Ferrin, who in 1744 was the first to demonstrate that singing was the byproduct of air vibrating along the cordes vocales, as he named them. ${ }^{151}$ Feldman, The Castrato, 10.
} 
experienced the castrated body through their experiences with the opera stars. In the seventeenth- and eighteenth centuries, the creation of these singing wonders (or monsters, depending on the opinion of the writer) was centered in Italy and drew much disgust from theologians, moralists, and philosophers. It does not appear to be a point of pride for the Italians either, as Burney's search for the castrati-making epicenter shows:

I enquired throughout Italy at what place boys were chiefly qualified for singing by castration, but could get no certain intelligence. I was told at Milan that it was Venice; at Venice that it was Bologna; but at Bologna the fact was denied, and I was referred to Florence; from Florence to Rome, and from Rome I was sent to Naples. ${ }^{152}$

Given the literal run-around by his Italian friends and hosts, Burney suggests that, despite the pride they feel for their opera, the method by which their male sopranos had achieved fame was not a topic of polite conversation. On this point, he states that "the operation is most certainly against the law in all these places, as well as against nature; and all the Italians are so much ashamed of it, that in every province they transfer it to some other." 153

Nevertheless, Burney finds one Italian doctor who tells him that the music conservatories themselves are not to blame for the actual castration of Italy's youth. Instead, the physician tells him, they are brought from the countryside in Puglia, auditioned at the schools, and, if their voices are acceptable, they are taken home to be castrated. Often, Burney suggests, the parents justify the castration by claiming medical necessity—after all, castration was otherwise a crime punishable by death or excommunication in Italy—which was a common treatment for several urogenital

\footnotetext{
152 Burney, 312.

${ }^{153}$ Burney, 312.
} 
problems before the advent of modern medicine. ${ }^{154}$ Others claimed that the castration was medically necessary after the boy had suffered an accident, the most common story that he had suffered from the bite of a wild animal like a boar. This trope became so well known (and in many cases was so patently false and ridiculous) that it found its way into the satirical novels and plays of the eighteenth century. ${ }^{155}$

Ancillon mentions this as well in the first part of his treatise, stating that:

Sometimes Necessity obliged People to undergo this Operation, as in the Case of some Distemper, otherwise incurable ... and they who are the unhappy Subjects of this Affliction ought not to be looked upon with an evil eye, but rather should merit our Compassion and Consolation. ${ }^{156}$

These men, unlike those who chose castration for the sake of money or fame, had no other option than to trade their fertility for their life. Supporting Burney's point—and unfortunately, quite possibly a case of false claims to medical necessity—Ancillon relates the story of Pasqualini. A well-known castrato in Rome at the turn of the eighteenth century, Pasqualini was born into a wealthy family and was castrated in his youth on account of an unnamed distemper. ${ }^{157}$ Statistically speaking, there is little likelihood that a regular boy, castrated to save his life, would have such a voice that he might become a Europe-wide star. Nevertheless, due to his respect for the singer, Ancillon does not intimate that his operation was anything other than a sad twist of fate for a youth of quality, though both he and Burney state that, in more general terms, castrated boys who

\footnotetext{
${ }^{154}$ Burney, 313.

155 John Rosselli, "The Castrati as a Professional Group and a Social Phenomenon, 1550-1850," Acta Musicologica 60, fasc. 2 (May-August 1988): 155.

${ }^{156}$ Ancillon, 45-46.

${ }^{157}$ Ancillon, 40.
} 
became famous singers often made up medical problems after the fact to save themselves and their families from excommunication.

Instead, it was the poor Italian peasants whom Ancillon and Burney see as the villains in this story. Despite their apparent love of opera and their respect and admiration for individual castrati, most authors sneered at the humble birth of these celebrities, who, with the stroke of a blade, went from rags to riches like the hero of a perverted children's story. One of Ancillon's favorites, Pauluccio, is presented as the victim of his family's avarice, specifically that of his castrato uncle, who was losing his voice and would soon lose his income. According to Ancillon, the uncle drugged a young Pauluccio with opium and performed (or had performed, Ancillon is not clear on this point) the operation on his talented young nephew. Concluding this story, Ancillon states "so fatal is it in Italy be the Son of a poor Man, and have a fine Voice, and I have often heard [Pauluccio] bemoan his Misfortunes in the most moving manner." 158 There is no quantifiable data to suggest whether or not this was a common story, but it was certainly part of the romanticized vision of the castrati in the eighteenth century.

Music historians have found evidence that many of the young boys may not have been totally coerced into castration. Notarial contracts from the seventeenth and eighteenth centuries show that some of these boys, young though they were, had a say in drafting the documents binding them to their vocal coach. Often, very young boys were contractually obligated to train with a coach and, if they showed enough promise, would

${ }^{158}$ Ancillon, 40. 
be castrated before they hit puberty. ${ }^{159}$ This certainly shows more restraint and care in the treatment of would-be castrati than the works of Ancillon and Burney suggest.

In some cases the contracts stated that the singing teacher would pay for the operation with the understanding that he would be paid a percentage of the castrato's profit once he became a professional musician. ${ }^{160}$ These documents are, in effect, apprenticeship contracts like those one might find in any other skilled craft; boys were clothed, fed, housed, and trained either in institutions or private houses. The line between private training and the conservatories was often non-existent, as private teachers were often maestros at the conservatories. ${ }^{161}$

Having finished their apprenticeships, castrati had options for pursuing their craft. Some stayed in Italy and joined religious choirs while others joined touring companies. As with other operatic performers, some castrati had close relationships with composers, who would write pieces highlighting a castrato's best vocal attributes. The professional relationship between Handel and Farinelli offers a well-known example of this phenomenon. Mozart, who studied singing under Manzuoli as a child visiting London, later wrote arias for the performer, though their relationship later soured as Mozart believed Manzuoli was asking too high a price for his role. ${ }^{162}$ Over the course of his career, the famed composer wrote seven operas featuring castrati, all of whom he met with personally before writing their arias, as was his custom with all performers in primary roles. ${ }^{163}$ Despite these relationships, or perhaps because of them, Mozart had

\footnotetext{
159 Rosselli, "The Castrati as a Professional Group," 152.

${ }^{160}$ Rosselli, "The Castrati as a Professional Group," 152.

${ }^{161}$ Rosselli, "The Castrati as a Professional Group," 159.

162 John S. Jenkins, "Mozart and the Castrati," The Musical Times 151, no. 1913 (Winter 2010): 58.

163 Jenkins, 60.
} 
both an admiration for their talent and a distaste for their personalities, offering unflattering opinions in his personal correspondence to friends and family. In this latter respect, Mozart was on par with many of his contemporaries, who often complained of the singers' arrogance, underwhelming dramatic skills, and exorbitant fees. ${ }^{164}$

Over the decades castrati as a group had gained the reputation of being difficult to work with, but a lucky few eventually attached themselves to noble or royal retinues, traveling and performing privately as their employer wished. In fact, many of the betterknown castrati of the eighteenth century ended their careers in private service: Farinelli with Charles IV of Spain, Atto Melani with the Medicis, and Siface with the D'Estes of Modena. ${ }^{165}$ However, this type of patronage became less common as the eighteenth century progressed; in the late seventeenth century a court castrato might be traded as part of foreign policy deals, as when Mazarin pressured the French royals to recruit castrati from their Italian family, including the Medicis and the Duke of Modena. ${ }^{166}$ By the mid-eighteenth century, the spread of public theaters increased the visibility and popularity of the castrati. This in turn was part of a broader trend separating opera from its previous home within the court and furthering the professionalization of musicians. ${ }^{167}$ Where once the castrati were at the mercy of a select group of nobles for their livelihood,

\footnotetext{
164 Jenkins, 68; 56.

165 Feldman, The Castrato, 61.

166 John Rosselli, "From Princely Service to the Open Market: Singers of Italian Opera and their Patrons, 1600-1850," Cambridge Opera Journal 1, no. 1 (March 1989): 8. In fact, there is overwhelming evidence that Melani was a spy. For more on Melani's eventful life, see Roger Freitas, Portrait of a Castrato:

Politics, Patronage, and Music in the Life of Atto Melani, New Perspectives in Music History and Criticism (Cambridge: Cambridge University Press, 2009).

${ }^{167}$ Rosselli, "From Princely Service," 18.
} 
by 1750 they were a part of the musical marketplace where good management, prudent financial decisions, hard work, and a bit of luck could make or break a career. ${ }^{168}$

As they aged and the lack of testosterone began to affect the strength and quality of the voice, many castrati became music tutors, training the next generation of singers and thereby ensuring the continuation of their taxonomized, 'monstrous' species. ${ }^{169}$ Others entered the priesthood upon their retirement. ${ }^{170}$ The wealthier castrati returned to the Italian peninsula (Farinelli, Senesino) or remained abroad (Rauzzini) to enjoy their golden years in lavish villas. ${ }^{171}$ Childless in the biological sense, castrati often became patrons in their own right, legally adopting nieces, nephews, and even other castrati to fill their splendid, empty homes with music. ${ }^{172}$

It is an age-old truism that many people born with a lack in one area develop super-human abilities in another: the non-sighted have acute hearing and show more sensitivity to vibration; loss of certain limbs leads to the development superior strength and dexterity in those remaining. But, aside from the castrati, it would be difficult to find a group of people who deliberately sacrificed normal bodily function to enhance a latent talent. For those categorized as monstrous, in most cases, the deformity was the talent, the reason why high and low alike flocked to freak shows and purchased pamphlets or engravings detailing the sometimes shocking physical differences on display.

\footnotetext{
168 Rosselli, "From Princely Service," 22.

${ }^{169}$ Feldman, The Castrato, 59.

${ }^{170}$ Feldman, The Castrato, 62.

${ }^{171}$ Feldman, The Castrato, 171-72.

${ }^{172}$ Feldman, The Castrato, 72-73.
} 
While they were described by the freakishness of their figures and the otherworldly powers of their vocal instrument, these men did not fit easily within the standard categories of dis/other-abledness in the eighteenth century. They were not born 'different,' unless we suggest that exceptional natural talent is a deformity. The castrato's post-birth de-formation was deliberate, unlike the misfortune of those blessés who were disfigured in accidents or through necessary surgery, though as we have seen, stories like these were occasionally used in a castrato's creation myth as well.

If, as Daston and Park suggest, wonder and marvel had become the purview of the masses by the Enlightenment, does it go too far to see the popularity of the castrati, dressed in elaborate costumes on richly decorated stages, displaying the byproducts of their medical condition, as nothing more than an upper-class raree show? Or were they merely polished shells, whose strange beauty was meant only to delight the senses of those less scientifically inclined? Such a characterization would do great injustice to the castrati-as-species and is dismissive of the decades of hard work and devotion to their craft. The admixture of titillation and pity many felt in their presence was the byproduct of their man-made condition, but so were the awe and wonder so many expressed upon hearing them sing. The cut of the knife made them eunuchs, but talent and dedication made them castrati. 


\section{Chapter Three}

Music and Sensibilité in the Enlightenment: The Sciences de l'homme go to the Opera

In the eighteenth century, the opera houses of Europe served as microcosms, reflecting and magnifying social mores and hierarchies. ${ }^{173}$ Each performance site was its own unique entity, a complex organism consisting of audience, performer, house, and stage that adapted, engaged, and responded to the broader culture outside its walls. ${ }^{174}$ The works themselves were polysemous, morphing as they moved across Europe. Foreign operas were often adapted to fit the local tastes, adhering to a given country's politics and cultural norms. ${ }^{175}$ Changes were also made to suit the talent, or lack thereof, of the performers themselves_ _ arias padded for a demanding prima donna, or perhaps cut entirely if a particular performer became ill or offended a member of the elite. Whole scenes might be cut or adapted based on the availability of mechanical scenery contraptions or the local popularity of ballet. Even performed exactly as written, opera was (and still is) processed and understood based on complex cultural context. As with Heraclitus's stream, one can never attend the same opera twice.

Most scholars who study opera and culture have focused on the relationship between opera and politics, nationalism, or aesthetic or cultural trends, but there is more to the story of opera in the Enlightenment. ${ }^{176}$ Some of the most exciting scientific

\footnotetext{
${ }^{173}$ Martha Feldman, Opera and Sovereignty, 8.

${ }^{174}$ Downing A. Thomas, Aesthetics of Opera in the Ancien Regime, 1647-1785, Cambridge Studies in Opera. (Cambridge: Cambridge University Press, 2002), 4.

${ }^{175}$ Charles Dill, introduction to Opera Remade, 1700-1750, ed. Charles Dill, The Ashgate Library of Essays in Opera Studies (Burlington, VT: Ashgate Publishing Company, 2010), xi.

176 Thomas, introduction to Aesthetics of Opera, 4. See Feldman (above) and R. J.Arnold for opera and politics in the eighteenth century. R. J. Arnold, Musical Debate and Political Culture in France, 17001830, Music in Society and Culture (Woodbridge: Boydell Press, 2017). Feldman's work also covers Italian
} 
advancements in the eighteenth century, including the budding fields of protoanthropology and physiology, were also integral to the way in which eighteenth-century Europeans understood opera. What it meant to feel, both the flood of emotion in the soul and its physical manifestation in the body, were hotly debated within the philosophical and scientific community - and what was an opera house if not a manufactory of feeling? At the heart of these questions about emotion and sensation lay an even bigger one: what does it mean to be human? Is sensibility a marker of the human? Does nature or artifice bring us closer to the true expression of humanity? How do the voices of the castrati, powerful and otherworldly, fit into these debates on music and sensibility?

Before we delve into the philosophical questions, a few simple ones must be addressed: what was opera in the eighteenth century? Who was writing it? Performing it? Who was listening, and what did they hear? Let's set the stage, so to speak, with a brief history of opera in the Ancien Régime.

\section{C'est Merveilleux: Opera in the Ancien Régime}

In the modern world, going to the opera is usually a fairly somber affair. We pull uncomfortable dresswear from the back of our closets and proceed with a patrician stateliness to our seats. The polite buzz ceases as soon as the first notes of the overture

nationalism; see also The Work of Opera edited by Richard Dellamora and Daniel Fischlin for a broader range of articles on the topic. Richard Dellamora and Daniel Fischlin, eds., The Work of Opera: Genre, Nationhood, and Sexual Difference (New York: Columbia University Press, 1997). See Thomas (above) and Cynthia Verba's work for eighteenth-century France, especially Cynthia Verba, Music and the French Enlightenment: Rameau and the Philosophes in Dialogue, 2nd ed. (Oxford: Oxford University Press, 2017). 
are played, and the audience stays silent until it's time to clap. We might hear-or make ourselves - the occasional sniff at a moment of tragedy or a polite laugh during a particularly funny moment, or, more common than both, beleaguered sighs of boredom at all of the shrieking in unknown languages. It is rare, and would be quite shocking, to hear a full-throated laugh, unrestrained weeping, or loud 'boos!' during a night out at the opera. Certainly never derisive flatulence from the balcony or orgasmic moans from the dark recesses of the private boxes.

And yet, for most of the eighteenth century, everyday human noises were far more common than silence, even at the most prestigious European opera houses. This trend towards listening to and truly experiencing an operatic performance, as opposed to merely attending one, began in the mid eighteenth century and coincided with changes in the social norms surrounding public performances and in the performance spaces themselves.

In Enlightenment Paris, opera and The Opera were not the same thing. The Opéra — as the Académie Royale de Musique was known—was not particularly public in the strictest sense. Anyone could attend the Opéra-Comique or the vaudevilles, but only those with the best blood, highest pedigree, or the most money could hold a first-level box at the Opéra. Founded by Louis XIV in 1669, the Opéra was a state-funded entity that churned out musical propaganda celebrating the virility, intelligence, and benevolence of the king. References and representations of Louis XIV appeared implicitly, especially within the new musical genre of tragédies en musique, where the Sun King was seen as one of the mythical and historical heroes whose stories had been 
put to music. ${ }^{177}$ Similar to the court-sanctioned allegorical paintings portraying Louis XIV as Apollo or Hercules, French opera was full of the same rigid rules of presentation, symbology, and grandeur as the performative absolutism of the last decade of his reign. ${ }^{178}$ In this environment, even operas that were not about the king were about the king.

Throughout the seventeenth century and well into the eighteenth, French opera was suffused with spectacle, like the monarchy itself. While many dramatists (including Racine) argued against the overuse of such plot devices in theater they were encouraged in opera, where gods, goddesses, demons, and other unworldly characters alike all graced the stage. They often performed marvelous feats with the help of elaborate machines, earning France the epithet "the home of the machine opera." The most extravagant were the tragédies en musique, also known as tragédies lyriques — musical tragedies primarily taken from Greek and Roman mythology. ${ }^{179}$ Like the raree shows, then, opera indulged the French public's taste for the marvelous.

As for the Opéra itself, contemporaries agreed that it was the height of grand spectacle, covered in gilt, satin, and more baroque curlicues than the Sun King's favorite wig. Originally designed for Molière's use, the king's superintendent of music Jean Baptiste Lully—master baroque composer and lightning rod in later debates on French musical style — convinced the monarch to give it to him instead. And so, from 1673 until

\footnotetext{
177 Thomas, Aesthetics of Opera, 53.

${ }^{178}$ Thomas, Aesthetics of Opera, 65; 97. For a broader look at Louis XIV's spectacular propaganda, see Georgia Cowart, The Triumph of Pleasure: Louis XIV \& the Politics of Spectacle (Chicago: University of Chicago Press, 2008).

${ }^{179}$ Aubrey S. Garlington, Jr., “'Le Merveilleux' and Operatic Reform in 18th-Century French Opera,” The Musical Quarterly 49, no. 4 (October 1963): 485.
} 
a devastating fire gutted the hall in 1762, the Opéra's singers, musicians, and dancers performed at the king's pleasure three or four times a week, eleven months out of the year. $^{180}$

The king and queen had their own boxes, his on the right when facing the stage, hers on the left; this placement played an important role in the delightfully punny coin $d u$ Roi (king's corner) and coin de la Reine (queen's corner) in the operatic Querelle des Bouffons, which pitted the king's pro-French followers against the queen's pro-Italian ones. All of the boxes faced each other instead of the stage, making it easier to pay attention to the important action: the audience. ${ }^{181}$ Members of the extended royal family had boxes based on their degree of royalty, including boxes literally placed upon the stage, sharing the same spotlight as the singers. Larger boxes sat up to a dozen people and often served in the earlier years as miniature salons, where the latest news, fashions, and gossip were shared freely and loudly during performances. ${ }^{182}$ The rest of the nobility often spilt the cost of their boxes and alternated performances; being seen at the Opéra half-time was far better than not being seen at all. ${ }^{183}$

Higher up, in the second and third tier, lesser nobles, priests, and the occasional courtesan had the chance to rent a seat for a single performance. Even worse were the parterre and the paradis of the upper balcony, a home-away-from home for soldiers, servants, dandies, dogs, and anyone willing and able to pay for the privilege to stand in

\footnotetext{
${ }^{180}$ James H. Johnson, Listening in Paris: A Cultural History, Studies on the History of Society and Culture; vol. 21, (Berkeley: University of California Press, 1995), 11.

${ }^{181}$ Johnson, Listening, 13.

182 Johnson, Listening, 16.

${ }^{183}$ Johnson, Listening, 13.
} 
the pungent semi-darkness to catch a glimpse of the royal court. ${ }^{184}$ Not all witnesses to the king's grandeur had to pay for the privilege, though; by 1750 hundreds of subjects were granted access to the parterre and the amphitheater for free, thanks to their positions as well-known artists, writers, scientists, or officers in the king's service. The Opéra made less money, of course, but for a regime built on personifying power and benevolence, these symbolic acts more than made up for the loss of revenue. ${ }^{185}$

Aside from the Opéra there were few public places where the better-heeled could be seen attending musical performances. Beginning in 1725 , the king permitted concerts at the Tuileries' Salle des Suisses on holy days when the Opéra was closed. After two years, the events had proved so popular that their creator Anne-Danican Philidor was granted permission to give concerts twice a week in summer and once in winter. ${ }^{186}$ These performances were often a mish-mash of scenes from the Opéra alongside instrumental chamber music and vocal works like motets and oratorios, the latter no doubt integral in earning these performances the appellation Concerts Spirituels. ${ }^{187}$ The concert spirituel was composed of singers and musicians from the Opéra; the audience was the same, too, and if contemporary reports can be believed there was hardly more piety to be had at the Tuileries than at the Opéra. ${ }^{188}$

\footnotetext{
${ }^{184}$ More foul-smelling even than the sweat-stench of the standing-room-only parterre, the paradis surrounded the Opéra's toilets. Johnson, Listening, 17-18. This section was most certainly called a "paradise" ironically due to its proximity to the bathrooms.

185 Johnson, Listening, 19.

${ }^{186}$ Johnson, Listening, 71.

${ }^{187}$ William Weber, "Learned and General Musical Taste in Eighteenth-Century France," Past \& Present 89 (November 1980): 69.

${ }^{188}$ Johnson, Listening, 72-73.
} 
The opera audience was never monolithic. Whatever the objective for attending a public performance — to see and imitate the nobility, to be seen and admired, to make social and political connections, or more likely a combination of motives - everyone experienced something whether they were paying strict attention or not. What they felt, and how they understood their reaction to the lyrics and music, was influenced by contemporary concepts of le bon goût - the good taste that helps one distinguish between a good piece of art or literature and a bad one.

While historians no longer demarcate 'high' and 'low' culture as cleanly as they did in the mid-twentieth century, earlier scholarship on taste and aesthetics can still shed light on who decided what was tasteful, and who followed. The audience of the Opéra may have contained a cross-section of Parisian society, but only a few opinions mattered. Exactly whose opinion mattered, whose taste should be emulated, and whose knowledge could be trusted was often in flux. Royal favorites and salon darlings went in and out of fashion, and musical patrons (with the exception of the king himself) came and went based upon the state of their reputation or fortune.

The notion of musical authority likewise was heavily debated in the mideighteenth century, with the Mercure de France offering up both the opinions of les savants and les connoisseurs, as well as le public in its monthly summaries of performances. ${ }^{189}$ The former category comprised mostly of musicians and composers themselves, industry-specific knowledge and technical skill. On the other hand, connoisseurs did not necessarily have formal training in either music or aesthetic

${ }^{189}$ Weber, "Taste," 65. 
criticism but rather owed their prestige to their place within the hierarchy of musical knowledge, where they acted as the cultural bridge between professional composers and musicians on the one hand and the public on the other. ${ }^{190}$ Both savant and connoisseur were used derogatively as well, especially when their opinion went against those of the majority-public. ${ }^{191}$

There was no strong Classical tradition of music criticism from which music enthusiasts could learn their craft, in stark contrast with the long history of theater, sculpture, and painting in the West. Excepting a few fragments, there were no examples of Greek and Roman musical composition at all; any account or history of ancient music performance was purely second-hand, often filtered through the perspective of the renaissance humanists. Unlike the great chain of artistic works in imitatio available to playwrights or visual artists and their respective critics, composers, connoisseurs and savants had little to draw from outside of the mathematically-driven music theory of the medieval quadrivium. And so, more than with other forms of artistic expression of the day, the admirer-critics of eighteenth-century Europe had to rely more exclusively on feeling, refined by le bon goût. ${ }^{192}$

For writers on aesthetics such as Lecerf de la Viéville, the public, which he often referred to as le peuple, was not the general public of fishmongers and ribbon sellers but the honnêtes gens, the gens du monde, who could afford to attend the theater but were not necessarily part of the noble classes. ${ }^{193}$ Because the tradition and hierarchy of (non-

\footnotetext{
${ }^{190}$ Weber, "Taste," 66, 68; Jolanta T. Pekacz, "The Salonnières and the Philosophes in Old Regime France: The Authority of Aesthetic Judgement," Journal of the History of Ideas 60, no. 2 (April 1999): 285.

${ }^{191}$ Weber, "Taste," 65.

192 Weber, "Taste," 60-61; 68.

${ }^{193}$ Weber, "Taste," 67.
} 
technical) musical knowledge was so ill-defined, the opera-going public were free to discuss and argue over the merits of a certain score or singer and have their opinion received based on their inherent taste level, itself a proxy of their social standing.

When it came to aesthetic judgement, seventeenth- and early eighteenth-century writers divided those who had natural taste and those who were forced to acquire it through study along strict lines. Lecerf de la Viéville and Montesquieu among others saw the honnêtes gens, who lacked formal, professional training in art or music as better judges of artistic merit. Conversely, they believed savants based their aesthetic judgments on book-learning and rationality rather than inherent qualities refined by the rules of polite discourse. That said, both of these men acknowledged that professional or learned opinions were a necessary part of aesthetic discourse, provided they were properly tempered by—and referential to— the refined sentiments of honnêteté. ${ }^{194}$

Men of letters generally agreed that the most natural, delicate tastes belonged to upper class women. Unsullied by the intellectual intensity of formal academic trainingthough usually trained in music, a connoisseurship later ignored by the philosophesthese women presided over salons, enforcing the laws of polite discourse and passing judgments on matters of taste. The prevailing belief was that art should be judged intuitively, though as the century progressed intuition and emotion fell under the purview of anatomists and systemetizers. In the early decades of the century, though, women's intuition was an arbiter of taste: stronger than that of men, women's opinions were at the very least respected outwardly by their salon protégées. For a time, then, their naturally

${ }^{194}$ Pekacz, "The Salonnières," 284; 280; 282. 
superior perception of aesthetics gave salonnières equal footing within this carefully proscribed sphere. ${ }^{195}$

For connoisseurs and savants during this period, there was necessarily a fine line between dictating taste and leading others to properly appreciate music. As men of letters, they wrote extensively on aesthetics, philosophy, or the sciences as well as publishing summaries of the newest libretti or guides to this season's new productions. The connoisseurs' opinions were often in-step with those of the general opera-going public, though many_-including those identified as philosophes who took part in the various querelles - derided the spectacles and forms in favor of new, often foreign compositional styles. ${ }^{196}$

By the mid-century, however, the new generation of intellectuals, the philosopheencyclopedists, undertook to upend the traditional notions of polite discourse and aesthetic authority that had reigned for the last hundred years. Where salonnières had been regarded as guardians of taste and inherent good judgment on matters of aesthetics and sentiment, many philosophes painted them as petty and insipid. Diderot places this opinion in the mouth of Rameau's Nephew:

Opposite [the master of the house] there is a straightlaced female trying to look important ... Item, she is more spiteful, proud and stupid than a goose. Item, she thinks she is witty. Item, you have to persuade her that you think she is more so than anybody else. Item, the woman knows nothing and yet makes decisions. Item, her decisions have to be applauded with hands and feet, one must jump for joy, swoon with admiration: 'How beautiful! How delicate! Well put, acutely observed, uniquely felt! Where do you women get all this from? Without any studying, by the sheer power instinct, by natural reason alone; it really is

\footnotetext{
195 Pekacz, "The Salonnières," 296.

196 Weber, "Taste," 81-83.
} 
miraculous. And then people say that experience, study, reflection, education all have their part to play.' And other stupidities of the same sort. ${ }^{197}$

For figures like the Nephew, these women's power came from their relationship to their husband, the one who doled out funds, food, clothing, and a semblance of prestige. Such a woman must be flattered in order to keep one's place within the household. What was once a fruitful back-and-forth between salonnières and their protégées had become a master class in flattery. Not only did these women lack the formal education needed to pass judgment, they were too stupid, or too vain, to know then they were being mocked.

We know that Diderot and some of his compatriots still frequented the salons of women such as Madame du Deffand and later Mademoiselle de L'Espinasse. And, while as a group they may have respected the salonnières' opinions on some few matters, Diderot's fictional sketch of L'Espinasse in D'Alembert's Dream portrays her as snide, slow and more unpleasant than contemporary accounts of her character suggest. Lacking noble lineage or financial security, L'Espinasse built her salon through sheer intelligence and strength of will — facts that Diderot would have done well to remember. ${ }^{198}$ While not all salonnières matched L'Espinasse in terms of her charm and innate intelligence, she was certainly not the only woman of sense in eighteenth-century Europe.

Beyond even their low opinion of women, some philosophes rejected the entire enterprise of polite discourse as it existed in the middle of the eighteenth century. One of

\footnotetext{
${ }^{197}$ Denis Diderot, Rameau's Nephew and D'Alembert's Dream, trans. with introductions by Leonard Tancock (New York: Penguin Books, 1966), 72. We meet Uncle Rameau — the celebrated composer and music theorist Jean-Phillipe Rameau-later in this chapter.

${ }^{198}$ Leonard Tancock, introduction to D'Alembert's Dream in Rameau's Nephew and D'Alembert's Dream by Denis Diderot (New York: Penguin Books, 1966), 140.
} 
the more combative members of D'Holbach's circle, ${ }^{199}$ the soldier-poet encyclopedist

Jean-François de Saint-Lambert ${ }^{200}$ had this to say on the entire concept of salon

honnêteté:

One gives the name of honnête to manners, to the attentions of a polite man, the esteem which these small virtues deserve is so little, in comparison with those which an honest man deserves, that it seems that these abuses of a word that expresses such a respectable idea, prove the progress of corruption. Happy is he who knew how to distinguish the true honest man from that frivolous and artificial honnete, happy is he who carries to the depths of his heart the love of the honest man, and who, in the transports of this amiable and tender passion, exclaims sometimes with Guarini: ${ }^{201} \mathrm{O}$ holiest honorable man, you alone are the well-born soul of an inviolable god. ${ }^{202}$

Again it is the honest man, not the polite, fawning one, who alone is worthy of esteem.

In the seventeenth- and eighteenth centuries, defining and debating taste appears

to be nearly as popular a pastime among the opera-going public as experiencing a play, concert, or opera itself. As we have seen, one's taste level was primarily defined by one's social standing. Title and fortune were obviously important factors, but being a member

\footnotetext{
${ }^{199}$ Paul-Henri Thiry, Baron d'Holbach, hosted one of the most intellectual productive — and most infamous - French salons in the eighteenth century. A firm atheist and proponent of atheistic materialism, d'Holbach anonymously published several anti-religious, pro-materialist, treatises during his lifetime, through he was known in intellectual circles to be the author of many of them. Members of his circle included Diderot, d'Alembert, Rousseau, Melchior von Grimm, Claude-Adrien Helvétius, and Étienne Bonnot de Condillac, all well-known and prolific philosophes themselves. While few members of the circles were (or at least admitted to be) staunch atheists themselves, d'Holbach's salon was known as a safe space to discuss topics that were frowned upon at some of the more genteel salons. Many regulars at d'Holbach's salon, including d'Holbach himself, contributed to the Encyclopédie. See Alan Charles Kors, D'Holbach's Coterie: An Enlightenment in Paris (Princeton: Princeton University Press), 1976. Kors offers a thorough, fascinating account of d'Holbachs salon.

${ }^{200}$ Kafker and Kafker, 347-48. This is the same Saint-Lambert who fathered the well-respected mathematician and natural philosopher Gabrielle Émilie Le Tonnelier de Breteuil, Marquise du Châtelet's love child, a pregnancy which ultimately killed her.

${ }^{201}$ Likely Giovanni Battista Guarini, the seventeenth-century Italian poet.

202 "On donne le nom d'honnête aux manieres, aux attentions d'un homme poli, l'estime que méritent ces petites vertus est si peu de chose, en comparaison de celles que mérite un honnête homme, qu'il semble que ces abus d'un mot qui exprime une si respectable idée, prouvent les progrès de la corruption. Heureux qui sçait distinguer le véritable honnête de cet honnête factice $\&$ frivole, heureux qui porte au fond de son coeur l'amour de l'honnête, \& qui dans les transports de cette aimable $\&$ douce passion, s'écrie quelquefois avec le Guarini: $O$ sanctissima honestade, tu sola sei d'un alma ben nata l'inviolabil nume." Jean-François de Saint-Lambert, "Honnête," in The ARTFL Encyclopédie, vol. 8, p. 287.
} 
of an academy or a regular at an influential salon also played a part in deciding who had taste and who was merely a savant or connoisseur soi-disant. Where salonnières once held sway over aesthetic discourses as examples of natural feeling, men like Voltaire, D’Alembert, Diderot, and Rousseau attempted to fill the role themselves, citing their rational approach to feeling and sensation as better suited to such important judgments. ${ }^{203}$ By the time the final volume of the Encyclopédie was published, the philosophes had effectively relieved upper-class women of their traditional role as arbiters of taste. As France moved closer to Revolution, polite discourse disappeared from the salons of wellto-do-women and into the male-dominated clubs and academies, where politeness, and women, were merely an afterthought, if they were thought of at all. ${ }^{204}$

2. Exciting the Machine: Music as Medicine

We have already noted that taking supreme pleasure in the arts was considered a sign of heightened sensibility in the eighteenth century. That said, not all art forms were considered equal or socially coded as appropriate for 'masculine' men. Opera in general, and the castrati in particular, were certainly problematic for many moralists: the powerful voices of the castrati were too penetrating to the senses, unmanning the listener as he indulges in himself as the receptive audience member. ${ }^{205}$ The very notion of an art that stirs the passions was considered by many moralists and philosophers to effeminize men,

\footnotetext{
203 Pekacz, "The Salonnières," 288-90.

${ }^{204}$ Dena Goodman, The Republic of Letters: A Cultural History of the French Enlightenment (Ithaca: Cornell University Press, 1994), 303-04.

205 Thomas A. King, "The Castrato's Castration,” Studies in English Literature, 1500-1900 46, no. 3 (Summer 2006): 569.
} 
as a lack of emotional control was historically associated with women and the feminine. ${ }^{206}$ This codification of certain feelings and pleasures as either masculine or feminine, good or bad, was an integral part of the eighteenth-century debate on sensibility.

While the French were generally distrustful of the castrati and no castrati graced the stage of the Opéra or Comédie-Française, the castrati were well-known throughout Europe. ${ }^{207}$ Any Frenchman with the means to travel abroad, especially to Italy, birthplace of castrati, or England, where they were (almost) universally adored, would have seen the castrati perform. The better-heeled may have even dined or danced with one of Europe's first superstars. They may have been disdained and even pitied in France, but they were not unknown to the musical theorists, composers, philosophes, or the populace at large.

To correct this oversight in the academic literature, we must situate the castrati within the broader French debate on sensibility and music. If opera was a touchstone for the new debates on the science of sensibility, its most famous performers must also be taken into account. The castrati held a central place in many debates about music, especially those concerned with the morality of opera and its didactic potential. In others, the castrati were merely ancillary figures, paraded onto the stage, so to speak, to illustrate a broader point, a deeper truth about the music-sensibilité connection.

In France, the issues surrounding music and sensibility debate hinged on a handful of interrelated questions: what musical form, melody or harmony most resonates

\footnotetext{
206 Julia Prest, "In Chapel, on Stage, and in the Bedroom: French Responses to the Italian Castrato," Seventeenth-Century French Studies 32, no. 2 (2010): 160.

207 There were, however, castrati in the King's chapelle du roi-the same castrati used in Nollet's electrical experiment in chapter one.
} 
both emotionally and physically within the human body? What brings about the most natural, authentic feeling and why? While opera was arguably the most popular form of music in seventeenth- and eighteenth-century Europe, music theory proper and treatises on the music-sensibilité relationship applied to all musical genres of the era. Opera, that alchemical concoction of music and words, song and harmony, ritual and spectacle, was the genre that truly captured the public's imagination. As such, opera took center stage in many debates on 'naturalness,' especially in France. Naturalness could refer to anything from the effectiveness of mimicry in the music itself to the purity of emotions elicited from the audience.

Two important works explore the relationship between music and sensation, Cynthia Verba's Music and the French Enlightenment: Rameau and the Philosophes in Dialogue and Downing A. Thomas' Aesthetics of Opera in the Ancien Régime, 16471785. The former, a newly expanded and revised version of her 1993 monograph, focuses on Rameau's decades-long dialogue with the philosophes, most notably Rousseau, on the primacy of melody versus harmony. Verba asserts that this series of arguments, which raged intensely from 1750 until Rameau's death in 1764, centered around Rameau's breakthroughs in music theory and the birth of the Encyclopédie, was integral to the development of both bodies of work. The range of topics touched upon in these dialogues, from the basic nature of scientific inquiry to the role of reason in art, both inspired and informed debates at the very heart of the Enlightenment in France. ${ }^{208}$

208 Verba, 2-7. 
Following the trajectory of Verba's exploration of music as both art and science, Thomas devotes the second half of Aesthetics of Opera to one of his two main theses: that by midcentury, opera had become a touchstone for discussions of sensibility within the broader society. Thomas cites the important medico-philosophical works on the mechanics of emotion, especially those on music and sensibility, yet his connection to the concepts of naturalness does not take into account the ways in which authors of the period, including Rousseau, used the most famous singers of the era, the castrati, as foils in their arguments on the primacy_or concerning lack thereof-of naturalness and mimicry of nature in the production of so-called proper feelings stirred by opera. In fact, there is only one reference to the castrati in the book, a quote from a pro-French querelle pamphleteer, who cited the "unnaturalness of the eunuchs" as a point against Italian opera. $^{209}$

It is impossible to understand the relationship between sensibility, nature, verisimilitude, and music in the mid-eighteenth century without briefly summarizing the Querelle des Bouffons. The Querelle des Bouffons was one in a series of musical querelles that started in 1702 with the writings of Le Cerf, and ended with the so-called Gluckiste-Piccinniste querelle in the 1770s. ${ }^{210}$ The Querelle des Bouffons pamphlet war was triggered by the 1752 arrival of the two-act Italian intermezzo entitled La Serva Padrona ("The maid mistress") at the Opéra. Formerly reserved for the propagandistic, spectacular king-as-hero operas of Lully and Rameau, La Serva Padrona brought Italian

\footnotetext{
209 Thomas, Aesthetics of Opera, 223.

${ }^{210}$ Arnold, 2. Like any large, complex, or lengthy cultural movement (e.g. Renaissance humanism, the Enlightenment) the borders here are fuzzy, and not all historians might agree with Arnold's timeframe or his inclusion of the Le Cerf debacle.
} 
comic directly to the French king's stage for the first time. ${ }^{211}$ The intermezzo had already performed across Europe, and its popularity on the French stage kept the Italian troupe in the country until 1754, coinciding with the publication of the first four volumes of the Encyclopédie. ${ }^{212}$ Over 60 pamphlets, totaling thousands of pages, were produced during the Querelle des Bouffons; more than simply a heated disagreement over musical forms, it was at its heart a philosophical and political debate with real-world implications. ${ }^{213}$

On the side of French opera, the coin $d u$ roi, were men who held royal appointments, belonged to the upper aristocracy, or were members of the French musical establishment who owed their livelihood to the king and benefitted from the continued lionization of French opera. Members of the aristocracy especially found the Italian opera, and pro-Italian supporters, to have less refined tastes due to the situation of their birth. ${ }^{214}$ Likewise, the salonnières favored French music as it, like their salons, was classic and orderly; the genteel rules of French opera were in place for a reason, mainly to preserve the honnêteté of the audience. ${ }^{215}$ The pro-French group also invoked contemporary ideas on the climate-race-temperament connection, stating that while

\footnotetext{
${ }^{211}$ Jomarie Alano, "The Triumph of the Bouffons: La Serva Padrona at the Paris Opera, 1752-1754," French Review: Journal of the American Association of Teachers of French 79, no. 1 (2005): 124. The Querelle des Bouffons is a popular subject among both cultural historians and historians of music. Several fairly recent takes not covered here include Geoffrey Higgins, "Old Sluts and Dangerous Minuets: Or, the Underlying Musical Tensions of the Querelle Des Bouffons," Eighteenth-Century Studies 45, no. 4 (2012) and Downing A Thomas, "Rameau's Platée returns: A case of double identity in the Querelle des bouffons," Cambridge Opera Journal 18, no. 1 (2006).

212 James Johnson, “The Encyclopedists and the Querelle Des Bouffons: Reason and the Enlightenment of Sentiment," Eighteenth-Century Life 10, no. 2 (1986): 23.

${ }^{213}$ Johnson, "The Encyclopedists," 13-14.

${ }^{214}$ Alano, 130.

${ }^{215}$ Jolanta T. Pekacz, "Gender as a Political Orientation: Parisian Salonnières and the 'Querelle de Bouffons," Canadian Journal of History 32, no. 3 (December 1997): 409.
} 
Italian music might suffice for the Italians, the French had inherently different musical tastes because they were different peoples with inherently different natures. ${ }^{216}$

On the coin de la reine were the majority of encyclopedists, who believed the purpose of music was to promote pleasant feelings, not promote the monarchy and its institutions. Writers such as Rousseau and Grimm urged le publique to contextualize the sensations they experienced using reason, making opera attendance both healthpromoting and edifying. ${ }^{217}$ In the traditional system, le bon goût was determined by the gentility that generally accompanies a noble birth. Flaunting such conventions, the proItalian pamphleteers asserted that subjective standards founded on what they perceived to be their own, more rational principles were the best way to judge music. ${ }^{218}$ While the creation of standards seems to fly in the face of their principles for natural, personal reflection, the encyclopedists — especially Rousseau — sought to base their system of aesthetic judgment on a work's verisimilitude, its ability to both communicate, and provoke, true emotion. ${ }^{219}$ For the pro-Italian men of letters, French spectacles dazzled the eyes, but they did not touch the heart.

The Querelle des Bouffons represents many things to many people, both those who participated and the scholars who have come after them. Among its many roles, the Querelle des Bouffons can be seen as a culmination, a crystallization of the complex relationship between national sensibility and the way in which language reflected such feeling and who brought forth the best, purest, and most natural emotion through their

\footnotetext{
216 Johnson, “The Encyclopedists," 19.

217 Alano, 131-32.

218 Johnson, "The Encyclopedists," 16.

219 Johnson, "The Encyclopedists," 17.
} 
opera. The debate used the fight between the coin du roi and the coin de la reine, between French and Italian opera, respectively, to frame broader questions on music and sensibility, and the merits of verisimilitude, closeness to nature on the opera stage. Even more broadly, the debate asked who had the right to dictate taste, and what makes one person's aesthetic judgment more legitimate than another's. ${ }^{220}$

Much of the older work on the Querelle des Bouffons has viewed it as a relatively standalone moment, one that intimately captured an intellectually and politically vigorous moment in time. More recently, some scholars such are R. J. Arnold have contextualized it within a near century-long span of querelles on music that continuously set and re-set the aesthetic status quo. It's been viewed as a proxy for forbidden—or at least unwiseairing of political frustrations, as an expression of nationalism, and as a symptom of the broader trend of delegitimization of the salonnières and, more broadly, of women's status as true tastemakers outside of the intimate family setting. ${ }^{221}$

The large corpus of primary documents, most in the form of pamphlets, reveals that the Querelle des Bouffons had the power to be all of these things and more. The querelle was a polysemous debate about music, certainly, but also the wider site of the cultural anxieties of the day. That said, few scholars have situated this episode, so tightly tied to the best and most pristine expression of sensibilité, to the scientific debate surrounding the physicality of feeling, both physical manifestations of emotion in the

\footnotetext{
${ }^{220}$ Johnson, "The Encyclopedists," 15.

${ }^{221}$ Charles B. Paul, "Music and Ideology: Rameau, Rousseau, and 1789," Journal of the History of Ideas 32 , no. 3 (July-September 1971). Paul gives us a nice historiography on the line many have drawn from the ideologically motivated "anti-establishment" philosophes in the coin de la Reine to the outbreak of the French Revolution thirty years later. See Pekacz's articles "Gender" and "The Salonnières," both discussed in this chapter.
} 
body and the physiological reaction to sound until very recently. Like the body and work of the castrati, the Querelle des Bouffons should also be viewed as an integral part of the all-encompassing, Enlightenment-era desire to reckon the mysterious connection between body, sensation, and emotion, and grapple with the implications of those connections and what they uncover about human nature.

Between the philosophes and encyclopedists on the one hand and the generally more conservative moralists, philosophers, composers, and music theorists, hundreds of pamphlets, letters, and treatises were written about music in eighteenth-century France. As such, only a few integral texts are examined here, those which best illustrate the arguments of our key actors, including Rousseau, Diderot, and Grimm in the former group and Pierre Estève along with preeminent composer and music theorist JeanPhillipe Rameau in the latter. Thomas has noted that these eighteenth-century texts differed greatly in approach to their Renaissance and seventeenth-century intellectual ancestors. While these earlier writers focused on the theological and cosmographical ramifications of 'musical magic,' eighteenth-century writers described the effects of music from physiological-mechanical and moral points of view. ${ }^{222}$ Natural philosophers had long observed the effect of musical vibrations on water and glass - the well-known 'soprano breaks a wine glass' trick that is still an image in our popular culture todayand in the eighteenth century, curious minds armed with new theories on nerves sought to extend the effects of music's power to the human body. ${ }^{223}$

222 Thomas, Aesthetics of Opera, 186-87.

${ }^{223}$ Thomas, Aesthetics of Opera, 188. 
As Verba notes, the neoclassical dictum that the best art was an imitation of nature, a concept the Ancient Greeks called mimesis, saw a resurgence during the middle decades of the eighteenth century. This aesthetic philosophy did not exist in a vacuum, but co-existed with various moral and metaphysical philosophies as well. Cartesian philosophy held sway over the French reception of the arts in the second half of the seventeenth century; even in Descartes' supremely rational universe, there was room for the passions, as he believed that emotion could transmit ideas and inspire the mind to engage on a deeper level. ${ }^{224}$ Such intellectualized portrayals of the passions continued into the eighteenth century, and one of its staunchest proponents was Rameau. This philosophical bent shows up in his treatise on aesthetics (Observations sur notre instinct pour la musique) as well as his music theory works. Music theory is at its heart the scientific arm of music, and Rameau and his Cartesian proclivities, the scientific laws governing harmony, made it the perfect vehicle for evoking certain passions with precision. $^{225}$

Alongside Rameau, Pierre Estève argued that French opera was simply more nuanced, inspiring the gentler, more naturally refined passions of the French gens $d u$ monde. Estève contrasted this explicitly with the "coarser" passions of the Italians, stating "those who, from too great a familiarity with Italian music, do not know how to distinguish the intermediate nuances of French music, accuse the latter of monotony."226 More importantly for this discussion, perhaps, are his thoughts on sensibility. Estève

\footnotetext{
${ }^{224}$ Verba, 36-37.

${ }^{225}$ Verba, 41.

${ }^{226}$ Blake Stevens, "Monologue Conflicts: The Terms of Operatic Criticism in Pierre Estève and JeanJacques Rousseau," Journal of Musicology 29, no. 1 (Winter 2012): 31. Quote translation by the author.
} 
linked opera to the physiology of sensibility, noting that operatic music "puts the soul in movement" by eliciting oft-complex combinations of emotions (e.g., terror or excitement). ${ }^{227}$

On the other side of the harmony-melody debate was Rousseau, an accomplished writer on music and a composer and talented transcriber in his own right. For Rousseau, sensibility was an end, not a means. He saw melody as a vehicle for immediate, purely emotive expression — a natural language of the passions — an idea he expanded upon in his works on the shared origins of melody and language. ${ }^{228}$ His original draft of this work, entitled Du principe de la mélodie ou réponse aux erreurs sur la musique, was written in 1755 during the height of these debates, but it went unpublished at the time. Sections of Du principe were published as a part of the larger Essai sur l'origine des langues in 1781, though the only detailed theory on melody published in his lifetime appeared in his Dictionnaire de musique in $1768 .{ }^{229}$ For Rousseau, harmony was mere artifice, an unnatural human creation ruled by reason, not instinctive expression-much like the bodies of the castrati he occasionally criticized in his work. Whatever pleasures may be derived from the contrivances of harmonies, they were caused by physical, medico-physiological mechanisms completely divorced from what Rousseau considered 'true' feeling. ${ }^{230}$ Again, like the sound of the castrati, these complex harmonies was too far removed from nature to elicit a genuine response from the audience.

\footnotetext{
227 Stevens, 32.

${ }^{228}$ Verba, 41.

${ }^{229}$ Verba, 43.

${ }^{230}$ Verba, 46.
} 
The Dictionnaire de musique was a culmination of years of Rousseau's thoughts on music, many of which he previously shared in Encyclopédie articles, though the former includes many subjects which expanded contemporary conceptions of musical terminology ${ }^{231} \mathrm{He}$ taxonomized his music-related terms thoroughly, often crossreferencing and sub-dividing them into stricter and stricter definitions. ${ }^{232}$ Many of these dictionary entries offered both a traditional definition as well as a dose of Rousseau's distinctive philosophical polemics as well as his anti-French, pro-Italian stance on contemporary opera. ${ }^{233}$

In his Dictionnaire entry entitled “Music," Rousseau summarizes his general taxonomy of music and the way in which different types affect the listener:

One might and perhaps should further divide Music into natural and imitative. The first, limited to the physics of Sounds alone and acting only on the sense, does not at all convey its impressions to the heart, and can produce only more or less pleasant sensations ... The second ... expresses every passion, paints every portrait, renders every object, submits all Nature to its learned imitations, and thus conveys to the heart of man the feelings appropriate for affecting it. ${ }^{234}$

Here, we see the limit of Rousseau's taste for the natural: while it is elevated above that which is far removed from nature, 'natural' music such as simple chansons or hymns only affected the body in the grossest way. To truly entice the passions or positively affect the listener's sensibility, man must give subtle, well-placed aid to nature:

It is only in this Music, and not the Harmonic of natural one, that one must seek the reason for the prodigious effects that it produced in the past. As long as one

\footnotetext{
231 Stevens, 2.

232 Stevens, 3-4.

233 Stevens, 5.

${ }^{234}$ Jean-Jacques Rousseau, Dictionary of Music, in Essay on the Origin of Languages and Writings Related to Music, trans. and ed. John T. Scott The Collected Writings of Rousseau, ed. Roger D. Masters and Christopher Kelly, vol. 7. (Hanover, N.H.: University Press of New England, 1998), 439.
} 
seeks moral effects in the physics of Sounds alone, they will not be found and one will reason without understanding. ${ }^{235}$

As the portraitist obscures her subject's imperfections with a well-placed stroke of the brush, the best musical imitations of nature highlight the most meaningful with a deft creative hand.

For Rousseau and other pro-Italian philosophes, one of the worst parts of French opera was the fact that it must be sung in French. In his Dictionnaire entry "Voice," he notes that "as the Italian Language is more Musical than the French, its speech is less distant from Singing; and it is easier to recognize the man one has heard speaking when he is Singing." ${ }^{236}$ In this way, Italian opera is closer to the natural sounds and accents of its language than the French. In addition, Rousseau and others railed against the French style of expository monologue. So out of step with real, human moments of passion, the French monologue tradition was further sullied by French operatic pronunciation. ${ }^{237}$ Staid, stodgy, and associated with the absolutism and artifice of the Sun King, wellknown French operas by Lully in the seventeenth and Rameau in the early eighteenth century did not hold a candle to 'modern' Italianate opera. ${ }^{238}$

For all Rousseau's nattering about the enhancement of nature to produce the profoundest sentiments, he did not particularly care for the castrati, and he does not devote much attention to them in his most prominent works. In his Encyclopédie article on the soprano voice, he says only "In vocal music the top is executed by women's voices, by children, and again by the castrati, whose voice goes up an octave by means of

\footnotetext{
${ }^{235}$ Rousseau, Dictionary, 439.

${ }^{236}$ Rousseau, Dictionary, 482.

237 Stevens, 20; 23.

238 Stevens, 26.
} 
this mutilation. See Castrati. ${ }^{239}$ Considering his staunch and prolific opinions on so

many subjects, Rousseau has surprisingly little to say about the Italian superstars.

Likewise, Louis de Cahusac, who penned the Encyclopédie article on singers, also says

very little about the castrati:

There are several castrati in the King's chapel, which are drawn early from the schools of Italy, and which sing in the soprano parts in the motets. Louis XIV had special kindness for them; he allowed them to hunt in his captaincies, and sometimes spoke to them with humanity. This great king took pleasure in consoling these wretches on the barbarity of their fathers. ${ }^{240}$

The main Encyclopédie article on Opera, written by Jaucourt presents a history of

the artform, which he notes originated in Italy while making no mention of the castratis'

significant role at all. Following the conventional thinking of the time, Jaucourt echoes

Rousseau's opinion on opera and sentiment:

But as it has been thought expedient to combine singing and music with these marvels [stage machinery and other spectacles], and that the natural material of musical singing is sentiment, the artists have been obliged to treat action to arrive at the passions, without which there is no music, rather than the passions to arrive at the action; and consequently the language of the actors had to be entirely lyrical, to express the ecstasy, the enthusiasm, the intoxication of sentiment, so that music could produce all its effects. ${ }^{241}$

239 "Dans la musique vocale le dessus s'exécute par des voix de femmes, par des enfans, \& encore par des castrati, dont la voix gagne une octave en-haut au moyen de cette mutilation. Voyez Castrati." Jean-Jacques Rousseau, "Dessus, \& en italien soprano [Musique]," in The ARTFL Encyclopédie, vol. 4, p. 895-96.

240 "Il y a à la chapelle du Roi plusieurs castrati qu'on tire de bonne heure des écoles d'Italie, \& qui chantent dans les motets les parties de dessus. Louis XIV. avoit des bontés particulieres pour eux ; il leur permettoit la chasse dans ses capitaineries, \& leur parloit quelquefois avec humanité. Ce grand roi prenoit plaisir à consoler ces malheureux de la barbarie de leurs peres." Louis de Cahusac, "Chanteur, euse [Musicien]," in The ARTFL Encyclopédie, vol. 3, p. 145.

241 "Mais comme on a jugé à propos de joindre à ces merveilles le chant \& la musique, \& que la matiere naturelle du chant musical est le sentiment, les artistes ont été obligés de traiter l'action pour arriver aux passions, sans lesquelles il n'y a point de musique, plutôt que les passions pour arriver à l'action ; \& en conséquence il a fallu que le langage des acteurs fût entierement lyrique, qu'il exprimât l'extase, l'enthousiasme, l'ivresse du sentiment, afin que la musique pût y produire tous ses effets." Louis de Jaucourt, "Opera [Belles-Lettres]," in The ARTFL Encyclopédie, vol. 11, p. 494. 
The effect created by the combination of music with heroic, tragic, heart-gripping drama was clear to Jaucourt, who sums up this section of his article by stating, "Since the pleasure of the ear becomes the pleasure of the heart, from there was born the observation that we will have made, that the verses singing affect more than words alone ... here is the origin and performance of our opera, the magical spectacle."242

Such descriptions are certainly more literary than scientific, though even a brief review of literature by Diderot, d'Alembert, Rousseau, and Jaucourt shows they had an excellent grasp of contemporary concepts on the physiology of sensibility. This was due in part to their relationships with physicians, who would have been part of their same social circles, frequenting the same salons. If their physiological knowledge came second-hand, there were also many physicians who took an interest in music's effect on the body as a part of their work on the senses and the mechanism of sensibility. These included Claude-Nicholas Le Cat's Traité des Sens published in French in 1740, JeanBaptiste-Joseph Lallemant's Essai sue le Mechanisme des Passions in 1751, and JosephLouis Roger's Traité des Effets de la Musique sur le Corps Humain, published in Latin in 1758 and later translated into French.

These texts all combine new physiological concepts of the nerves with popular conceptions of emotion and sensibility, with the occasional piece of music history or criticism thrown in for good measure. The authors also recognized, and specifically talk about, the way that emotions produced by outside sources can be a double-edged sword. Lallemant's Essai is the broadest of the three, and clocking in at nearly 300 pages, it

\footnotetext{
242 "Puisque le plaisir de l'oreille devient le plaisir du coeur, de-là est née l'observation qu'on aura faite, que les vers mis en chant affectent davantage que les paroles seules. . . . voilà l'origine \& l'exécution de nos opéra, spectacle magique ..." Jaucourt, “Opera [Belles-Lettres]," vol. 11, p. 494.
} 
presents an overview of the passions from both a medical and metaphysical perspective.

The first section of the text is devoted to the "physical and efficient causes of the passions," and includes a section on music, entitled "Music considered as an occasional cause of the Passions" in which he covers music history, music theory taken predominately from Rameau, and sections on the different effects of melody versus harmony, a chief point of debate for Rameau and the philosophes. He notes that chromaticism and dissonance should only be used briefly, on chromaticism he states:

The chromatic [scale], or the progression of sounds by semi-tone, carry a character of languor: It is an expression of sadness. It is not surprising that the chromatic [scale], from M. Rameau, excites the sad and dolorous Passions. The impression which allied tones in the order of the chromatic system produces on the organs of the internal senses hardly differs from those which naturally excite sobs and groans. Moreover, dissonances have in themselves something hard which cannot but produce on our organs a disagreeable sentiment. It's a violence that is done to them. Violence which in some manner approaches pain. In consequence, the animal spirits are pushed on the fibers with intensity and confusion. The subtle passage of one tone to another accompanied by a dissonance augments this intensity, because the impression which makes on the senses the foreign objects, is always the more intense, that is the least expected. ${ }^{243}$

In other words, because chromatic and dissonant sounds mimic the natural, well-known sounds of distress, they act upon the body in the same way, producing similar results within the listener.

\footnotetext{
243 "Le chromatique ou la progression des sons par semi-tons port un caractère de langueur: c'est une expression de doleur. Il n'est pas étonnant que le chromatique, suivant M Rameau, excite les Passions tristes and douloureuses. L'impression que les sons alliés dans l'ordre du système chromatique doivent produire sur les organes des sens internes, ne diffère presque pas de celle qu'y excitent naturellement les sanglots \& des gémissements. De plus les dissonances one en soi quelque chose de dur qui ne peut produie sur nos organes qu'un sentiment désagéable. C'est une violence qu'on leur fait. Violence qui approche en quelque manière de la douleur. En conséquence les esprits animaux sont poussés sur les fibres avec vivacité $\&$ confusion. Le passage subit d'un ton à une autre accompagné d'une dissonance augment cette vivacité, parce que l'impression que font sure les sens les objets étranges, est toujours d'autant plus vive, qu'elle est moins attendue." Jean-Baptiste Joseph Lallement, Essai sur le mécanisme des passions en général (Paris: Chez Pierre-Alexandre Le Prieur, 1751), 31-32. Google books digital facsimile.
} 
Roger's Traité focuses solely on music and the senses. At 350 pages long, the Traité consists of two parts, the first of which describes the mechanism of sound from various instruments (e.g. bells, wind instruments such as flutes), while the second contains a history of what he calls iatric music (musique iatrique) or music used as medicine. In this second he also explores the role of harmony and rhyme in iatric medicine. Roger sums up the last two sections on the mechanical action of music on the human body and the action of musique on the soul, respectively, with the following words:

We have seen that music acts on the soul in an infinite number of ways, and that often the action of sounds over matter concurs with their action on the soul, to produce in the animal economy those beneficial effects of which we have spoken. We have seen what these effects would be if music acted on the soul or body separately, or on these two substances in the laws. ${ }^{244}$

Just like a pharmacist's tonic, correctly composed and administered music could soothe the body and soul.

Le Cat offers similar sentiments on the salubrious effects of music:

This Power, which Musik has of moving the Soul, and by her Means the whole Machine, renders it very conducive to the Recovery of Health ... The Generality of Disorders consist in an Alteration of the animal Fluid, and its being affected by perverse Modifications. This Fluid is the Soul of Sensations and Passions; and it is owing to the Organs it receives the Impressions of Objects, and take the greatest Past of its Characters and Modifications. The Senses then are Organs very well adapted for changing the Character of this Fluid, and consequently exciting the whole Machine, which it animates, happy Revolutions. ${ }^{245}$

\footnotetext{
244 'Nous avons vu que la musique agit sur l'ame d'une infinité de manières, et que souvent l'action des sons sur la matière concourt avec leur action sur l'ame, pour produire dans l'économie animale ces effets avantageux dont nous avons parlé. Nous avons vu quels seroient ces effets si la musique agissoit sur l'ame ou sur le corps séparément, ou sur ces deux substances à la lois." Joseph-Louis Roger, Traite des Effects de la Musique sur le Corps Humain, trans. Etienne Sainte-Marie, (Paris: Chez Brunot, Librarie, Grenelle-St.Honoré, 1803), 251. Google books digital facsimile.

${ }^{245}$ Claude-Nicholas Le Cat, A Physical Essay on the Senses, Translated from the French of M. Le Cat (London: R. Griffiths, 1750), 60. Google books digital facsimile.
} 
Le Cat provides both modern anecdotes as well as ancient myths and Biblical stories to illustrate his point on music-as-medicine. While these may appear quaint, Le Cat was still a trained physician, and the majority of his treatise reflects his professional background with detailed anatomical discussions of the sense organs.

The medical and philosophical works examined here are quite similar in their approaches: the authors all provide case studies and anecdotes and medical details based on contemporary physiology, combined with philosophy and opinions on art, music, and religion. More than anything, perhaps, they show the modern reader how close relationships between men of letters in the eighteenth century facilitated the spread of ideas from one genre to the next, even extending beyond genre so that the musician's thoughts on medicine and the médecin's thoughts on music make their respective works nearly indistinguishable. They all agreed that the vibrations of music stimulated the nervous system, creating real physical reactions to the sound. Beyond this, they connected these internal corporeal vibrations to their subtler effects on the so-called animal or animating fluids which work in accordance with the emotions, as sounds trigger memories and past emotions associated with them. They then took this theory a step further, reasoning that if sounds in general and music in particular are received by body though vibration, changing the vibration - tone, consonance, dissonance, or volume, to name a few possible factors - the composer or performer has the ability to change a person's body, if only temporarily.

Here lies the power of music: it can soothe deranged passions through careful application, or excite the senses past the point of moderation. 
In 1919, music critic Francis Rogers penned an article on the history of the castrati for a relatively new publication called The Musical Quarterly. ${ }^{246}$ Summarizing

the castrati in the eighteenth century, he states:

Just as in the boy's voice we note the lack of the passion that stirs our deeper natures, so the voice of the male soprano must have been similarly deficient. In this we find one reason for the superficiality, the artificiality of all the music, except some of Handel's, that was written for the castrati. But the eighteenth century did not seek sincerity and profound feeling in any kind of art so much as it prized a facile technique and elegance of style. ${ }^{247}$

While Rousseau and his fellow philosophers would take extreme exception to Rogers' last statement, they might agree with the rest. Artificiality in music, and by extension the artificiality of the castrati, diminished the hearer's ability to truly feel the music. It also affected the hearer's ability to have the true, unadulterated emotions associated with experiencing nature — or at least at art that was declared 'true to nature.' French arguments against the castrati date back to 1659 , when the Abbé Perrin, an original member of the brand new Académie, dismissed Italian opera's entire style along with its featured singers. ${ }^{248}$ Among the members of the coin de la reine, who proclaimed Italian opera elicited the stronger passions and purer emotions, the castrati posed a serious threat to their argument. What is more representative of Italian opera than the castrati? And what is more artificial than a castrated male soprano playing the amorous hero?

\footnotetext{
${ }^{246}$ Currently published by Oxford Journals, The Musical Quarterly is the oldest American academic journal on music. First published in 1915, its writers have included well-known composers such Aaron Copeland and Camille Saint-Saens among its authors. The journal regularly includes articles on musicology, reviews of new books on music, and important musical recordings and performances. https://academic.oup.com/ma/pages/About

${ }^{247}$ Francis Rogers, "The Male Soprano," The Musical Quarterly 5, no. 3 (July 1919): 424.

${ }^{248}$ Alano, 127.
} 
Even Ancillon was caught up by the artistry of the castrati; momentarily setting his disgust for the castrated body aside, Ancillon occasionally loses himself in memories of music. Recalling a trip to Rome in 1705 , he tells the reader that he attended the performances of three famous castrati, namely Pasqualini, Pauluccio, and Jeronimo, stating, "it is impossible to give any tolerable Idea of the Excellencies of these Three Celebrated Eunuchs, or the Beauty of their several Voices: In Short, they are above description. ${ }^{249}$ Nevertheless, Ancillon endeavors to recount the experience for the sake of the reader:

In short, they are all three so excellent in their kind, that a Man does not know which he likes best; for after the Masterly Performances of Pasqualini, which strike you with Admiration and Wonder, you are ravished with the high Warblings of Pauluccio, and when you think you are almost satiated with those Luxuriancies of Sound, you are most agreeably charmed a new [sic] with the soft Strains of Jeronimo (which I have sometimes almost imagined have been not unlike the gentle Fallings of Water I have somewhere in Italy often heard) lulling the Minds into a perfect Calm and Peace. ${ }^{250}$

He continues in this vein for eight pages before rousing himself from his sensual reverie and diving once more into the clinical and morally reprehensible history behind the great voices. And yet, for a few pages, Ancillon becomes a man wrapped up in the sensibility of his memories, recalling the voices of these men with the language one might reserve for the tender actions of a lover. It smacks of hedonism, voluptuousness, and an intimate knowledge of the senses' role in the production of pleasure. Such strong responses to musical stimuli were common, if the large body of writings on music and sensibility are to be believed. Personal journals and correspondence, published fiction, musical

\footnotetext{
${ }^{249}$ Ancillon, 30.

${ }^{250}$ Ancillon, 31.
} 
querelles, and medico-philosophical treatises could all agree on one thing at least: music has the power to literally change the human body.

In eighteenth-century France, the gens $d u$ monde went to the opera to see, be seen, and occasionally listen to some music. Whose opinion on music mattered, and what role music played in society, was a constant point of discussion for the encyclopedists, moralists, and le publique at large. As the physiological concept of sensibility gained traction among the learned and upper classes, the medical and scientific ramifications of music found more attention as well.

The figure of the castrato, only a small part of the Querelle des Bouffons itself, was intimately tied to the questions at the heart of the Querelle specifically and midcentury debates more generally: how much 'nature' should take precedence over artifice and the ways in which music could harm or heal the emotional and physical body. In France, pro-Italian opera was not equivalent to pro-castrati; emblematic of deeper questions on sensibility, consumption, luxury, the castrati were still viewed by many philosophes as the embodiment of cultural degeneration. In addition, the unnatural power of the castrato's voice could, based on the common theories on sensibility and music, raise the spirits of the dolorous or overly excite the passions to the point of derangement. The castrati could exert more power in this area than unenhanced singers, and therefore could be more dangerous to the health of the listener. 


\section{Chapter Four \\ "Luxuriancies of Sound": Castrati and the Discourse of Pleasure}

The taxonomic impulse did not begin and end with the sciences. In fact, philosophers and physicians of the long eighteenth century explored the hierarchy of pleasures as a part of the well-established disciplines like ontology and metaphysics as well as the growing fields of the sciences de l'homme (including what we now consider pseudo-scientific areas like physiognomy) that would eventually become sociology and psychology. At the heart of these academic pursuits was the debate over whether or not pleasure was a legitimate human pursuit, one that could potentially benefit society, or simply a human craving that must be controlled by theologians and legislators. ${ }^{251}$ Two of the main concerns were sexuality and the utility of art, music, and literature, both of which were intimately tied to the figure of the castrato during this time.

Returning to Burney's quote from the introduction, Farinelli's voice is described using language that would be quite at home in Anglo-Irish philosopher Edmund Burke's influential treatise $A$ Philosophical Enquiry into the Origin of Our Ideas of the Sublime and Beautiful —words such as "astonishing," "delightful," and "sublime." It is quite likely that Burney was influenced by Burke's treatise, whether directly or no; between

\footnotetext{
${ }^{251}$ Alexander Cook, "The Politics of Pleasure Talk in 18th-Century Europe," Sexualities 12, no. 4 (2009): 452. The subject of eighteenth-century sexuality has produced many thought-provoking works in the last several decades, many of which highlight the relationship between sex, contemporary debates on gender, and the role of 'nature' in morality. See Sander L. Gilman, Difference and Pathology: Stereotypes of Sexuality, Race, and Madness (Ithaca: Cornell University Press, 1985); Londa Schiebinger, "The Anatomy of Difference: Race and Sex in Eighteenth-Century Science," Eighteenth-Century Studies 23, no. 4, Special Issue: The Politics of Difference (Summer, 1990); and Kathleen Wellman, "Physicians and Philosophes: Physiology and Sexual Morality in the French Enlightenment," Eighteenth-Century Studies 35, No. 2 (Winter, 2002).
} 
1757 and 1798, at least six editions of Burke's Enquiry found their way into the hands of the public, each edition lengthier and more compendious than the last. ${ }^{252}$

Writings on the castrati often describe the feelings they created in the audience and ignore the emotions of the performers themselves. What about the pleasure of creating art? Of being beloved by strangers? For his treatise, Ancillon does not appear to have personally interviewed any castrati, and certainly would not have thought to ask such probing psychological questions. That said, in a moment of insightfulness, Ancillon pauses to consider the pleasure of the performer rather than the emotions and experience of the audience. He states, "for certainly, no fine voice can compensate for such a Loss for the Eunuch, whatever he may gain by it; nor give so much Satisfaction to the Audience, as may countervail the Encouragement of such Mutilations. ${ }^{" 253}$ And yet, it is obvious that many castrati forged meaningful relationships— both platonic and sexual— with others of their own kind. Having no biological offspring, castrati often left their estates to younger singers, who would in turn train, mentor, and associate with the next generation. $^{254}$

While the castrato may have loved the financial security and adoration he received from his audience, Ancillon sees no way in which this pleasure is equal to the potential of pleasure that he has lost. Sacrificed for art and the pleasure of others, the castrato's body was incapable of fully experiencing the pleasures of 'normal' heterosexual intercourse or the satisfaction derived from marriage and family, all of

\footnotetext{
${ }^{252}$ At least according to Eighteenth Century Collections online. Technically, the sixth edition was published in 1771; subsequent editions were simply called the "new" edition.

${ }^{253}$ Ancillon, 136.

${ }^{254}$ Rosselli, "The Castrati as a Professional Group," 178.
} 
which feature heavily in many Enlightenment treatises on love, pleasure, and happiness. Indeed, Ancillon shares a conversation with Pauluccio, the youth who was (allegedly) castrated against his will by his uncle, which roused the Frenchman's sympathy:

I told him one Day . . . that I thought him mighty happy, being so much respected by the greatest Quality, and living in the greatest Affluence and Plenty, the World at his Command, and had the Favour of Princes. He replied, with a deep sigh, and the Tears stood in his Eyes, Si, Signor ma si manca qualche Cosa, Yes, Sir, says he, but — there — is something wanting. ${ }^{255}$

In English, the double entendre is quite clear. There is something wanting indeed, and it is there.

\section{Unnatural Desire: The Castrati as Lovers}

Modern medicine has hotly debated whether or not the castrati were capable of any degree of penetrative heterosexual intercourse, as their castration took place before the onset of puberty. However, there is, and was, far more to the story of castrati sexuality than standard heterosexual intercourse. In their time, the castrati were desired by both men and women, seen as aggressor and prize, and accused of (and lauded for) participating in sexual practices that many considered 'against nature,' such as sodomy. Based on their status as unnatural men, one can assume that any sexual desire, contact, or experience with a castrato was considered an unnatural act; based on the fluidity of their on-stage gender presentation, it could even be seen as same-sex attraction.

${ }^{255}$ Ancillon, 40. 
For his part, Ancillon considered sexuality mainly in terms of procreation, not pleasure. He cites the biblical prophet Isaiah, calling the eunuchs "dry trees" and mentioning the words of Hosea in reference to Ephraim, "their root is dried up, they shall bear no fruit." ${ }^{256}$ Indeed, the entire second part of his treatise is an invective against marriage rites for eunuchs based on their inability to procreate, which was long considered the goal of matrimony for both the Catholic and (in more recent centuries) the reformed Christian churches. ${ }^{257}$ Ancillon sums up his point early on in section two with biblical exegesis, stating:

The Difference of Sexes, and these Words increase and multiply, which God himself pronounced when he joined them together, when he instituted Marriage, and blessed it, evidently demonstrate, that the End of that Union could be nothing else but the propagation mankind..$^{258}$

Despite this characterization, Ancillon's very motive for writing his treatise reveals another story:

The Motives that engaged me to write the ensuing Treatise were very singular. It is not long, since we saw several Italian Eunuchs ... who made a very great Figure, as they might very well do, getting such Sums of Money from those who they could not have imagined ... These unexpected Favors, puffed them up with a Vanity which is ever peculiar to Eunuchs, and some of them had got it into their Heads, that truly the Ladies were in Love with them, and fondly flattered themselves with mighty Conquests. But alas! Our Ladies have not so little natural Philosophy, but they know how to make a just Distinction, and have too fine a Goût, to be satisfied with meer [sic] Shadow and Out-fade. ${ }^{259}$

The notion that the eunuch was not truly a man — that he is in fact a demi-homme-adds to the ontological ambiguity that pervades Ancillon's work. This idea of the eunuch as a

\footnotetext{
256 Ancillon, 95.

${ }^{257}$ Ancillon, 139.

258 Ancillon, 141.

${ }^{259}$ Ancillon, v-vi. Emphasis belongs to the author.
} 
shadow of a man comes from the preface to his work, but this idea is quickly juxtaposed against the notion of the eunuch as pansexual libertine.

Perhaps one of the most problematic characterizations of castrati sexuality is the long-standing connection between the castrated male body and homosexuality. While effeminacy and dandyism were not always associated with homosexual desire, the connection between eunuchs and femininity had deep roots by the eighteenth century. In fact, Ancillon's very definition of "eunuch" concludes thus:

In short, Eunuchs are such, Qui generare non possunt, as the Civil Law expresses it. Such who can by no means propagate and generate, who have a squealing languishing Voice, a Womanish Complection [sic], and a soft Down for a Beard, who have no courage or Bravery of Soul, but ever timerous [sic] and fearful: In a few Words, whose Ways, Manners, and Customs, are entirely effeminate. ${ }^{260}$

Castrated youths were viewed as the plaything of debauched rulers, which Ancillon demonstrates by including Dryden's translation of Juvenal's tenth satire in his discussion of the motives behind castration in the ancient world: "We never read of such a Tyrant King/Who gelt a Boy deform'd—/Nor Nero in his most luxurious Age/ E'er made a Mistress of an ugly Page."261 Physically male but not masculine in the accepted sense, the castrated body was a source of homosexual pleasure similar to relationships between men and boys in the ancient world. And yet, the eunuch retained the softness of youth, tempered with the sexual knowledge and experience of an adult. Despite his age, the castrato was often categorized as a catamite because of his singular features.

In both France and England, sodomy was associated with Italian men. In France, those who practiced le vice italien were referred to euphemistically as members of the

\footnotetext{
${ }^{260}$ Ancillon, 8.

${ }^{261}$ Ancillon, 28. He includes the Latin in a footnote: "Nullus Ephebum/ Deformem scaeva castravit in arce Tyrranus." It is not as poetic as Dryden's version.
} 
secte de Rome. ${ }^{262}$ For the English, there was long-standing connection that pre-dated the first castrati performers, developing instead from the correlation between so-called sodomical practices and the absolutism so common with the continental aristocracy. ${ }^{263}$ This is most likely the reason why the English translation of Ancillon's work is titled "Italian Love." While it does not deal directly with the legal ramifications of sodomy, the Huguenot's treatise alludes in many places to the connection between effeminacy and sodomy, the "Italian vice."

A eunuch's (debatable) lack of potency also made him the perfect passive partner for the dominant, homosexual man, most often seen in the form of the libertine. In other words, the castrated man was penetrable but not penetrating, during a time when 'real' sex was seen as necessarily involving penile penetration. ${ }^{264}$ The castrato was an extreme version of the British fop, the confused sexual misfit of satirical plays and novels. ${ }^{265}$ For George E. Haggerty, scholar of gender in eighteenth-century literature, the fop was coded as a 'monstrous' figure, identified and minoritized by his effeminate nature. ${ }^{266}$ As the intact version of the eunuch, the fop was also seen as a libertine, the object of male aggression and pursuer of women in his own right. ${ }^{267}$ However, unlike the more masculine libertine, the fop was often used as comic relief, characterized as an

\footnotetext{
262 Prest, 156.

${ }^{263}$ King, 570.

${ }^{264}$ Prest, 157.

${ }^{265}$ George E. Haggerty, Men in Love: Masculinity and Sexuality in the Eighteenth Century (New York: Columbia University Press, 1999), 45.

${ }^{266}$ Haggerty, 44.

${ }^{267}$ Haggerty, 45.
} 
ambiguous figure who succumbs to the will of his social betters and more virile counterparts. ${ }^{268}$

The most well-known libertine of all, Giacomo Cassanova, also elaborates upon his understanding of virtuous behavior in libertinism in his (in)famous memoire Histoire de ma vie. While this titillating and highly entertaining book was not published until the 1820 s, Casanova's story gives the reader an intimate look at libertine practices in eighteenth-century Europe. Historian Ted Emery, who explored Casanova's life through a queer lens, notes that while Casanova's heterosexuality is never something that the Italian questions, he stages scenes within his memoir that "queer" his experience. This, Emery suggests, is an act of social subversion in which Casanova vicariously engages his readers in homosexual liaisons. ${ }^{269}$ This reading of Casanova's memoir certainly has merit, but it also suggests that the author's actions, whether overtly homosexual or not, were guided by a set of morals that in some respects mirrored the default guidelines for virtuous action, most especially as they related to homosexual activity.

Emery cites three instances of homosexual or quasi-homosexual liaisons in the Histoire, the most interesting of which involves a young nubile soprano masquerading as a castrato. Based on his intense attraction to the singer, Casanova guesses (and hopes) that they are indeed a young woman in disguise. When this turns out to be the case, Casanova's lust is justified because it was aimed at an appropriate vessel and did not transgress the common, appropriate, morally correct hierarchy of sexual behavior. ${ }^{270}$ To

\footnotetext{
${ }^{268}$ Haggerty, 45. For Haggerty, the difference between the fop-libertine and his counterpart is that the latter is never the subordinate partner. (Haggerty, 8.)

${ }^{269}$ Ted Emery, "Queer Casanova: Subversive Sexuality and the (Dis)embodied Subject in 'History of My Life."' Italian Culture 24/25 (2006-2007): 24.

${ }^{270}$ Emery, 36.
} 
put it another way, Casanova is obviously relieved that he has not broken his rules, despite seducing a person of visually ambiguous gender. At one point Casanova is horrified by what he assumes is either a castrato's penis or a massive clitoris, hoping for the latter despite the social stigma that would accompany such an appendage. When he finally seduces the castrato and makes him/her reveal her secrets, he discovers that the organ he felt was nothing more or less than a stuffed piece of animal gut, attached with glue to the pudenda, meant to fool others into believing that she was male. ${ }^{271}$ Here, Casanova gambled and won, keeping his actions well within his own set of moral guidelines.

Ancillon calls eunuchs "meer [sic] shades" at the beginning of his treatise because they cannot procreate, but also suggests that liaisons with them are dangerous for society because sexual intercourse with a eunuch is risk-free for women, leading members of the fair sex down a path of lust and debauchery. For historian Julia Prest, this link between sex and reproduction reveals a social anxiety regarding sexual desire, especially on the part of women. ${ }^{272}$ For this portion of her study, she focuses on the work of Ancillon, who very clearly suggests that the wives and lovers of eunuchs had unnatural proclivities:

A Woman who lies by the Side of such a Man (if I may call him so) would languish and pine away; in vain does she try to excite him to render what's her Due; all her Efforts are vain and useless, she can never succeed; so that having not tasted the Joys of Marriage, nor having any appearance that she ever shall, she pines and afflicts herself in Secret; nor is this without Example. ${ }^{273}$

Prest asserts that the term "afflicts herself" is a subtle way of suggesting that a woman in this position would take to masturbation in order to satisfy the desires that her husband

\footnotetext{
${ }^{271}$ Emery, 38.

272 Prest, 158.

273 Ancillon, 165.
} 
could not. ${ }^{274}$ Ancillon follows his statement with an anecdote from antiquity, the story of the Emperor Constantius and his wife Eusebia. Her husband is described as having an effeminate constitution; his wife Eusebia, though young and beautiful, pined away and died young, ending her days 'hectick, dry'd-up, and disfigured, thro' an inward Chagrin and Discontent, of never having the sweet and agreeable Conversation and Caresses of an [sic] husband. ${ }^{275}$ Indeed, these are the same terms that were applied to victims of chronic masturbation, which makes Prest's conclusion the likely one.

If the wife of a castrato did not adopt the dangerous vice of self-gratification, she would likely turn to an even greater sin, adultery. On this point Ancillon is quite succinct, stating, "And it would be a Matter of no great Surprize [sic], if a Woman, that does not find at Home, wherewithal to satisfy provoked Passion, should receive elsewhere, what may be necessary to lay and becalm its rage and fury." ${ }^{276}$ Some eunuchs, he mused, would marry women of such a temperament on purpose, so that they could profit from their wives' inclination towards "libertinism and debauchery" by earning advantages, either monetary or social, through prostitution. ${ }^{277}$ In other words, the unnatural body of the eunuch would create a sham marriage that tolerated — and even celebrated — the worst traits of women. While a natural marriage, which Ancillon saw as one that produced children, elevated women through motherhood, a castrato marriage disallowed such a possibility. This in turn would erode the morals of the woman, the marriage, and society as a whole by tacitly condoning deviant sexual practices.

\footnotetext{
${ }^{274}$ Prest, 159.

${ }^{275}$ Ancillon, 165. In many parts of Europe, castrati were not allowed to marry at all because they were unable to procreate.

${ }^{276}$ Ancillon, 167.

277 Ancillon, 170.
} 
Prest also points out that scholarship on castrato sexuality has focused mainly on penetrative sex, ignoring the possibility that heterosexual couples could engage in satisfying sexual experiences through manual or oral sexual encounters, referred to as the secret des Lesbiennes in works by men like Cassanova. ${ }^{278}$ This is generally true, but it was not a secret to men like Ancillon either, who paradoxically asserts both that women would stray or wither if married to a eunuch, while also suggesting that such men would be able to satisfy the sexual desires of women. However, he does not admit that such a union would be natural, normal, or healthy, stating:

[I]t is certain than an Eunuch can only satisfy the Desires of the Flesh, Sensuality, Impurity, and Debauchery; and as they are not capable of Procreation, they are more proper for such criminal Commerce than perfect Men, and more esteem'd for that Reason by lewd Women, because they can give them all the satisfaction without running any Risk of Danger. ${ }^{279}$

Against the natural laws of sexuality and procreation, castrato sex offered only pleasure. Indeed, Ancillon employs this type of language, juxtaposing what was "lawful" and what was not, stating that "the lawful desires of a Woman are to have Children."280 Therefore, when women engage in sexual acts that have no chance of fulfilling this need, they are unlawful and "cannot be permitted even in the State of Matrimony, where if any where [sic] they would be justifiable." ${ }^{281}$ In other words, marriage to or congress with eunuchs had no place in society. Breaking the law of nature is a worse crime than breaking the laws of man, and Ancillon saw marriage to a eunuch as doing both.

\footnotetext{
278 Prest, 158.

${ }^{279}$ Ancillon, 202.

${ }^{280}$ Ancillon, 204.

${ }^{281}$ Ancillon, 203.
} 
If most governments of Europe made it illegal for eunuchs to marry, historians have uncovered several instances of such unions. One, the marriage of Giusto Tanducci and Mary Holland in Dublin, 1766, caused a scandal when it became public. Helen Berry, historian of sexuality at Newcastle University, has used this instance to explore the performative nature of marriage and gender, arguing that the binary we associate with gender is the basis for organizing modern culture. ${ }^{282}$ If theologians and moralists have long lamented the degeneration of the strict oppositional pairings of male/female, dominant/passive, the actual history of gender and sexual practices shows that the reality has always been far more fluid. While it seems unlikely that the marriage between Giusto and Mary was ever consummated in the traditional and legal sense- - their marriage was, in fact, annulled by Mary on these grounds - this was not always the case. ${ }^{283}$

It was easy for those concerned with the health of the soul to lambast those who engaged in non-penetrative and non-heterosexual sex, and Ancillon was not the only eighteenth-century writer interested in the implications of taking a castrati lover. In their groundbreaking work Sexual Underworlds of the Enlightenment, Rousseau and Porter note that eighteenth-century authors were fascinated by body literature featuring those deemed physically or sexually abnormal. Literature on eunuchs dates to at least the Ancient Greeks, and in the eighteenth century these texts often explored explicit sexual themes; in the 1720s and 1730s, when public acclaim for famous castrati such as Farinelli and Senesino was at its height, publishers produced a spate of eroticized satirical texts

\footnotetext{
${ }^{282}$ Helen Berry, "Queering the History of Marriage: The Social Recognition of a Castrato Husband in Eighteenth-Century Britain,” History Workshop Journal 74 (Autumn 2012), 30.

${ }^{283}$ Berry, 41.
} 
featuring the performers. ${ }^{284}$ Rousseau and Porter point to a text from later in the century as well, a 1762 collection of "histories" that includes a story about a lonely and amorous wife, Lady Lucian, who takes her castrato music master as a lover; a similar story appeared in an English magazine 1783, showing that even as their popularity began to wane, the castrati were still an object of titillation. ${ }^{285}$

The topic was also taken up by doctors in the eighteenth century, warning of the physical risks of so-called deviant sexual practices through books and pamphlets. Swiss physician Samuel Auguste David Tissot's work on masturbation, which is discussed later in this chapter, has received much attention from historians and sociologists, but other medical treatises address these issues as well. Interestingly enough, a relatively obscure mid-century work on barrenness and impotence mentions both masturbation and sexual congress with eunuchs. In his treatise entitled The Nature and Causes of Impotence in Men, and Barrenness in Women, Explained ... Irish physician G. Archibald Douglas states:

[Eunuchs] prepare the same liquor, and the pressing of them will bring it out: therefore these persons are capable of performing all the office of men, except that of begetting children: and they even have a liquor to discharge, tho' it be not of the right kind. This has recommended eunuchs highly among the bestial part of their country women; and with other unnatural vices, they have taught some of ours. But there is this consequence, which most who have indulged themselves in that most shameful prostitution have found to their misery, that although eunuchs cannot beget children, they can occasion false conceptions. It is for this reason the Italian women are more subject to them than others; and the people about an Italian theatre most of all. ${ }^{286}$

\footnotetext{
${ }^{284}$ G.S, Rousseau, and Roy Porter, eds., Sexual Underworlds of the Enlightenment (Chapel Hill, NC: University of North Carolina Press, 1988), 58. Modern cultural historian George S. Rousseau should not be confused with Jean-Jacques Rousseau, our eighteenth-century polymath.

${ }^{285}$ Rousseau and Porter, 56.

${ }^{286}$ G. Archibald Douglas, The nature and causes of impotence in men, and barrenness in women, explained ... 3rd edition (Dublin, 1758), 19. Eighteenth Century Collections Online. Douglas also relates the curious
} 
By engaging in sexual congress with a eunuch—Douglas seems quite certain that penetrative sex is possible in this situation — the woman put herself at risk for a shameful and dangerous consequence. Here we see a monster, the castrated man, begetting the monstrous birth that Douglas refers to as a false conception; the lump of flesh serves as a product of their deviant, twisted, and highly unnatural union. This in itself can be seen as the shadow of the consequences of natural yet inappropriate sexual behavior: sexual congress outside of wedlock, and the birth of an illegitimate child. Implicit in Douglas's warning about false conceptions is the notion that women should not and cannot be allowed to engage in risk-free sexual behaviors. By insinuating the 'risk' of this (albeit temporary) physical deformity, Douglas has at once tried to normalize these relations while also showing that sexual commerce with a eunuch can lead to unnatural consequences. If the perils of pregnancy are avoided by deviant sexual practices, the danger to society is increased.

Ancillon and Burney's works were published seventy years apart, but they shared many similar views on castration: most importantly, both the jurist and the music scholar agreed it was a practice that went against nature because it fundamentally altered the biological usefulness of the men who came under the proverbial knife. Paradoxically, both abhorred the practice but loved and admired the castrati they met and saw upon the stage. Effeminate yet powerful, the castrato was a confusing symbol of both (or either)

\footnotetext{
story of a plantation widow in the West Indies who became "pregnant" after excessively masturbating with
} the aid of a plantain. 
the pinnacle of an art and the nadir of a decaying, debauched society in eighteenthcentury moral and philosophical discourses on sexual behavior.

As the operatic symbol of the young lover, the castrati were desired by both men and women; their ambiguous sexuality was both an allure and a sign of their unnatural state, confounding and titillating the public. Because of their liminal status as 'men,' neither unsexed children, women, nor fully-formed males, the castrati's sexual escapades with both sexes were by definition unnatural. Like the monsters we met in chapter two, the castrati defined 'natural' sexuality by what they so obviously lacked. In sexual congress with men, they were seen as the modern embodiment of the catamite, with the appetites and experiences of a grown man and the softness of a pre-pubescent boy. Their sexual ability — characterized in this era by their ability to penetrate other bodies — was a source of constant public debate, and the question of whether and how they could sexually gratify women made them simultaneously impotent cuckolds and sweet-voiced lotharios.

Castrato sexuality was a threat to social order because it offered women risk-free pleasure. With the fear and stigma of pregnancy set aside, the bestial nature of unbridled female sexuality could unravel the fabric of society, the pleasure of motherhood eclipsed by the debauched pleasures of the flesh. Herein lies another paradox: while women were seen as being naturally more sexual than men, being too sexual or involved in nonpenetrative or non-heterosexual sex made their desires 'unnatural.' 
2. Dangerous Pleasures, Monstrous Vices: Onanism, Utility, and the Castrato's Body

Dangerous and unnatural as the pleasure of castrato sex may have been, few women were likely to fall within their clutches. Such fears garnered far less attention than another form of supposedly consequence-free gratification: masturbation. As with the stories of debauched, over-sexed castrati and their paramour/victims, the great masturbation scare of the eighteenth century was grounded in concepts of naturalness and utility. Engaging in sexual acts with castrated men, especially mutual manual stimulation, was also connected to the other public-health horror of the eighteenth century: masturbation.

Masturbation was certainly not seen useful in the biological sense as it would not lead to the production of offspring, but debates on whether or not it was 'natural' continued through the eighteenth century well into the present day. But, here again, we find the castrati as the embodiment of a dangerous social disease: they appear in antimasturbation tracts with surprising frequency as both examples of the 'naturalness' of masturbation and as bogeymen once again upsetting the sexual status quo. Prest notes that masturbation was often associated with opera in late seventeenth-century English pamphlets; listening to the castrati was seen as a form of musical masturbation, which could lead the undisciplined listener into satisfying their baser urges after the end of the performance. ${ }^{287}$ More importantly, though, masturbation was considered a form of

${ }^{287}$ Prest, 156. 
sodomy along with (partnered) manual, oral, and anal sex. ${ }^{288}$ Linked together as deviant acts, moralists saw all non-procreative sex as unnatural: its connection with the unnatural and effeminized body of the castrato would have made the danger of such acts doubly 'unnatural' for moralists and theologians.

In recent decades, scholarship on sexuality in the long eighteenth century has shown that the long-standing notion that voluptuousness had free reign over society is not entirely accurate. As physicians and medical theorists took an increasing interest in physiognomy, the one-sex system that dominated western medicine for thousands of years began to transform into the two-sex model. Women were no longer deformed versions of men, they were different creatures entirely. ${ }^{289}$ One result of this paradigm shift was increased pressure to define what was natural sexual behavior, and what were the natural properties and operations of heterosexuality. ${ }^{290}$ By redefining the human species as two distinct types of bodies, physicians, philosophes, and moralists contributed to yet another paradox, here, discrimination based on gender contrasting the lofty ideal of universal liberty. ${ }^{291}$ That said, there was one place where men and women's sexuality were equal: both were guilty of the heinous crime of self-pollution, commonly known as masturbation. ${ }^{292}$

\footnotetext{
${ }^{288}$ Prest, 157. Depending on time and place, the exact definition of "sodomy" changed. However, all of these acts were historically seen as deviant and sinful by the Catholic and Reformed churches, as well as by many European governments.

289 Thomas Laqueur, Making Sex: Body and Gender from the Greeks to Freud (Cambridge, MA: Harvard University Press, 1990), 149-54.

${ }^{290}$ Karen Harvey, "The Century of Sex? Gender, Bodies, and Sexuality in the Long Eighteenth Century," The Historical Journal 45, no. 4 (December,2002): 906.

${ }^{291}$ Harvey, 902.

${ }^{292}$ Throughout this discussion I use the pronoun 'he' unless specifically discussing women. Because of the differences in their reproductive organs and basic physiological nature, symptoms varied slightly between
} 
Commonly referred to as 'self-pollution' during the medieval period, this ancient vice acquired a new life after the Council of Trent, beginning in 1545 . While these sixteenth-century condemnations of so-called 'deviant' sex tended to focus on men engaging in sodomy and other homosexual acts, theologians also began acknowledging the importance of pleasure between married partners. ${ }^{293}$ Both of these re-evaluations of sexual behavior were, according to historian Pierre Hurteau, a part of the broader trend towards personal responsibility and self-reflection for men and women living outside the walls of convents and monasteries. ${ }^{294}$ In addition, this change in explanation was couched in terms of reason, not just sin; moral weakness, which led to adultery and all forms of sodomy, was the result of a lack of personal mastery over one's body. ${ }^{295}$

The majority of early modern Catholic moralists, therefore, believed that mastering one's psyche was key to sexual continence. A lack of ability to control one's erotic thoughts was considered dangerous, for both the health of the individual and for society at large. ${ }^{296}$ Loss of self-control—-first of the mind and, though lack of mental discipline, the loss of one's bodily autonomy to the desires of the flesh—was at the heart of the changing conception of self-pollution.

The final thrust from medico-moral debate to social terror began in the early decades of the eighteenth century with the publication of Onania, written by an

\footnotetext{
men and women, but overall were the same. That said, the main premise here - that frequent masturbation destroyed the mind and the body — held true for both sexes.

${ }^{293}$ Pierre Hurteau, "Catholic Moral Discourse on Male Sodomy and Masturbation in the Seventeenth and Eighteenth Centuries," Journal of the History of Sexuality 4, no. 1 (July 1993): 6.

${ }^{294}$ Hurteau, 8,

${ }^{295}$ Hurteau, 2.

${ }^{296}$ Hurteau, 18.
} 
anonymous Englishman. ${ }^{297}$ Historian of science Patrick Singy suggests that, while Onania may have sparked the wide-spread panic early in the century, it had more in common with the moral discourses from the Early Modern period than with the more secular l'Onanisme, first published in French in $1760 .{ }^{298}$ The latter, which was published with the full title L'Onanisme: Dissertation sur les maladies produites par la masturbation, was originally written in Latin by physician Samuel August David Tissot in $1759 .{ }^{299}$ It was in the hands of this well-established and highly-esteemed doctor that masturbation became a mainstream problem. ${ }^{300}$

In his extensive, groundbreaking study on the cultural history of masturbation, historian Thomas Laqueur discusses at length the three ways in which masturbation became the touchstone of modern moral panic in the West. Unlike partnered intercourse, masturbation was private, or, if not done alone, was done in the 'wrong kind' of company — taught to young children by devious servants, or as information passed within in the confines of boarding school. In addition, unlike other sexual practices, the urge to masturbate was seen as something that could never be fully satiated and was not moderated by the rational mind. Most importantly for this study, Laqueur states that solitary sex was motivated "not by a real object of desire but by a phantasm;

\footnotetext{
${ }^{297}$ The actual year of publication is still up for debate as no first editions are extant. Stengers and Van Ness suggest the last few months of 1715; Jean Stengers and Anne Van Ness, Mastubation:The History of a Great Terror, trans. Katheryn A. Hoffman, (New York: Palgrave, 2001), 3. Michael Stolberg dates the first edition to 1716, while citing that other historians offer 1710 as the year of original publication. Michael Stolberg, "Self-Pollution, Moral Reform, and the Venereal Trade: Notes on the Sources and Historical Context of 'Onania' (1716)," Journal of the History of Sexuality 9, no. 1/2 (January-April 2000): 38-39. ${ }^{298}$ Patrick Singy, "Friction of the Genitals and Secularization of Morality," Journal of the History of Sexuality 12, no. 3 (July 2003): 346 . This is one of the few articles on the subject written by a historian of science.

${ }^{299}$ Thomas W. Laqueur, Solitary Sex: A Cultural History of Masturbation (New York: Zone Books, 2003), 38.

${ }^{300}$ Laqueur, Solitary Sex, 40.
} 
masturbation threatened to overwhelm the most protean and potentially creative of the mind's faculties - the imagination — and drive it over a cliff." ${ }^{301}$ Like the castrato sex which could never produce children, self-pleasure had no utilitarian, physical value, which made it morally suspect.

Laqueur properly situates the masturbation terror within these societal concerns, but he does not address the deeper issue here. He certainly shows that solitary sex was considered dangerous because it was a bad way to use the imagination. However, he does not take this thought to its full conclusion. As mid-century authors like Tissot state, it is not all masturbation that is sinful or a threat to society. In fact, in certain situations it was considered absolutely necessary. Therefore, it would be more correct to state that masturbation only for pleasure was misuse of the body and of the imagination. It was not useful either for society or for the individual to use the most human of faculties, the imagination, for this purpose.

French physician Jean-Joseph Menuret de Chambaud, the likely author of the Encyclopédie article on masturbation, was certainly influenced by Tissot's work. Trained at Montpellier, Menuret de Chambaud moved to Paris after finishing his medical training, where he continued his medical research alongside vitalists, including Theophile de Bordeu. In the early 1760s he was recruited to write for the Encyclopédie by Venel, who was reportedly overwhelmed by the volume of medical articles needed for the project. Menuret de Chambaud contributed over 80 articles on medicine, making him one of the most prolific encyclopedists. ${ }^{302}$

\footnotetext{
${ }^{301}$ Laqueur, Solitary Sex, 210.

302 Kafker and Kafker, "Menuret de Chambaud, Jean-Joseph,” 254-55.
} 
While maintaining the horrified attitude towards his subject en générale, Menuret de Chambaud cites the habits of the ancients as proof that masturbation had not always been the dangerous vice that it had become in the modern era. After leaving the moral theorizing to the theologians, he states:

It is in this sense that we say that masturbation which is not frequent, which is not excited by a boiling \& voluptuous imagination, and which is finally determined only by the need, is followed by no accident, and is not an evil (in Medicine.) Moreover, the ancients, judges a bit too serious and scrupulous, thought that when it was contained in these bounds, one did not violate the laws of continence. ${ }^{303}$

Indeed, the ancient medical and philosophical authorities - however inaccurate their overall theory of the body appeared to eighteenth-century physicians—offered themselves up as models of continence:

Thus Galen does not find it difficult to say that this infamous cynic (Diogenes), who had the impudence to resort to this shameful practice in the presence of the Athenians, was very chaste, in respect to the steadfastness of continence; because, he continues, he did it only to avoid the inconveniences that the retained seed can cause. ${ }^{304}$

So, as in the oft-quoted and entertaining anecdote about Diogenes, the reader is told that men who are able to maintain moral and rational continence can masturbate out of necessity without posing a danger to themselves or society. But, the author states, this is not something that every man or woman can do: "Mais il est rare qu'on ne tombe pas

\footnotetext{
303 'C'est en ce sens que nous disons que la manustupration qui n'est point fréquente, qui n'est pas excitée par une imagination bouillante $\&$ voluptueuse, \& qui n'est enfin déterminée que par le besoin, n'est suivie d'aucun accident, \& n'est point un mal (en Médecine.) Bien plus, les anciens, juges trop peu séveres \& scrupuleux, pensoient que lorsqu on la contenoit dans ces bornes, on ne violoit pas les sois de la continence." Jean-Joseph Menuret de Chambaud (attributed), "Manstupration ou Manustupration [Médecine | Pathologie]," in The ARTFL Encyclopédie, vol. 10, p. 51.

304 “Aussi Galien ne fait pas difficulté d'avancer que cet infame cynique (Diogene) qui avoit l'impudence de recourir à cette honteuse pratique en présence des Athéniens, étoit très-chaste, quoad continentiam pertinet constantissimam; parce que, poursuit-il, il ne le faisoit que pour éviter les inconvéniens que peut entraîner la semence retenue." Menuret de Chambaud,"Manstupration," vol. 10, p. 51-52.
} 
dans l'excès. ${ }^{305}$ Therefore it is the excessive nature of the vice, and not necessarily the physical action itself, that is the root of its evil.

Tissot focuses on the medical problems associated with excessive masturbation, noting on many occasions how this horrible and destructive vice affects the mind and the senses. Like the Mesmerists in the next decades, Tissot makes the connection between imbalance in the animal fluids and lack of mental ability. If disease is the cause of intellectual feebleness among Mesmer's patients, for masturbators it is the self-inflicted consequence of their behavior. In a case involving an unnamed artisan, Tissot states that:

The disorder of his mind was equal to that of his body; devoid of ideas and memory, incapable of connecting two sentences, without reflection, without being afflicted at his fate ... Far below the brute creation, he was a spectacle ... and it was difficult to discover, that he had formerly made part of the human species. ${ }^{306}$

Both physically and mentally, then, the victim of his own passions loses his humanity. As the semen he promiscuously casts forth weakens his body, the phantasms he creates weaken his mind; an overuse of the imagination for the sake of voluptuous pleasure rendered the masturbator less human. Like a castrato on the stage or a performer in a tavern raree show, a spectacle in the original sense of the word, whose disordered nature, whose unnaturalness, was on display. ${ }^{307}$

Because of the nature of the subtle fluids which carry sensation and sentiment throughout the body, the health of the whole man is affected when he misuses his imagination. Loss of semen and weakness of both mind and body followed:

\footnotetext{
${ }^{305}$ Menuret de Chambaud, "Manstupration," vol. 10, p. 51-52.

${ }^{306}$ Samuel Auguste David Tissot, Onanism: or, a treatise upon the disorders produced by masturbation: or, the dangerous effects of secret and excessive venery. . . (London, 1766), 25. The English translation appears to be taken from the original Latin text, not the later French translation.

${ }^{307}$ From the Latin specere/spectare, "to look."
} 
The imagination, which having great influence on [the genitals], may, by being occupied with desires, put them in such a situation as serves reciprocally to excite them; and desire leads to act, which is the more pernicious in proportion as it is unnecessary. This organ of convenience is like all others, which are never properly actuated, but when nature stimulates them . . . we subject ourselves to want without being in want . . . it is imagination, habit, and not nature, that importune them. They drain nature both of that which is necessary, and also of that which she herself would have taken care to dispose of. ${ }^{308}$

Inappropriate use of the imagination, therefore, interferes with the operations of nature.

This unnecessary exercise drains the body of its necessary vital fluids. The masturbator becomes unable to do his dual duties to humanity: he is unable to produce children because his vice has left him barren and impotent, and he is unable to participate in society because he has lost his capacity for rational thought. In other words, his secret, unnatural habit has made him useless.

At first glance, it may seem strange that texts on masturbation mentioned the castrati, as their reproductive systems may not have allowed for the secret vice. However, as a cultural embodiment of unnatural otherness, castrati fit within the eighteenth-century medico-moral narrative surrounding masturbation just as it did the other suspect sexual practices. Tissot's anti-masturbation text mentions the castrati in several places, though for this particular physician, the appearance of the castrati merely served to illustrate a medical point. First, in Section VI entitled “The Importance of the Seminal Liquor" he cites Galen's theories on semen and puberty, stating the ancient physician "knew that humors were enriched by retained semen, though he was ignorant of its mechanism."309

\footnotetext{
308 Tissot, 73-74.

309 Tissot, 56.
} 
He then mentions eunuchs while attempting to explain this connection, stating that the absorption of semen into the blood causes the effects we associate with puberty such as the deepening of the voice and growth of hair on the face and body. Tissot proves his point with the following reasoning, that we can prove that semen is responsible for puberty by observing that eunuchs castrated before puberty, whose bodies do not contain the generative seed, do not undergo these changes. Next, the physician poses an interesting question: are eunuchs, then, less likely to succumb to what Tissot calls "venereal debauches?" 310 He provides an answer at the end of the next section, "An Examination of the Circumstances which accompany Emission":

There are two very different reasons. The first is, if they are unsusceptible of the advantages which are produced by the absorption of this liquor [semen], on the other hand, they do not lose that precious part of the blood which is destined for seed. They are not subject to those alterations which are occasioned by the prepared semen, which are specified above; nor can they be exposed to the disorders which arise from the privations of this humor unprepared. ${ }^{311}$

He separates what he calls semen in potentia, which modern medicine might equate with seminal fluid, from semen in actu, or sperm, which castrated bodies do not produce. He then pronounces:

If the first is not separated, the machine will be deficient of those succors which it derives from the prepared semen, without the changes which thereon depend: but this will no way impoverish it; for if it acquires nothing, it loses nothing; it remains in a state of infancy. When the semen is secerned and evacuated, then a privation, a real impoverishment, ensues. ${ }^{312}$

\footnotetext{
310 Tissot, 57.

311 Tissot, 70.

312 Tissot, 70-71.
} 
In other words, Tissot is envoking the idea of the economy of fluids, or the theory of balancing the amount and type of fluids within the body. Because the castrated body does not produce true semen, it loses nothing from the blood.

The second reason Tissot believes that eunuchs do not masturbate is fairly straightforward: "The second reason is, that eunuchs are not subject to spasms, to which I attribute a great part of these excesses." ${ }^{313}$ Tissot believes that castrated bodies cannot achieve orgasm, and therefore disregards any sexual desire on their part completely. This certainly flies in the face of popular theories and opinions on the castrati's sexuality, and at face value appears to be judgment-free compared to other medical, moral, and philosophical texts. Then, a footnote: "Those who are desirous of reading a very excellent production upon those imperfect men should peruse Witnof de castratis." ${ }^{314}$ One can hope that Tissot is displaying more compassion for these men than he does for those who have fallen victim to the pernicious disease of onanism.

Laqueur and others have written about the role of pleasure in eighteenth-century society. Historian Alexander Cook has looked at the growing trend of understanding pleasure as a legitimate pursuit of happiness during this period. ${ }^{315}$ By defining the concept of pleasure, eighteenth-century artists and philosophers separated 'legitimate' pleasures from the 'illegitimate' ones, into what Cook calls a "hierarchy" of pleasure. One of the most significant points in this taxonomic enterprise revolved around whether or not a pleasure was natural, an idea that permeated nearly all scientific and

\footnotetext{
313 Tissot, 71.

${ }^{314}$ Tissot, 57.

${ }^{315}$ Alexander Cook, 452.
} 
philosophical discourses of Enlightenment. ${ }^{316}$ For some philosophes, Cook states, the "distinction between the natural and artificial pleasures related to the progress of civilization. ${ }^{317}$ While historians have usually connected this to the rise of luxury goods and consumer culture in this period, it is applicable to the subjects covered here as well. Masturbation was considered an unnatural vice. It did nothing for humanity as a whole, and it destroyed the lives of those who had the misfortune to fall prey to its pleasures. In this way, we can draw a direct line from the unnatural sensual pleasures - both aural and sexual — offered by the castrati to the broader concerns over natural and legitimate sexual expression on the one hand, and unnatural, illegitimate ones on the other.

As a private pleasure, masturbation was also a misuse of something that could actively aid the public if properly harnessed: the imagination. At a time in which new economic activities and intellectual freedoms abounded, this sexual vice turned the Enlightenment constructs of liberty and privacy into a grotesque caricature of 'enlightened' virtues. ${ }^{318}$ Critics warned that masturbation was dangerous for the human body and the body politic because it rendered its perpetrator-victim inutile. Likewise, the castrati could both inflame the imaginings of deviant sexual desires and fulfill them in real life. As with schoolchildren and servants who spread knowledge of dangerous sexual habits, castrato sexuality was contagious.

Unlike the degenerate chronic masturbator, though, the castrato's body served a very specific, if unusual purpose: it could create sounds so intense, so powerful, and so beautiful that it brought grown men to tears and caused women to faint in ecstasy. So,

\footnotetext{
${ }^{316}$ Cook, 457.

${ }^{317}$ Cook, 457.

${ }^{318}$ Laqueur, Solitary Sex, 277.
} 
were the castrati inutile? From a biological, medico-moral perspective, the castrati had no positive, natural use. As lovers and as artists, the artificiality of the castrati could only create unnatural pleasures. Those who listened to the incredible power of male soprano voice might be drawn into vice; the lover most certainly would be. 


\section{Conclusion}

\section{The Embodiment of an Era}

Hidden neatly away within the Encyclopédie article on Taste, Montesquieu offered this enticing tidbit:

On Sensibilité. Almost always, things please and displease us in different respects: for example, the virtuosi of Italy give us little pleasure; $1^{\circ}$. because it is no wonder that accommodated as they are, they sing well; they are like an instrument from which the worker has cut wood to produce sounds. $2^{\circ}$. Because the passions they play are too suspicious of falsity. $3^{\circ}$. Because they are neither the sex we love, nor the one we esteem; on the other hand, they may please us, because they preserve for a very long time an air of youth, and moreover because they have a flexible voice which is particular to them; thus each thing gives us a feeling, which is composed of many others, which weaken and sometimes shock each other. ${ }^{319}$

This is, perhaps, the most succinct description of France's difficult relationship with the castrati. Obliquely referencing their disfigurement, he carefully notes that they-like a flute or a viol, or the reeds of a woodwind — are a man-made instrument, created with delicate, careful knifework. Neither a woman to be loved, or a man to be esteemed, the castrato emotes no natural passion as he is unnatural himself. And yet, that particular

\footnotetext{
319 "De la sensibilité. Presque toûjours les choses nous plaisent \& déplaisent à différens égards : par exemple les virtuosi d'Italie nous doivent faire peu de plaisir ; $1^{\circ}$. parce qu'il n'est pas étonnant qu'accommodés comme ils sont, ils chantent bien; ils sont comme un instrument dont l'ouvrier a retranché du bois pour lui faire produire des sons. $2^{\circ}$. Parce que les passions qu'ils jouent sont trop suspectes de fausseté. $3^{\circ}$. Parce qu'ils ne sont ni du sexe que nous aimons, ni de celui que nous estimons; d'un autre côté ils peuvent nous plaire, parce qu'ils conservent très long-tems un air de jeunesse, $\&$ de plus parce qu'ils ont une voix flexible \& qui leur est particuliere ; ainsi chaque chose nous donne un sentiment, qui est composé de beaucoup d'autres, lesquels s'affoiblissent \& se choquent quelquefois." Charles le Secondat, Baron de Montesquieu, "Goût," in The ARTFL Encyclopédie, vol. 7, p. 765. While Voltaire is the official author of the entry, the editors included the incomplete article Montesquieu was working on when he died. They justify the decision by stating: "l'auteur n'a pas eu le tems d'y mettre la derniere main; mais les premieres pensées des grands maitres méritent d'être conservées à la postérité, comme les esquisses des grands peintres." "Goût," vol. 7, p. 762.
} 
voice evokes feelings that are too strong to be ignored. A mixed emotion, then, of pleasure and disgust, love and derision, truly showcases the complexity of sensibility in eighteenth-century society.

So. Why castrati?

The castrati were a living paradox, a mirror of social and scientific concerns. They were not natural, but had a nature unto themselves in the eyes of the public. They elicited unnatural, larger-than-life emotions from their audience. They were seen as playthings of the effeminate aristocrats and dangerous libertines who seduced women. They were simultaneously objects of derision, pity, awe, and desire. As a part of the relationship between music and the physiological mechanics of feeling, their bodies served as a cultural lightning rod amid the stormy debates on humanness and naturalness that roiled throughout the Enlightenment era. Castrati were examples of the way in which disparate bodies experienced feelings in different ways; as Italians as well as 'effeminate' men, they were doubly Other to the philosophes who debated the merits of French versus Italian opera. They play only a bit part in the drama of the Querelle des Bouffons, but like any good supporting character, their role is unforgettable.

History has left no exact record of how many castrati were created to grace the operatic stages of Europe, but their number was likely quite small. However, as the first bona fide superstars of the modern western world, their lives, loves, and scandals were a constant source of entertainment for the public. While the castrati were a minority, the plethora of plays, newspaper reports, poetry, and satires that laud and degrade them show that these enigmatic men were indices of contemporary socio-cultural concerns. Because of their high-profile status, their classification as abnormal, unnatural, captivating man- 
made creatures made them an integral part of the discourse on what constituted human nature in the long eighteenth century. 
Primary Bibliography

Adams, George. An Essay on Electricity, Explaining the Theory and Practice of That Useful Science: And the Mode of Applying It to Medical Purposes. With an Essay on Magnetism. Printed by R. Hindmarsh for the Author, 1787. Gale Group, digital facsimile.

d'Alembert, Jean Le Rond. "Castrati [Histoire moderne].” The ARTF Encyclopédie.Vol. 2, p.756.

Ancillon, Charles. Italian love: Or, Eunuchism displayed . . Second Edition. London: M.DCC.XL [1740]. Eighteenth Century Collections Online, digital facsimile.

d'Aumont, Arnulphe. "Eunuque [Histoire ancienne | Histoire moderne | Médecine]." The ARTFL Encyclopédie. Vol. 6, pp. 158-61.

Burke, Edmund. A philosophical enquiry into the origin of our ideas of the sublime and beautiful. Second Edition. London: MDCCLIX. [1759]. Gale Group, digital facsimile.

Burney, Charles. The present state of music in France and Italy: Or, the journal of a tour through those countries, undertaken to collect materials for a general history of music. Second Edition. London: 1773. Gale Group, digital facsimile.

Buffon, Georges Louis Leclerc, comte de. Buffon's Natural history, abridged. Including the history of the elements, the earth, and its component parts, Mountains, Rivers, Seas, Winds, Whirlwinds, Waterspouts, Volcanoes, Earthquakes, Of Man, Quadrupeds, Birds, Fishes, Shell-Fish, Lizards, And Serpents; With A General View Of The Insect World. Illustrated with a great variety of copper-plates, elegantly engraved. London: M.DCC.XCI [1791]. Eighteenth Century Collections Online, digital facsimile.

de Cahusac, Louis. “Chanteur, euse [Musicien].” The ARTFL Encyclopédie. Vol. 3, p. 145.

Casanova, Giacomo. History of My Life. Translated by William R. Trask. Introduction by John Julius Norwich. New York: Everyman's Library (Alfred A. Knopf), 2007.

Diderot, Denis and Jean le Rond d'Alembert, eds. Encyclopédie, ou dictionnaire raisonné des sciences, des arts et des métiers, etc., University of Chicago: ARTFL

Encyclopédie Project (Autumn 2017 Edition). Edited by Robert Morrissey and Glenn Roe. http://encyclopedie.uchicago.edu/. 
-------. Rameau's Nephew and D'Alembert's Dream. Translated with introductions by Leonard Tancock. New York: Penguin Books, 1966.

Douglas, G. Archibald. The nature and causes of impotence in men, and barrenness in women, explained ... Third Edition. Dublin: M.DCC.LVIII. [1758]. Eighteenth Century Collections Online, digital facsimile.

Formey, Jean-Henri-Samuel. "Monstre [Zoologie]." The ARTFL Encyclopédie. Vol. 10, pp. 671-72.

Fouquet, Henri . "Sensibilite, Sentiment [Médecine]." The ARTFL Encyclopédie. Vol. 15 , pp. 38-52.

Hay, William. Deformity: An Essay. London: Printed for R. and J. Dodsley in Pall-Mall, and Sold by M. Cooper in Paternoster Row, MDCCLIV [1754]. Eighteenth Century Collections Online, digital facsimile.

de Jaucourt, Louis. "Difformité [Médecine].” The ARTFL Encyclopédie. Vol. 4, p. 990.

-------. "Jeu de la nature [Anatomie | Physiologie].” The ARTFL Encyclopédie. Vol. 8, pp. 532-35.

-------. "Monstre [Botanique]." The ARTFL Encyclopédie. Vol. 10, p. 671.

-------. "Prodige physique [Histoire des prodiges des anciens]." The ARTFL

Encyclopédie. Vol. 13, pp. 422-23.

-------. “Opera [Belles-Lettres].” The ARTFL Encyclopédie. Vol. 11, pp. 494-95.

-------.. “Opéra Italien [Spectacle moderne].” The ARTFL Encyclopédie. Vol. 11, p. 496.

Lallement, Jean Baptiste Joseph. Essai sur le mécanisme des passions en général. Paris:

Chez Pierre-Alexandre Le Prieur, 1751. Gale Group, digital facsimile.

Le Cat, Claude-Nicholas. A Physical Essay on the Senses, Translated from the French of M. Le Cat. London: R. Griffiths, 1750. Google books, digital facsimile.

Le Monnier, Louis-Guillaume. "Electricite [Physique]." The ARTFL Encyclopédie. Vol. 5, pp. 469-74.

Maupertius, Pierre-Louis Moreau de. The Earthly Venus. Translated by George Boas. New York: Johnson Reprint Corporation, 1966.

Menuret de Chambaud, Jean-Joseph (attributed). "Manstupration ou Manustupration [Médecine | Pathologie].” The ARTFL Encyclopédie. Vol. 10, pp. 51-54. 
Mesmer, Franz Anton. Mesmer's aphorisms and instructions, by M. Caullet de Veaumore, London, 1785. Gale Group, digital facsimile.

Montesquieu, Charles de Secondat. The Spirit of the Laws. Translated by Anne M. Cohler, Basia Carolyn Miller, and Harold Samuel Stone. Cambridge: Cambridge University Press, 1989.

Onania; or, the heinous sin of self-pollution . . . Fourth Edition. London: 1718. Gale Group, digital facsimile.

"Opéra Comique [Spectacle François].” Anonymous. The ARTFL Encyclopédie. Vol. 11, p. 495.

"Opéra des bamboches [Spectacle François].” Anonymous. The ARTFL Encyclopédie. Vol. 11, p. 495.

Roger, Joseph-Louis. Traite des Effects de la Musique sur le Corps Humain. Translated by Etienne Sainte-Marie. Paris: Chez Brunot, Librarie, Grenelle-St.-Honoré,1803. Google books, digital facsimile.

Rousseau, Jean-Jacques. "Dessus, \& en italien soprano [Musique]." The ARTFL Encyclopédie.Vol. 4, pp. 895-96.

Rousseau, Jean-Jacques. Essay on the Origin of Languages and Writings Related to Music. Translated and edited by John T. Scott. The Collected Writings of Rousseau, volume 7. Series editors Roger D. Masters and Christopher Kelly. Hanover: University Press of New England, 1998.

Tissot, S. A. D. (Samuel Auguste David). Onanism: Or, a Treatise upon the Disorders Produced by Masturbation: Or, the Dangerous Effects of Secret and Excessive Venery. Translated from the last Paris edition by A. Hume, M.D. London: 1767. Gale Group, digital facsimile.

Venel, Gabriel-François. "Climat [Médecine].” The ARTFL Encyclopédie. Vol. 3, pp. 534-36.

--------. “Infirmité [Grammaire | Médecine].” The ARTFL Encyclopédie. Vol. 8, p. 708.

Voltaire, François-Marie Arouet de, Charles-Louis de Secondat, baron de Montesquieu, Denis Diderot, and Jean Le Rond d'Alembert. "Goût." The ARTFL Encyclopédie. Vol. 7, pp. 761-70. 
Secondary Bibliography

Alano, Jomarie. "The Triumph of the Bouffons: La Serva Padrona at the Paris Opera, 1752-1754." French Review: Journal of the American Association of Teachers of French 79, no. 1 (2005): 124-35.

Arnold, R. J. Musical Debate and Political Culture in France, 1700-1830. Music in Society and Culture. Woodbridge: Boydell Press, 2017.

Berry, Helen. "Queering the History of Marriage: the Social Recognition of a Castrato Husband in Eighteenth-Century Britain." History Workshop Journal 74, (Autumn 2012): 27-50.

Cook, Alexander. "The Politics of Pleasure Talk in $18^{\text {th }}$-Century Europe." Sexualities 12, no. 4 (2009): 451-66.

Cowart, Georgia. The Triumph of Pleasure: Louis XIV \& the Politics of Spectacle. Chicago: University of Chicago Press, 2008.

Curran, Andrew. "Rethinking Race History: The Role of the Albino in the French Enlightenment Life Sciences." History and Theory 48, no. 3 (October 2009): 15179.

Curran, Andrew and Patrick Graille. "The Faces of Eighteenth-Century Monstrosity." Eighteenth-Century Life 21 no. 2 (1997): 1-15.

Daston, Lorraine and Katharine Park. Wonders and the Order of Nature. New York: Zone Books, 2001.

Dellamora, Richard, and Daniel Fischlin, Editors. The Work of Opera: Genre, Nationhood, and Sexual Difference. New York: Columbia University Press, 1997.

Dill, Charles William, Editor. Opera Remade, 1700-1750. Ashgate Library of Essays in Opera Studies. Farnham: Ashgate, 2010.

Douthwaite, Julia V. The Wild Girl, Natural Man, and the Monster: Dangerous Experiments in the Age of Enlightenment. Chicago: University of Chicago Press, 2002.

Emery, Ted. "Queer Casanova: Subversive Sexuality and the (Dis)embodied Subject in "History of My Life."' Italian Culture 24-25 (2006-2007): 23-44.

Feldman, Martha. The Castrato: Reflections on Natures and Kinds. Oakland, CA: University of California Press, 2015. 
------. Opera and Sovereignty: Transforming Myths in Eighteenth-century Italy. Chicago: University of Chicago Press, 2007.

Freitas, Roger. Portrait of a Castrato: Politics, Patronage, and Music in the Life of Atto Melani. New Perspectives in Music History and Criticism. Cambridge:

Cambridge University Press, 2009.

Fudge, Erica. At the Borders of the Human: Beasts, Bodies, and Natural Philosophy in the Early Modern Period. New York: Palgrave, 1999.

Garlington, Aubrey S., Jr. “'Le Merveilleux' and Operatic Reform in 18th-Century French Opera." The Musical Quarterly 49, no. 4 (Oct. 1963): 484-97.

Garraway, Dorris. "Race, Reproduction, and Family in Moreau de Saint-Méry's Description...de la partie française de l'isle Saint-Domingue." EighteenthCentury Studies 38, no. 2 (Winter 2005): 227-46.

Gilman, Sander L. Difference and Pathology: Stereotypes of Sexuality, Race, and Madness. Ithaca: Cornell University Press, 1985.

Gissis, Snait B. "Visualizing 'Race' in the Eighteenth Century." Historical Studies in the Natural Sciences 41, no. 1 (Winter 2011): 41-103.

Goodman, Dena. The Republic of Letters: A Cultural History of the French Enlightenment. Ithaca: Cornell University Press, 1994.

Goring, Paul. The Rhetoric of Sensibility in Eighteenth-century Culture. Cambridge: Cambridge University Press, 2005.

Grant, Kerry S. "Burney, Charles." Grove Music Online. Oxford Music Online. Oxford University Press.

Haggerty, George E. Men in Love: Masculinity and Sexuality in the Eighteenth Century. New York: Columbia University Press, 1999.

Harvey, Karen. "The Century of Sex? Gender, Bodies, and Sexuality in the Long Eighteenth Century." The Historical Journal 45, no. 4 (December 2002): 899916.

Heartz, Daniel. "Farinelli and Metastasio: Rival Twins of Public Favour." Early Music 12, no. 3: String Issue (August 1984): 358-66.

Heriot, Angus. The Castrati in Opera. New York: Da Capo Press, 1974. 
Higgins, Geoffrey. "Old Sluts and Dangerous Minuets: Or, the Underlying Musical Tensions of the Querelle Des Bouffons.” Eighteenth-Century Studies 45, no. 4 (2012): 549-63.

Hudson, Nicholas. 'From 'Nation' to 'Race': The Origin of Racial Classification in Eighteenth-Century Thought.” Eighteenth-Century Studies 29, no. 3 (Spring 1996): 247-64.

Huneman, Philippe. "Montpellier Vitalism and the Emergence of Aliensim in France (1750-1800): The Case of the Passions." Science in Context 21, no. 4 (2008): 61547.

Hurteau, Pierre. "Catholic Moral Discourse on Male Sodomy and Masturbation in the Seventeenth and Eighteenth Centuries." Journal of the History of Sexuality 4, no. 1 (July 1993): 1-26.

Jenkins, John S. "Mozart and the Castrati." The Musical Times 151, no. 1913 (Winter 2010): 55-68.

Johnson, James H. Listening in Paris: A Cultural History. Studies on the History of Society and Culture; v. 21. Berkeley: University of California Press, 1995.

-------. “The Encyclopedists and the Querelle Des Bouffons: Reason and the Enlightenment of Sentiment." Eighteenth-Century Life 10, no. 2 (1986): 12-27.

Johnson, Paul F. "Philosophe." The Oxford Companion to Philosophy. Edited by Ted Honderich. Second Edition. Oxford: Oxford University Press, 2005.

Kafker, Frank A., and Serena L. Kafker. The Encyclopedists as Individuals: A Biographical Dictionary of the Authors of the Encyclopédie. Oxford: Voltaire Foundation, 1988.

King, Thomas A. “The Castrato's Castration.” Studies in English Literature, 1500-1900 46, no. 3, [Restoration and Eighteenth Century] (Summer 2006): 563-83.

Kors, Alan Charles. D'Holbach's Coterie: An Enlightenment in Paris. Princeton: Princeton University Press, 1976.

Koschorke, Albrecht. "Physiological Self-Regulation: The Eighteenth-Century Modernization of the Human Body." MLN, 123, no. 3 [German Issue: Selbstregulierung als Provokation] (April 2008): 469-84.

Krimmer, Elizabeth. "'Eviva il Coltello'? The Castrato Singer in Eighteenth-Century German Literature and Culture." PMLA 120, no. 5 (October 2005): 1543-59. 
Kumar, Peeyush et al. "Male hypogonadism: Symptoms and treatment." Journal of Advanced Pharmaceutical Technology \& Research 1, no. 3 (2010): 297-301.

Laqueur, Thomas W. Making Sex: Body and Gender from the Greeks to Freud. Cambridge: Harvard University Press, 1990.

-------. Solitary Sex: A Cultural History of Masturbation. New York: Zone Books, 2003.

Lynn, Michael. Popular Science and Public Opinion in Eighteenth-Century France. Manchester: Manchester University Press, 2006.

McFadzean, A. J. S. “A Eunuch Takes the Gout.” The British Medical Journal 1, no. 5441 (1965): 1038-39.

Milner, Anthony. "The Sacred Capons.” The Musical Times 114, no. 1561 (March 1973): $250-52$.

Moscoso, Javier. "Monsters as Evidence: The Uses of the Abnormal Body during the Eighteenth Century." Journal of the History of Biology 31, no. 3 (Autumn 1998): $355-82$.

Mounsey, Chris. The Idea of Disability in the Eighteenth Century. Transits (Bucknell University). Lanham: Bucknell University Press, 2014.

Nelson, William Max. "Making Men: Enlightenment Ideas of Racial Engineering." American Historical Review 115, no. 5 (December 2010): 1364-94.

Norwich, John Julius. Introduction to History of My Life by Giacomo Casanova. Translated by William R. Trask, ix-xxii. New York: Everyman's Library (Alfred A. Knopf), 2007.

Nussbaum, Felicity. The Limits of the Human: Fictions of Anomaly, Race, and Gender in the Long Eighteenth Century. Cambridge: Cambridge University Press, 2003.

Outram, Dorinda. The Enlightenment. Cambridge: Cambridge University Press, 2005.

Paul, Charles B. "Music and Ideology: Rameau, Rousseau, and 1789." Journal of the History of Ideas 32, no. 3 (July-September 1971): 395-410.

Pekacz, Jolanta T. "Gender as a Political Orientation: Parisian Salonnières and the 'Querelle de Bouffons."' Canadian Journal of History 32, no. 3 (December 1997): 405-11. 
-------. "The Salonnières and the Philosophes in Old Regime France: The Authority of Aesthetic Judgement." Journal of the History of Ideas 60, no. 2 (April 1999): 27797.

Peschel, Enid Rhodes, and Richard E. Peschel. "Medical Insights into the Castrati in Opera." American Scientist 75, no. 6 (November-December 1987): 578-83.

Pinch, Adela. Strange Fits of Passion: Epistemologies of Emotion, Hume to Austen. Stanford: Stanford University Press, 1996.

Pinto-Correia, Clara, and João Lourenço Montiero. "Science in Support of Racial Mixture: Charles-Augustin Vandermonde's Enlightenment Program for Improving the Health and Beauty of the Human Species." Endeavour 38, no. 1 (2013): 19-26.

Prest, Julia. "In Chapel, on Stage, and in the Bedroom: French Responses to the Italian Castrato." Seventeenth-Century French Studies 32, no. 2 (2010): 152-64.

Reill, Peter Hans. Vitalizing Nature in the Enlightenment. Berkeley: University of California Press, 2005.

Riskin, Jessica. Science in the Age of Sensibility: The Sentimental Empiricists of the French Enlightenment. Chicago: University of Chicago Press, 2002.

Rogers, Francis. “The Male Soprano.” The Musical Quarterly 5, no. 3 (July 1919): 41325.

Rosselli, John. "From Princely Service to the Open Market: Singers of Italian Opera and their Patrons, 1600-1850." Cambridge Opera Journal 1, no. 1 (March 1989): 132 .

------. "The Castrati as a Professional Group and a Social Phenomenon, 1550-1850." Acta Musicologica, 60, no. 2, (May-August 1988): 143-79.

Rousseau, G.S., and Roy Porter, editors. Sexual Underworlds of the Enlightenment. Chapel Hill: University of North Carolina Press, 1988.

Schiebinger, Londa. "The Anatomy of Difference: Race and Sex in Eighteenth-Century Science." Eighteenth-Century Studies 23, no. 4 [Special Issue: The Politics of Difference] (Summer 1990): 387-405.

Singy, Patrick. "Friction of the Genitals and Secularization of Morality." Journal of the History of Sexuality 12, no. 3 (July 2003): 345-64. 
Stengers, Jean, and Anne Van Ness. Mastubation: The History of a Great Terror. Translated by Katheryn A. Hoffman. New York: Palgrave, 2001.

Stephens, Elizabeth. Anatomy as Spectacle: Public Exhibitions of the Body from 1700 to the Present. Representations. Liverpool: Liverpool University Press, 2011.

Stevens, Blake. "Monologue Conflicts: The Terms of Operatic Criticism in Pierre Estève and Jean-Jacques Rousseau." The Journal of Musicology 29, no. 1 (Winter 2012): $1-43$.

Stolberg, Michael. "Self-Pollution, Moral Reform, and the Venereal Trade: Notes on the Sources and Historical Context of 'Onania' (1716)." Journal of the History of Sexuality 9, no. 1/2 (January-April 2000): 37-61.

Thiele, Rüdiger. "Maupertuis, Pierre-Louis Moreau de." In Encyclopedia of the Enlightenment. Edited by Alan Charles Kors. Oxford: Oxford University Press, 2002.

Thomas, Downing A. Aesthetics of Opera in the Ancien Régime, 1647-1785. Cambridge Studies in Opera. Cambridge: Cambridge University Press, 2002.

-------. "Rameau's Platée returns: A case of double identity in the Querelle des bouffons." Cambridge Opera Journal 18, no. 1 (2006): 1-19.

Turner, David M. and Alun Withey. "Technologies of the Body: Polite Consumption and the Correction of Deformity in Eighteenth-Century England." Journal of the Historical Association 99 no. 338 (December 2014): 775-96.

Verba, Cynthia. Music and the French Enlightenment: Rameau and the Philosophes in Dialogue. Second edition. Oxford: Oxford University Press, 2017.

Vila, Anne C. Enlightenment and Pathology: Sensibility in the Literature and Medicine of Eighteenth-Century France. Baltimore: Johns Hopkins University Press, 1998.

Warren, Carol A.B. "Gender Reassignment Surgery in the 18th Century: A Case Study." Sexualities 17, no. 7 (2014): 872-84.

Weber, William. "Learned and General Musical Taste in Eighteenth-Century France." Past \& Present 89 (Nov. 1980): 58-85.

Wellman, Kathleen. "Physicians and Philosophes: Physiology and Sexual Morality in the French Enlightenment." Eighteenth-Century Studies 35, No. 2 (Winter, 2002): 267-77. 
Williams, Elizabeth A. A Cultural History of Medical Vitalism in Enlightenment Montpellier. History of Medicine in Context. Burlington, VT: Ashgate, 2003.

Wilson, Phillip K. 'Eighteenth-Century 'Monsters' and Nineteenth-Century 'Freaks': Reading the Maternally Marked Child." Literature and Medicine 21, no. 1 (Spring 2002): $1-25$. 